\title{
WestVirginiaUniversity
}

THE RESEARCH REPOSITORY @ WVU

Graduate Theses, Dissertations, and Problem Reports

2009

\section{Soldiers and stereotypes: Mountaineers, cultural identity, and World War II}

C. Belmont Keeney

West Virginia University

Follow this and additional works at: https://researchrepository.wvu.edu/etd

\section{Recommended Citation}

Keeney, C. Belmont, "Soldiers and stereotypes: Mountaineers, cultural identity, and World War II" (2009). Graduate Theses, Dissertations, and Problem Reports. 2936.

https://researchrepository.wvu.edu/etd/2936

This Dissertation is protected by copyright and/or related rights. It has been brought to you by the The Research Repository @ WVU with permission from the rights-holder(s). You are free to use this Dissertation in any way that is permitted by the copyright and related rights legislation that applies to your use. For other uses you must obtain permission from the rights-holder(s) directly, unless additional rights are indicated by a Creative Commons license in the record and/ or on the work itself. This Dissertation has been accepted for inclusion in WVU Graduate Theses, Dissertations, and Problem Reports collection by an authorized administrator of The Research Repository @ WVU.

For more information, please contact researchrepository@mail.wvu.edu. 
Soldiers and Stereotypes:

Mountaineers, Cultural Identity, and World War II
C. Belmont Keeney

Dissertation submitted to the Eberly College of Arts and Sciences

at West Virginia University

in partial fulfillment of the requirements

for the degree of

Doctor of Philosophy

in

History
Ronald L. Lewis, Ph.D., Chair
Katherine Aaslestad, Ph.D.
Elizabeth Fones-Wolf, Ph.D.
Kenneth Fones-Wolf, Ph.D.
Frances Hensley, Ph.D.

Department of History

Morgantown, West Virginia

2009

Keywords: Appalachia, World War II, Soldiers, West Virginia, Cultural Identity, Stereotypes, Mountaineers, Combat 


\title{
ABSTRACT \\ SOLDIERS AND STEREOTYPES: MOUNTAINEERS, CULTURAL IDENTITY, AND WORLD WAR II
}

\author{
C. BELMONT KEENEY
}

To what extent are Appalachian stereotypes true and how much is pure fabrication? This study seeks to answer this question by examining the experiences of West Virginia soldiers during World War II. Appalachian hillbillies, believed to be culturally backward, uncivilized, isolated, and prone to violence, were often sent straight to the infantry because it was believed that their wild mountain heritage made them inherently better fighters. Using interviews, letters, and a collection of over 1,200 firsthand written accounts of Appalachian veterans collected by West Virginia University in 1946, this study traces the evolution of the cultural and individual identities of mountaineers throughout their time in the United States military. These West Virginia narratives are also compared and contrasted with those of other soldiers in the United States and around the world. Because every single ethnicity and race in the world fought and was exposed to many similar circumstances, the war itself is the ultimate litmus test for the validity of cultural stereotypes. If stereotypes associated with Appalachians are true, then their wartime narratives will reflect different reactions to soldiering and war based on their own inherent cultural traits. If not, then their reactions to war will be similar to those of other soldiers from different regions and nations. This study endeavors to demonstrate what the Second World War reveals about the changing identity of West Virginia soldiers, and more specifically, the culture and stereotypes associated with them. 
For my parents,

C.B. and Patsy Keeney 


\section{Acknowledgments}

Every scholar is the product of history because we each stand upon the shoulders of those who have come before. I am exceedingly grateful for the guidance of my committee. Ron Lewis has been indispensible in advising me and aiding in the development of my writing and research skills while simultaneously affording me the freedom to explore the ideas and subjects that are of great interest to me. The remainder of my committee, Ken Fones-Wolf, Elizabeth Fones-Wolf, Katherine Aaslestad, and Frances Hensley, has also helped me mold my arguments into sharper focus and clarity. A number of other friends and colleagues have also donated their time in order to read rough drafts and proofread texts. Among them are Mike Buseman, Jim DePalma, Amber DePalma, Amanda Cummings, and Polly Smith. I also wish to thank the staffs at the West Virginia and Regional History Collection at West Virginia University and the State Department of Archives and History in Charleston, West Virginia for their assistance in finding good primary sources. My students at West Virginia University should also be commended for interviewing numerous World War II veterans and preserving them, not only for my research, but for the West Virginia Veterans Project and for future generations. I would like to thank my parents for the example that they have set and for the faith that they have had in me. Lastly, I would like to thank God for giving me the abilities that I have and providing me the opportunity to reach my full potential as a scholar. 


\section{Table of Contents}

Acknowledgements............................................... iv

Introduction: From Humans to Stereotypes........................... 1

Chapter One: From Peace to War.................................. 23

Chapter Two: From Local to Appalachian................................ 54

Chapter Three: From Appalachians to Americans.......................... 99

Chapter Four: From Americans to Humans............................ 150

Conclusion: From Humans to Stereotypes............................. 199

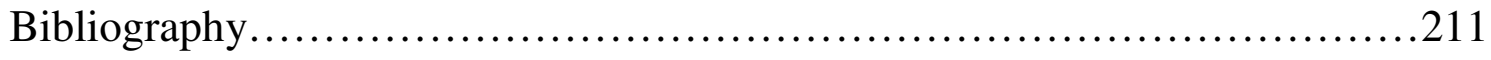


Introduction

\section{From Humans to Stereotypes}

In 1947, Dwight D. Eisenhower delivered a convocation address at West Virginia University before a crowd of approximately 18,000 students, faculty, and others at Mountaineer Field. One of the main themes of Eisenhower's speech centered around the contribution of West Virginia soldiers to the Allied victory in the Second World War. This contribution was aided, he said, by a longstanding cultural tradition:

The mountains have been the home of liberty. Among them men sought refuge from the despotism and pursued a way of life whose spiritual core was individual freedom. Mountaineers have ever been valiant defenders of liberty ... West Virginians, for more than two centuries, have enriched the mountain traditions and were urged on to great achievement by the spiritual heritage of the West Virginia mountains. . in our generation, you of this state have proved yourselves the spiritual heirs of the pioneers who saw, in the valleys of this region, paths to a more secure freedom and in its mountains a refuge for the oppressed. ${ }^{1}$

To the certain delight of the crowd, the famous general went on to praise the mountaineers for doing their duty in the Second World War. The language he used is, of course, familiar to anyone well-versed in Appalachian scholarship. Eisenhower embellished old stereotypes of the rugged, freedom loving mountaineer; characteristics which, inevitably made the mountaineer an effective player in Roosevelt's great Arsenal of Democracy. It is not the first time such

\footnotetext{
${ }^{1}$ Eisenhower Convocation Address, transcript, West Virginia and Regional History Collection, West Virginia University, Morgantown, West Virginia (hereafter cited as WVRHC).
} 
stereotypical features have been used to explain performance in combat from an Appalachian. In the First World War, Sergeant Alvin York, from the mountains of East Tennessee, became an American hero and legend because, according to media and military publicity, his wild mountain heritage enabled him to perform with great courage and distinction in Europe. Being Appalachian, it seems, makes one a better soldier. ${ }^{2}$

One of the cornerstones of the conceptualization of Appalachia as a distinct and exceptional culture is the idea of the inherently violent mountaineer. There are two versions of the mountain man in the American popular consciousness. First is the noble mountaineer, with his rugged individualism, braving the frontier to carve a land of freedom and opportunity out of the barren wilderness. The second is the hillbilly or redneck, isolated from the rest of society; backward, ignorant, and savage. A violent culture is the common characteristic of both of these caricatures of the Appalachian people. The noble mountaineer is violent because violence is simply a harsh fact of life on the frontier. The hillbilly is violent because he is clinging to a long-gone, uncivilized age (the frontier) in an increasingly civilized world. Historical examples of violence in Appalachia range from the Whisky Rebellion and the Greathouse Massacre in the revolutionary period to the HatfieldMcCoy Feud and the West Virginia Mine Wars of the late nineteenth and early twentieth century. Who can forget the famous pictures of William Anderson

\footnotetext{
${ }^{2}$ John Alexander Williams, Appalachia: A History (Chapel Hill: University of North Carolina Press, 2002), 221-223.
} 
"Devil Anse" Hatfield, with his long beard, jug of moonshine, and Civil War musket? Such an image is firmly imprinted in American popular culture as the embodiment of the Appalachian hillbilly. ${ }^{3}$ According to historians Allan Batteau and Henry Shapiro, these stereotypes were a literary creation of urban America during the Industrial Age that, among other things, provided an explanation to mainstream Americans for these violent episodes. Writers such as John Fox Jr., Mary Noailles Murfree, Berea College President William Goodell Frost, John C. Campbell, and a host of northern journalists wrote about the "strange and peculiar" culture found in the Appalachian Mountains. ${ }^{4}$ A key component to this culture was the violent nature of the mountain man himself. Or to put it in the words of a Progressive Era New York journalist, the Appalachians were a "murderland" where "violent savages threaten progress.",

According to the writers of the late nineteenth and early twentieth century, isolation was the key to the mountaineers' savage nature. Geographic isolation led to cultural isolation. Over time the isolation of the mountaineers became a catalyst for inherent cultural traits such as violence, laziness, backwardness, and a reluctance to modernize along with the rest of America. These ideas were not based on historical research, but rather, had their origin in works of fiction. In this

\footnotetext{
${ }^{3}$ Anthony Harkins, Hillbilly: A Cultural History of an American Icon (Oxford: Oxford University Press, 2004), 7-12.

${ }^{4}$ See Allan W. Batteau, The Invention of Appalachia (Tuscon, The University of Arizona Press, 1990); Henry D. Shapiro, Appalachia on Our Mind: The Southern Mountains and Mountaineers in the American Consciousness, 1870-1920 (Chapel Hill: University of North Carolina Press, 1978). For a good summary of the origins of the "invention" of Appalachia, see Williams, Appalachia: A History, 197-204.

${ }^{5}$ Quoted in Harkins, Hillbilly, 39.
} 
case, fiction proved to be more powerful than fact. Literary magazines published tales of an exotic culture somewhere in the hills of Appalachia. The idea of Appalachian "otherness" was accepted as fact by mainstream America and the cultural traits that fiction writers attributed to the region became perpetual stereotypes reinforced in American popular culture. As the years passed, other writers such as Horace Kephart, John C. Campbell, and Jack Weller failed to question the authenticity of the fiction writers and reinforced the beliefs in inherent traits, cultural isolation, and stereotypes in the region. Appalachians were not seen as individual humans, but as stereotypes. Throughout the twentieth century, the concept of violence as an cultural trait became a key component of transforming mountaineers from humans to stereotypes in the popular consciousness of the nation. ${ }^{6}$

In recent decades much scholarship has been published in order to refute these stereotypes. Altina Waller, Dwight Billings, Kathleen Blee, David Corbin, Ronald Lewis, and even my own writings have delved into the causes of violence during the industrial period of Appalachia. The overall consensus of recent Appalachian historical works has revolved around the idea that industrialization and modernization, with its competition for ownership and development of land and natural resources, led to the feuds and labor violence so prevalent in Appalachia between 1880 and 1932. Violence then, was not the result of the

\footnotetext{
${ }^{6}$ See Ronald L. Lewis and Dwight B. Billings, "Appalachian Culture and Economic Development," Jounral of Appalachian Studies (Spring 1997): 13-21.
} 
absence of modernity and industrialization, but rather, accompanied it. ${ }^{7}$ Thus, the idea of an inherently violent culture, created by journalists, politicians, and fiction writers of the Industrial Age does not reflect accurate history but rather served to give justification for the exploitation of Appalachians and the unchecked abuse of their land and resources. When Appalachians responded to such abuses by violently fighting back, the media did not see the harsh mining conditions, land theft, the mine guard system, and economic abuse as the cause. Rather, the violence took place, according to this perception, because there was something inherently wrong with the native mountaineers. Ironically, this cultural stereotype of the Industrial Age simultaneously celebrated the rugged toughness of the Anglo-Saxon conquest of the frontier in a time when millions of ethnic European immigrants threatened to unsettle the established perception of what it meant to be an American. ${ }^{8}$ These beliefs are only stereotypes, the Appalachian historians claim, not a reality.

\footnotetext{
${ }^{7}$ Among many other works see Altina Waller, Feud: Hatfields, McCoys, and Social Change in Appalachia (Chapel Hill: University of North Carolina Press, 1988); Dwight B. Billings and Kathleen M. Blee, The Road to Poverty: The Making of Wealth and Hardship in Appalachia, (Cambridge: Cambridge University Press, 2000); Ronald L. Lewis, Transforming the Appalachian Countryside: Railroads, Deforestation, and Social Change in Appalachia, 18801920 (Chapel Hill: University of North Carolina Press, 1998).

${ }^{8}$ Williams, Appalachia: A History, 201-202. "Mountain people were not just white, but the right kind of whites." In an age when southern and eastern Europeans were flushing into America by the millions, the notion of preserving traditional Anglo-Saxon culture became an obsession of some urban Americans. They believed they could find examples of an Anglo-Saxon culture unaltered by immigrants in Appalachia because of the isolation of the mountaineer. This belief led to the embellishment and preservation of folk arts, crafts, and mountain music because it was considered to be the culture of colonial America preserved in the Appalachian mountains. Also see, Jane S. Becker, Selling Tradition: Appalachia and the Construction of an American Folk, 1930-1940 (Chapel Hill: University of North Carolina Press, 1998).
} 
But stereotypes die hard, even in academia. A host of recent books and research, within and without the field of history, have continued to perpetuate the idea of a culture of violence in Appalachia and the mountain South. Former Secretary of the Navy James Webb published a popular book in 2005 portraying the modern Appalachian as born into a "culture of guns," resistant of civil authority, defiant, rebellious, violent and freedom loving. ${ }^{9}$ While Webb's portrayal leans towards the old, glorified mountaineer, other recent academic portrayals are not so kind. In 2006, Geneticists at the University of Pennsylvania and Dr. Nuzhet Atuk at the University of Virginia suggested that the violence in the Hatfield-McCoy Feud stem, at least on the McCoy side, from an inherited genetic disorder called Von Hippel-Lindau disease (VHL). Symptoms of the disease include high blood pressure, headaches, and violent tempers. Scientists at UVA and the University of Pennsylvania state that the genetic disease has been prevalent in the McCoy family for at least three generations and speculate that it could have led to feud violence in an earlier time. Predictably, media coverage of the study emphasized how the disease could be a scientific explanation for the violent behavior of Appalachians. ${ }^{10}$

And it doesn’t stop with geneticists. Psychologists Joseph A. Vandello and Dov Cohen, in the 2004 book The Psychological Foundations of Culture, ignore

\footnotetext{
${ }^{9}$ James Webb, Born Fighting: How the Scots-Irish Shaped America (New York: Broadway Press, 2005), 1-11.

${ }^{10}$ See Allan G. Breed, "VHL and the Hatfield and McCoys?" http://www.vhl.clinicahealth.com/comments.ph?sids07/04/06/1826223; Associated Press article, "Hatfield-McCoy Feud blamed on 'rage' disease," http://www.msnbc.com/id/17967965. For general information on the disease itself, see http://www.vhl.org.
} 
recent historical scholarship on violence in Appalachia and seek to explain its residual component in modern culture. ${ }^{11}$ In their psychological model, the violent culture of the mountain South has passed through four stages of development. In the Behavioral Stage, the experience on the colonial frontier resulted in the creation of violent cultural behavior as a functional reaction to the environment. A lack of law enforcement, isolation, livestock culture, and the rugged landscape made violence necessary for survival. In the Meaning Stage, these methods of survival developed into accepted behavioral patterns, such as feuds, vendettas, and taking the law into one's own hands because there was no organized law to which one could have turned. The problem, according to this psychoanalysis, occurs in the Internalized Stage, where "Environmental norms and frontier attitudes outlast the frontier that gave rise to them." 12 The result is a "cultural lag" - when "cultural adaptations that may have been functional at some point persist even when the conditions that gave rise to them are gone." In other words, when modernization and civilization arrive, the tradition of violence in the culture is so firmly embedded that it refuses to go away. ${ }^{13}$ Lastly, the Compliance Stage stumbles on to the present where violence continues to live in the culture because the people themselves, while internally questioning violent behavior, remain ignorant as to the historical roots of the violence and are afraid to stand up and contradict these

\footnotetext{
${ }^{11}$ Joseph A. Vandello and Dov Cohen, "When Believing is Seeing: Sustaining Norms of Violence in Cultures of Honor," The Psychological Foundations of Culture, Mark Schaller and Christian Camdall, eds., (London: Lawrence Erlbaum Associates, 2004): 281-301.

${ }^{12}$ Ibid., 283.

${ }^{13}$ Ibid., 285
} 
longstanding cultural norms. The theory uses very old historical data and, without bothering to establish the region as more violent, simply assumes the existence of a more violent culture in Southern Appalachia. ${ }^{14}$ To Appalachian historians, this analysis feels like it should be at least fifty years old. But solid or not, this kind of scholarship is still out there. At the very least, such scholarship by writers and scientists suggests the need for greater communication and collaboration across academic disciplines. Until that day arrives, it is readily evident that, despite three decades of Appalachian historical revisionism, the cultural stereotypes of the violent mountaineer are nowhere near being eliminated from scholarly work and the popular consciousness.

Allan Batteau, in his conclusion to The Invention of Appalachia, states that "the structure of the image of Appalachia embraces some of the central concerns of American identity." ${ }^{15}$ In other words, the stereotypes of the hillbilly and the mountaineer do not reveal anything definitive about Appalachians themselves, but rather, tell us something about American self-perception and identity. Or as John Williams chooses to put it, "If we need the example of the ignoble hillbilly to remind us of where we've been and what we could become, even more do we need the noble mountaineer. ... Appalachia lives on divided in our minds because we need it to." 16 This divided perception then results in, "a grand contest for the

\footnotetext{
${ }^{14}$ Ibid., 299-301.

${ }^{15}$ Batteau, The Invention of Appalachia, 197.

${ }^{16}$ Williams, Appalachia: A History, 398.
} 
definition of American civilization." ${ }^{17}$ If one takes these studies at face value then, Appalachian identity becomes really nothing more than a house of mirrors in which Americans can see distorted images of who they really are. One reflection touts the ideals of American rugged individualism and freedom, while another gives us the dangers of lawlessness, holding onto backward traditions, and the need for cultural progress.

While the works of Williams, Batteau, and Shapiro certainly carry significant weight and go a long way towards explaining the origins and survival of the violent mountain stereotype in America, I intend to take this interpretation a step further. A problem with the "Appalachian Invention" theory is that it limits what the violent stereotypes of mountaineers can tell us about cultural identity by only examining what these stereotypes tell us about America. What of the rest of the globe? Do similar stereotypes of mountaineers exist in other cultures, and, if so, does not a certain international unanimity of perception concerning mountain cultures tell us more about how all advanced civilizations see themselves as opposed to merely telling us something about American identity? I suggest that it does. Moreover, an understanding of some international perspectives of mountain violence, and the validity of such viewpoints, can go a long way in eliminating the origins and perpetuation of Appalachian stereotypes. Such elimination is long overdue. But, in order to understand what violent mountain stereotypes tell us about human civilization as a whole, and how this relates to the Second World

\footnotetext{
${ }^{17}$ Batteau, The Invention of Appalachia, 200.
} 
War, we must first look at international perceptions of mountaineers and what these perceptions share with Appalachian stereotypes.

\section{Stereotypes in Mountain Cultures: An International Perspective}

The resistance of the mountains to lowland influence has often been noted ... the observation could be confirmed anywhere where the population is so inadequate, thinly distributed, and widely dispersed as to prevent the establishment of the state, dominant languages, and important civilizations ... a study of the vendetta would lead one towards a similar conclusion. The countries where the vendetta was in force - and they were all mountainous countries - were those that had not been molded and penetrated by medieval concepts of feudal justice.... As we have seen, the mountains resist the march of history ... the history of mountains is checkered and difficult to trace ... [the mountain men] wears ragged cloth cloaks, their legs are wrapped in strips of material held in place with string crossgartered; their wild eyes peer from behind disordered black hair. ${ }^{18}$

The description above sounds as though it could have been written by

Frost, Fox, Caudell, or any of the other early writers on Appalachia. All the key elements are there. One can find references to isolation, backwardness, lack of civilization and government rule, independence, and of course, violence. But the description is not of Harlan County, Kentucky, nor of "Bloody" Mingo in the early twentieth century. The author is not John Fox Jr., nor is it a quote from Jack

\footnotetext{
${ }^{18}$ Fernand Braudel, The Mediterranean and the Mediterranean World in the Age of Phillip II, translated by Sian Reynolds, (New York: Harper and Row, 1972), 44-46. This book was expanded from Braudel's doctoral thesis which, interestingly enough, he began writing while he was a German POW in World War II.
} 
Weller's infamous Appalachian study, Yesterday's People. Instead, the passage above refers to the people who inhabited the mountainous regions of the Mediterranean world in the sixteenth century and the author is one of the most renowned historians of the twentieth century, Fernand Braudel. Despite the passage of four centuries and thousands of miles of separation, Braudel's description of the mountain culture of Sardinia makes it seem like Devil Anse Hatfield would feel right at home.

Braudel's analysis, one that championed the Annales version of historical study, stresses the role of geography and its imposition on the development (or lack thereof, as in the case of mountain communities) of culture over time. Without a doubt, geography plays an important role in history. There is reason behind why people build cities by rivers and generals, whenever possible, choose the high ground before a battle. A very quick and obvious example of the impact of geography on civilization is Ancient Egypt. One does not have to be an Egyptologist to see the significance that the Nile played in the prosperity, religion, and mythology of that civilization. When the Nile flooded regularly, enabling a steady and dependant agricultural production, it was an international bread basket and a center of enlightened culture for the ancient world. When the Nile stopped flooding regularly, the people stopped flourishing. As a result the old cultures and religions were swept away. ${ }^{19}$ Conversely, a potential problem with Appalachian

\footnotetext{
${ }^{19}$ Barry J. Kemp, Ancient Egypt: Anatomy of a Civilization (London: Routledge, 1989), 21-35. Kemp is also, it seems, an ardent supporter of the Annales school of historical interpretation and
} 
histories in recent years has been that historians, in a zealous effort to deconstruct and distance themselves from stereotypical manifestations (i.e., Appalachians were not isolated, they were not homogenous, they were not behind the times), have often, albeit inadvertently, diminished the prominent role of mountains on the culture of the Appalachian people. After all, long before Appalachia was an “invention," it was a mountain range.

Indeed, while attempting to articulate the reasons behind the violence in Appalachia, historians of recent years have focused their attention almost entirely on the Industrial Age. While much of this scholarship is very solid, the fact remains that the perception of the people of Appalachia as more violent than the rest of America predated the time when they were even called Appalachians. During the Revolutionary War, for example, a Hessian Captain blamed much of the rebellious violence on the frontiersmen of Appalachia, particularly the recently arrived Scotch-Irish, who had settled in western Pennsylvania, western Virginia, and elsewhere along the mountain range. "Call this war by whatever name you may," he wrote, "only call it not an American rebellion; it is nothing more or less than a Scotch-Irish Presbyterian Rebellion.. ${ }^{, 20}$ Another observer of the Revolutionary Period, Hector St. John de Crevecoeur, examined the Scotch-Irish of the Alleghenies and observed, "They love to drink and quarrel. They are heavily emphasizes the role of geography in the ideological development of the ancient Egyptian state.

${ }^{20}$ Quoted in Ron Chepesuik, The Scotch-Irish: From the North of Ireland to the Making of America (London: McFarland and Company, Inc., 2000), 1. 
litigious and soon take to the gun." ${ }^{21}$ Furthermore, contemporary British observers remarked that the Scotch-Irish of pre-revolutionary America left the settled coastline for the mountains for two main reasons. First, they felt more at home, dating back to their ancient Celtic heritage in the Scottish highlands. Second, they were trying to escape British authority. Thus, the early settlers of Appalachia, so it was believed, already exhibited characteristics attributed to them much later by writers of the late nineteenth and early twentieth century - the supposed "inventors" of Appalachia. Even as early as the Revolutionary War, mountaineers in the colonies were seen as more violent, choosing isolation over civilization, and obviously, they loved their freedom. Why? According to contemporaries, it was because the settlers held on to longstanding cultural traditions that began in the Scottish highlands. ${ }^{22}$

Whether or not this perception is accurate is not yet the point. But there are two conclusions that one may quickly draw. The first of which is that the perception of early settlers of Appalachia as violent evolved too rapidly for the Appalachian mountains themselves to impose a tradition of violence on the inhabitants. In the minds of many people in the American Colonies, the ScotchIrish, who were the first European group to settle the region en masse, were already violent and uncivilized when they arrived. David Hackett Fischer's exhaustive study of British folkways in America, Albion's Seed reiterates this

${ }^{21}$ Patrick Griffin, The People with no Name: Ireland's Ulster Scots, America's Scotch-Irish, and the Creation of a British Atlantic World, 1689-1764 (Princeton: Princeton University Press, 2001) 2 .

${ }^{22}$ Ibid., 112-121; Michael Fry, The Scottish Empire (Edinburgh: Tuckwell Press, 2001), 15-17. 
point. The early settlers of the Appalachians were typically seen as violent, barbaric, and ungovernable. Furthermore, the Scotch-Irish as a whole, were often called the "scum of two nations." 23 The second conclusion is that this perception of Appalachian violence does not originate with urban America during the Industrial Age as they looked to a feuding and labor-troubled region, but with British and colonial observers and their own traditional stereotypes of the Scottish Highlanders. ${ }^{24}$ Simply put, the perception of violent Appalachia has international roots.

These international roots sprang from the British, and even a general European, view of the Scots. Even though most of the early settlers of Appalachia were not actually Scottish, but rather, Scotch-Irish, it was presumed that Scottish characteristics left a strong imprint on the region's culture. Grant Simpson elaborates on this international perception in The Scottish Soldier Abroad by stating that, "Scots have a historical and international reputation as renowned fighters - barbarous and remote. Scotsmen served very prominently in the British

\footnotetext{
${ }^{23}$ David Hackett Fischer, Albion's Seed: Four British Folkways in America (Oxford: Oxford University Press, 1991), 612-614.

${ }^{24}$ Batteau and Shapiro would probably respond to this claim by asserting that even though the perception of a violent region existed before the Industrial Age, it did not become a part of American popular consciousness until that time. Possibly. But as the rest of this study will demonstrate, the stereotype of the violent mountaineer is not an American perception at all, but a global one. Violence in mountain cultures was already a part of the British popular consciousness by the colonial era. This damages, though it does not destroy, the claim of how Appalachian stereotypes reflect modern American identity and mythology. I still think there is some validity to this argument. But this old argument is, by no means, complete and without its flaws. John Williams does at least mention Braudel's observations of mountain cultures, but Williams uses it only to demonstrate that wherever mountain and lowland cultures intersect, "city folks always control the media." Williams does not pursue this into a global interpretation. See Williams, Appalachia: A History, 145.
} 
Empire and as mercenaries in France, Russia, America, and Africa." ${ }^{25}$ They served so prominently, in fact, that a common European saying went, "Rats, lice, and Scotsmen. You find them the world over." ${ }^{26}$ The highlanders were noted by the British as being clannish, with "warlike manners, freedom loving, and rugged."27 Because British policymakers believed, or saw potential benefit from, these stereotypes, they purposely recruited highlanders for military duty in the formation of their worldwide empire. Heather Streets' well-researched book, Martial Races: The Military, Race, and Masculinity in British Culture, 1857-1914, demonstrates how the Scottish highlanders were specific targets of army recruits, serving in elite regiments and even wearing special uniforms. But the British did not stop there. If people from the mountains of Scotland were better fighters, why not recruit fighters from other remote, mountainous regions? And so they did; finding and recruiting members of the Gurkhas tribes from the Himalayas in Nepal because of their reputation as fierce warriors. In what Streets calls a "Martial Race Ideology," the British filled their ranks with men from rugged cultures in order to build their powerful empire. Very often, these rugged folk came from mountain regions. ${ }^{28}$

\footnotetext{
${ }^{25}$ Grant G. Simpson, ed., The Scottish Soldier Abroad, 1247-1967 (Edinburgh: Billings and Sons, 1992), vii. as numbers in the Scottish Highlands dwindled, the British recruited heavily from the Scottish Lowlands, but continued to call them highlanders in order to keep up the reputation that their ranks were filled with mountain men.
} 
There are other examples. One can find an almost identical parallel between the mainstream American portrayal of the Appalachian and the Russian portrayal of the Chechen. For over three centuries, the region of Chechnya, in the Northern Caucasus Mountains, has been a hotbed of violence and resistance to Russian rule, and the Russians have had a tendency to look none too favorably on their southern neighbors. Gortsy is the Russian word for mountaineer and they use it in reference to the Chechan. Once again, the gortsy could very well be from Eastern Kentucky. They are defined by Russian anthropologists as having three defining characteristics: 1) they are a herding society and self-sufficient 2) they are a clannish society with "extreme vigilance over one's freedom and the strong rejection of any authority external to the kin group" 3) they are raised to be warriors, with blood feuds (in the Russian, kanly) acting as a common and reoccurring aspect of their mountain lives. ${ }^{29}$ This mountain region has been marked with constant rebellion which has endured to the present day. During the Second World War, Chechan freedom fighter Hasan Israilov led a revolt against the Soviets. Some of his men even left the Caucasus Mountains to fight alongside the Germans during the Crimean offensive in 1942. Unfortunately for Israilov, he was assassinated and his revolt was mercilessly crushed by Stalin. ${ }^{30}$

With an international view of mountain cultures, it is impossible to see Appalachian identity in the same light. No longer confined to Appalachia, we now

\footnotetext{
${ }^{29}$ Moshe Gammer, The Lone Wolf and the Bear: Three Centuries of Chechen Defiance of Russian Rule (Pittsburgh: University of Pittsburgh Press, 2006), 4-5.

${ }^{30}$ Ibid., 158-164.
} 
see that the idea of a rugged, violent, isolated, and independent mountaineer exists in Scotland, Nepal, Chechnya, and even Sardinia. The perception spans continents and centuries. Certainly there are going to be slight regional variations of the mountain stereotypes, but the similarities are too great to ignore. In this light, the current viewpoint of the creation of the Appalachian mountaineer as defined by Batteau, Williams, Shapiro, and others is incomplete. One can no longer say that this stereotype is merely an Appalachian or even an American phenomenon. It is worldwide. Therefore, the stereotype that Batteau asserts is a "grand contest for the definition of American civilization" now becomes something much more. This stereotype is now about how more modernized cultures (Britain, Urban America, Czarist and Soviet Russia, and even early modern Mediterranean) portray the mountain people around them. The consensus seems unanimous among all these different cultures. Does this mean that psychologists Vandello and Cohen are correct and there is a "cultural lag" that is embedded in the mountain man, making him more inherently violent? Furthermore, if the perception of mountain people as inherently violent is a phenomenon found in multiple places around the world, surely everyone cannot be mistaken in their portrayals, can they? Surely there must be some element of truth to the assertions?

This question, at long last, brings us to West Virginia soldiers and World War II. The Second World War was the most violent event in the history of the world, killing at least forty million people. All around the globe, human beings fought and slaughtered one another on a scale that has never been approached and, 
hopefully, never again will be. While figures for all of Appalachia are unknown, we do know that 218,665 West Virginians served in the military during World War II and 5,830 of them lost their lives. ${ }^{31}$ As they served they wrote letters to their parents, their wives, and their sweethearts. They kept diaries. They kept their memories and shared them with numerous interviewers in the recent West Virginia Veteran's Project. In 1946, West Virginia University asked all enrolled students who were World War II veterans to write a personal account of their experiences in the war. These accounts can be found in the West Virginia Regional and History Collection in Morgantown and they number over a thousand. All of these factors combine to potentially give historians a more thorough picture of how Appalachians react to violence than any other previous event. We really have no idea how a striking miner from Cabin Creek felt when he saw his first dead Baldwin-Felts Detective. And how many personal accounts of the Appalachian feuds have survived? But, by using letters, diaries, interviews, and written accounts of military service during World War II we can get a reasonably clear picture of the expectations, reactions, and perceptions mountaineers felt as they left their homes, were trained in the military, traveled overseas, and experienced combat. Additionally, the information on World War II is so abundant that there are near countless memoirs and accounts of other Americans, Japanese, German, British, and Russian soldiers' reactions to combat in the war. If indeed,

\footnotetext{
${ }^{31}$ James G. Jones, "West Virginia in World War II," (Ph.D Dissertation, West Virginia University, 1952) 390.
} 
the global stereotype of the inherently violent and culturally distinct mountaineer is true, then it stands to reason that his accounts and narratives of his military experiences and his reaction to the violence of war is going to be different than that of other combatants. If however, the experiences and accounts of West Virginians in combat is very similar to that of other combatants, then the evidence would imply that the violent stereotype needs serious reevaluation. Writers and scholars can label a group inherently violent and culturally backward with a few simple strokes of a pen. But the real test is how individuals react to violence itself. Were the mountaineers "exceptional" in their military service, as Eisenhower told the crowd at Mountaineer Field in 1947? Does the military experience of the mountaineer support the prevailing stereotypes of not merely Appalachian, but global mountain "otherness?" The empirical evidence surrounding combatants, West Virginian and otherwise, now gives us the opportunity to make a more detailed and thorough evaluation of the stereotypes associated with violent mountaineers than has ever been done before. This dissertation will embark on such an evaluation.

Organization of the Study

The rest of the study is divided into four chapters and a conclusion. Each chapter covers a transitional phase in the experiences and identity of West Virginia soldiers. The first chapter, "From Peace to War," examines the general reaction of 
West Virginians to the Japanese attack on Pearl Harbor and the various factors that motivated individuals in the Mountain State to enlist in the military. While nationalistic fervor and delusions of military glory influenced a small number of West Virginians, many more found themselves joining the war effort for better economic opportunities and, in a few cases, because of the social pressure applied to young men to perform their patriotic duty. Once in the military, young West Virginians found themselves traveling away from home and, throughout the course of basic training, were directly confronted with the stereotypes associated with Appalachia. Chapter Two, "From Locals to Appalachians," explores regional stereotypes associated with the mountaineers during training and how the men reacted to the stereotypes. The training experiences of the soldiers themselves contradict many of the supposed cultural traits attributed to Appalachia. However, a minority of mountaineers actually embraced popular images of mountaineers and through a process of "self-stereotyping" helped perpetuate distorted perceptions of Appalachia.

Once overseas, GIs from West Virginia were no longer associated with Appalachia in the eyes of the Europeans, Asians, Africans, and Pacific Islanders they encountered. To populations in other countries, all Americans shared similar characteristics. Chapter Three, "From Appalachians to Americans" looks at the mountaineers who served overseas but did not see combat. As West Virginia soldier narratives are compared with narratives from other American soldiers, unanimity of behavior among all American GIs trumped regional cultural 
variations. As the GIs drank copious amounts of alcohol, womanized, and paraded from town to town or island to island, they left many lasting impressions on the people they encountered. Furthermore, as the mountaineers reacted to these new places and cultures, their narratives reflect the racial and cultural values of Appalachia and America in the 1940s. In this sense, the soldier narratives are more valuable for what they tell us about Appalachia, than what they reveal about World War II.

The final chapter, "From Americans to Humans" analyses the shared environment of the battlefield between each of the belligerents and how the ordeal of combat is reflected in the soldier narratives. For the individual soldier, politics, ideals, and even cultural identity pale in comparison to traits shared by people of all nationalities and backgrounds. These shared traits are brought to the forefront by the battlefield experience. Or, in the words of British historian John Keegan, every soldier shared the similar experiences of "boredom, exultation, panic, anger, sorrow, bewilderment, even that sublime emotion we call courage."32

Amazingly, while there is an abundance of edited collections of soldier letters, diaries, and memoirs in World War II, there is very little comparative analysis of these narratives. Most of the books in print merely reflect the "historian as copy typists" and not as interpreters of the past. ${ }^{33}$ But upon examining various soldier narratives during the war, one is struck, not by a presence of cultural

\footnotetext{
${ }^{32}$ Keegan, The Face of Battle, (London: Viking Press, 1976), 47.

${ }^{33}$ Ibid., 33.
} 
diversity in the texts, but by the overarching similarities in the narratives. In his landmark book, The Face of Battle, John Keegan correctly asserts that "allowing the combatants to speak for themselves is not merely permissible, but when and where possible, an essential ingredient of battle narrative and battle analysis." ${ }^{, 34}$ I intend to use soldier narratives to do more than merely explain battles, but to give us a greater understanding of the war, the constructs of cultural identity, and how stereotypes, whether fabricated or not, are used to shape perceptions of culture.

${ }^{34}$ John Keegan, The Face of Battle, (London: Viking Press, 1976), 32. 


\section{Chapter One}

\section{From Peace to War}

If one is to begin a study of how the military experience of West Virginians in the Second World War erodes the validity of cultural stereotypes, there is no better starting point than the American reaction to the news of war. Regardless of ethnicity, region, race, culture, or gender, Americans everywhere found common ground when hearing of the Japanese attack on December 7, 1941. The way Appalachians initially responded and reacted mirrored other citizens around the country. Here are a few examples:

I'd been to mass at Saint Rose and was on the floor reading the funny papers when we got the news of Pearl Harbor. We had the radio on, probably listening to Glenn Miller or Benny Goodman. ... But these places were so far away from us. It just didn't seem possible that we were at war. ${ }^{1}$

I was seventeen when the war began. At the time we girls were playing Monopoly. Every night we kept the same game going and we always had the radio on with forties music and we had pretzels and Coke as dessert. All of a sudden the announcer stopped the music and told us what had happened. We had no idea where Pearl Harbor was, but it changed our lives forever. ${ }^{2}$

I get this strange feeling of living through a world drama. ... I was fourteen years old. I remember my mother saying, "Bob, you'll be in it." I was hoping she'd be right. At that age you

1 Account of Dennis Keegan, from Santa Rosa, California. Studs Terkel, ed., "The Good War": An Oral History of World War II (New York: The New Press, 1984), 25.

2 Dorothy Lucas interview by Angela Sirna, March 30, 2006, Inwood, West Virginia, CD Recording, West Virginia Veteran's Project, West Virginia University, Morgantown, WV (Hereafter cited as WVVP). 
look forward to the glamour and have no idea of the horrors. ${ }^{3}$

My next door neighbor and friend Martin Foley came out, and he was the same fella that told me about when Hitler invaded Poland. He came out and he says, "Pearl Harbor's been attacked by the Japanese! I just heard it on the radio!" And my first thought was where and what is Pearl Harbor? And so, I told my Dad when he came out and we went downtown and it hadn't come out in the news yet. I mean the newspaper. But, as we came back we turned on the radio, and that entire evening, and the next day and the next and hearing how many people were killed, estimates and everything. Looking back to it, it's hard to compare it to things that have happened since. I believe it was one of the most exciting nights of my life. I didn't think about the blood or the gore. All I thought of was the other stuff like, "were gonna get 'em, and it's glorious."

The above accounts come from Santa Rosa, California; Inwood, West Virginia; Chicago, Illinois; and Grafton, West Virginia. Although this is a small sampling of regions across the United States, one can quickly see consistency in the narratives. Americans on the continent had their daily lives interrupted by sudden news of a conflict that had finally, if only distantly, touched their homeland. No matter who they were or where they were, or whether the reaction was one of excitement, fear, awe, or simply silence, each of these four individuals knew that the war was going to change things dramatically, and each of them could previously only see the conflict as a far away event and place. In the last two examples, the naivety of war is also evident as the individuals recall their notions of glory juxtaposed against their later experiences of the horrors of war. Even for

3 Account of Robert Rasmus from Chicago, Illinois. Terkel, "The Good War," 38.

4 James H. Weekley interview by Franchesca Nestor and Matthew Grotkowski, November 25, 2004, Bridgeport, WV, transcription, WVVP. 
the mountain people of Appalachia, it felt as though not just the war, but the violence that comes along with war, was a world away.

As word of Pearl Harbor spread across the mountains everyone realized that this distant war was coming home, only no one knew exactly to what extent. In Fairmont, WV, Lysbeth Hunter recollects that a young boy who overheard news of the Japanese attack ran into her house in a panic because he thought Pearl Harbor was somewhere in West Virginia. ${ }^{5}$ The boy's reaction was a common one. A British journalist in Washington D. C. observed that many of the citizens he encountered in the nation's capital that day meandered about, "fuzzily wondering where Pearl Harbor was." " Albert Taylor from Charleston, the state capital of West Virginia, agreed. He arrived at his home to hear of the news from his father, who was a World War I veteran and was drunk. He said that Pearl Harbor, "could have been down at Patrick Street for all we were concerned." ${ }^{, 7}$ Across town, Jack Kieffer watched a movie with his friends when suddenly the movie stopped, the lights came on, and the theatre manager told the stunned crowd what had happened. Kieffer, who would later join the Marine Corps and fight in Saipan and

${ }^{5}$ Lysbeth Hunter and Joyce Ann Irons interview by Kashka L. Nelson, April 19, 2006, Colfax, WV, tape recording, WVVP.

6 Alistair Cooke, The American Home Front, 1941-1942 (New York: Atlantic Monthly Press, 2006), 6. This is a recently published book of a British journalist's account as he traveled across the United States during the first year of U.S. involvement. Among other places, Cooke visited West Virginia.

${ }^{7}$ Albert Beck Taylor interview by Matthew Mitchell, March 21, 2002, St. Albans, WV, transcriptions, World War II Interviews and Papers, West Virginia Division of Culture and History, Charleston, WV (Hereafter cited at WWII Interviews). 
Okinawa remembered that "Everyone was in awe." ${ }^{, 8}$ Less than fifty miles away in Huntington, Edwin Berry, who would also find his way to the Pacific, strolled out of the Keith-Albee Theatre only to find a paperboy standing on the sidewalk with the headline "Pearl Harbor Attacked." Even in a place as supposedly "culturally isolated" as West Virginia, the news traveled quickly.

The first few days following the attack on Pearl Harbor probably signaled the height of American nationalism and xenophobia in the twentieth century. By no means were Americans united about the war before Pearl Harbor, and a heated argument had been raging between isolationists and internationalists about whether or not to intervene in the conflict. December 7 radically changed everything. ${ }^{10}$ Just a few miles north of West Virginia, in Pittsburgh, Pennsylvania, U.S. Senator Gerald Nye, an outspoken isolationist, addressed an America First meeting when someone handed him a scribbled note informing him of the attack, obviously taking a bit of steam out of the peace rally. ${ }^{11}$ Former West Virginia Senator Rush D. Holt was working on his anti-war book, Who's Who Among Warmongers, when he found out about Pearl Harbor. Holt abruptly quit writing the book but offered no apologies for his stance on peace, even after he was accused of collaborating with George Slyvester Vierech, a known Nazi

8 Jack Kieffer interview by John Simms, April 24, 2002, St. Albans, WV, transcription, World War II Interviews, WVDCH.

9 Edwin C. Berry interview by Charles A. Nichols, May 7, 2002, Huntington, WV, transcript, WWII Interviews.

${ }^{10}$ For more on the isolationists and internationalists see Gary R. Hess, The United States at War, 1941-1945 (Illinois: Harlan Davidson, Inc., 2000), 2-8.

11 Cooke, The American Home Front, 6-7. 
Propagandist. ${ }^{12}$ Such a bold anti-war stance may seem odd coming from a senator who had represented the citizens of a region with a reputation for violent behavior. Regardless, Holt, Nye, and other isolationists were forced to confront the fact that the debate was over. In an editorial for the Charleston Gazette, columnist Raymond Clapper wrote, "Japan has made our decision for us. All of our doubts, all of our reluctance, all of our hesitations have been swept away for us.

Practically every leading isolationist already has been heard from. Their answer to the attack is that we must fight. .. . Japan has asked for it and now she will get it." 13

The United States was going to war and the vast majority of Americans were determined to support their nation as a wave of patriotism swept the country. Charles Lewis from St. Albans recalled it vividly, "The people were very patriotic. Pretty fired up. The Japanese had attacked us without any warning and the people were very mad, very upset." ${ }^{14}$ In Huntington, eighty-three men applied for military service the day after the attack, including a fifty-five year old dentist and World War I veteran. ${ }^{15}$ That same day over 200 men applied for enlistment in Charleston as Navy and Army recruiting stations inaugurated twenty-four hour office schedules. ${ }^{16}$ With the exception of the aging dentist, the most enthusiastic

12 Charleston Gazette, February 22, 1942.

13 Ibid., December 9, 1941.

14 Charles R. Lewis interview by Charles E. Smith, Jr., April 20, 2006, St. Albans, WV, transcript, WVVP.

15 Huntington Herald Dispatch, December 9, 1941.

16 Charleston Daily Mail, December 8, 1941; Charleston Gazette, December 9, 1941. 
responses seemed to come from young people. In other places around the state, young men, eager to be the first in their community to sign up for service, went straight to their local recruiting offices on the night of December 7 and waited all night until the offices opened in the morning. ${ }^{17}$ Students at Fairmont State College adopted resolutions of loyalty to the nation. ${ }^{18}$ West Virginia University's student newspaper, the Daily Athenaeum, printed a special edition the day of the attack. One of its several editorials concluded, "A lot of us will get a taste of what our fathers got in 1918 and a lot of us won't be back either. But there'll be another generation to take over where we leave off. May God help us in this, our battle for freedom." 19

To further facilitate patriotic fervor and popular support, the state's educational system, state government, and media immediately took action. Before the month had ended, secondary schools in West Virginia adopted an "Action for Victory" program initiated by State Superintendent W. W. Trent. The program, meant to groom youngsters for the war effort, intended to shape school curriculum in such a way as to emphasize American patriotic values and that every man, woman, and child played a role in the war effort. ${ }^{20}$ The West Virginia Maneuver Area was also established near Elkins and in parts of the Monongahela National Forest. Troops were trained for battle in mountainous regions, presumably for

17 The West Virginian, December 8, 1941.

${ }^{18}$ The West Virginian, December 9, 1941.

19 Daily Athenaeum, December 7, 1941.

20 Charleston Daily Mail, December 24, 1941, Parkersburg Tribune, December 26, 1941. 
operations in Italy. At Seneca Rocks, troops were taught assault climbing. Quartermaster units were trained to drive trucks on the mountain roads, and explosives were tested on Allegheny Mountain near Petersburg. ${ }^{21}$ The state's most prominent resort, the Greenbrier Hotel, served as a rather luxurious "prison" for Axis ambassadors still in the United States after the declaration of war, and later served as a hospital for injured soldiers, who recovered from serious wounds while eating on white-linen tablecloths and (if they were able) playing golf on the resort's private course. ${ }^{22}$ For its part, the media in West Virginia had an easy job whipping up fervor for the war in December 1941. Local newspapers played up the fact that seven West Virginians were at Pearl Harbor during the attack and three of them lost their lives. Additionally, the U.S.S. West Virginia was hit and sunk by Japanese planes at Pearl Harbor. Such facts, heavily reported by the media, only added fuel to the fire. Pete Winrich, who owned a newsstand in Huntington, bravely told reporters, "We're going to pour it on Japan.",23

Fueling the fire did not merely add to patriotic sentiment, but also to paranoia and xenophobia all across the country. Throughout the remainder of December 1941, cities on the west coast were filled with false reports of enemy planes and sabotage. Axis ships were supposedly spotted near the shores of

\footnotetext{
${ }^{21}$ James G. Jones, "West Virginia in World War II" (PhD diss., West Virginia University, 1952), 399-402.

${ }^{22}$ Louis E. Keefer, "Ashford General Hospital: The Greenbrier Goes to War," Goldenseal (Charleston: Fall 1993): 46-54.

23 Huntington-Herald Dispatch, December 8, 1941, Wheeling Intelligencer, December $12,1941$.
} 
Manhattan, and even a dog by the sea was reported as "barking" in Morse Code to a nearby Japanese ship. This nationwide panic accompanied with existing racial tension between American citizens, Japanese immigrants, (many of whom were also citizens), and Italian-Americans, would eventually lead to Japanese and Italian internment by the federal government. ${ }^{24}$ But such paranoia was not confined to one section of the country, locals in West Virginia followed suit. In Fairmont, Sheriff Russel Nichols doubled security at the city waterworks and instructed deputies to "check on any stranger in city streets after midnight." 25 Dick Wright, the sheriff of Hancock County, deputized sixty new men in Weirton in order to protect the town's steel plant. ${ }^{26}$ Within a week of the attack three Japanese-Americans were arrested in South Charleston after having been “spotted" possibly spying on one of Union Carbide's chemical plants. ${ }^{27}$ In a coal town in Logan County, two Japanese who worked for a company store were detained by state police for no other apparent reason than to prevent sabotage. ${ }^{28}$ While there are no available records of Italian-Americans in West Virginia arrested, social tension and discrimination still existed. Some schools in Clarksburg would not allow Italian students to use the front door of the schools, instead they had to use a side door. Additionally, Louise Caruso, the daughter of

${ }^{24}$ Ronald H. Spector, Eagle Against the Sun: The American War With Japan (New York: Vintage Books, 1985), 93-94; Lawrence DeStasi, ed., Una Storia Segreta: The Secret History of Italian American Evacuation and Internment During World War II (Berkeley, CA: Heydey Books, 2003), 1-11.

25 The West Virginian, December 8, 1941.

26 Wheeling-News Register, December 9, 1941.

27 Charleston Daily Mail, December 8, 1941.

28 The West Virginian, December 9, 1941. 
Italian immigrants in Morgantown, attended elementary school during the war. Her father emphatically told her, "You must never say that you are Italian. If anyone asks, you must reply by saying that you are an American." 29

While Italian-Americans certainly faced some discrimination, most of the racism and discrimination focused on Japanese-Americans. Here we already find examples of cultural stereotypes playing a role in state and social behavior. Well before President Roosevelt interned Japanese-Americans on the west coast, citizens all around the country, including West Virginia, were rounding up Japanese on their own initiative without the backing of the federal government. This evidence seems to support historian John W. Dower's argument that, in the wake of Pearl Harbor, the overwhelming perception of the Japanese was that they were "innately treacherous." ${ }^{30}$ Newspapers and propaganda in West Virginia and elsewhere stereotyped the Japanese as subhuman, scheming, yellow, and simian in nature. These characteristics were simply a part of their cultural makeup, according to government and media propaganda. As a result no Japanese person, American citizen or not, could be trusted. According to Dower, this logic dictated that their cultural traits would not allow them to be patriotic American citizens. Therefore, while nationalism played a significant role in the war, simply being the citizen of a nation was not enough, as many Japanese in the United States

${ }^{29}$ Louise Caruso interview by Leslie Saunders, April 4, 2006, Morgantown, WV, WVVP. Curuso also relayed the story about Italian-American kids in Clarksburg schools.

30 John W. Dower, War Without Mercy, Race and Power in the Pacific War (New York: Pantheon Books, 1986), 36. 
discovered. Ethnicity and the belief in stereotypes trumped nationality. ${ }^{31}$

Newspapers all across West Virginia did not hesitate to lump these stereotypes on the Japanese during the first month after the attack. Editorials in the Charleston Gazette and the Huntington Herald-Dispatch readily referred to the "Japs" who were backstabbing yellow bullies, among other things. ${ }^{32}$ West Virginia state officials and the general population seemed to have been very much in step with the national trend in this case. More importantly, however, we see a few early examples of how cultural stereotypes became a prominent force in shaping America's and West Virginians' perception of the war. West Virginians had long been accustomed to stereotypes of their own culture in the media. With the onset of war, they would not only continue to face stereotypes of their own mountain culture in the years to come, they would also be forced to confront popular stereotypes of numerous other cultures and ethnicities. The Japanese were merely the most prominent at the beginning of the war.

Oversimplification is often an unfortunate bedfellow accompanying interpretations of the Second World War. Michael C. C. Adams wrote that in the decades since the forties World War II, "has been converted over time from a complex, problematic event, full of nuance and debatable meaning, to a simple

\footnotetext{
31 Ibid., 81-89.

32 Huntington-Herald Dispatch, December 9, 1941, Charleston Gazette, December 8, 1941. Examples of racial stereotyping of the Japanese in West Virginia newspapers is very prevalent and is very much in step with media coverage around the country. Among others see, The Wheeling Intelligencer, Parkersburg Sentinel, Charleston Daily Mail, and the Fairmont Times.
} 
shining legend of the Good War." 33 It would be easy for the historian to examine the evidence mentioned above and jump to a few hasty conclusions. Such an interpretation might go like this: After Pearl Harbor was attacked, West Virginians quickly became caught up in a whirlwind of nationalism and racial animosity towards the Japanese and thus, with dreams of national glory, duty, and revenge, enthusiastically went off to war. Or the same argument could be paraphrased by taking a sampling of two separate accounts of West Virginia soldiers. Golden Crane, as he remembered the war from his home in St. Albans told an interviewer. "A neighbor ran to our door and told us that she heard about Pearl Harbor on the radio. My mom cried and cried. I immediately wanted to join." ${ }^{34}$ Perhaps Elmer Hendershot's written account is even more emblematic of a euphorically xenophobic and nationalistic America. "I could hardly believe that the little monkeys of Nippon would be so audacious as to attack the greatest country in the world. But from that date, December 7, 1941, my only desire was to get into the fight. Like every other young American I had my dreams of valor and distinction. There is no law against dreaming." 35

Could it really be so simple? Did everyone merely answer the call from Uncle Sam and rally behind the Stars and Stripes to do their duty and serve their country? If one merely looks at the immediate reaction to Pearl Harbor, one can

33 Michael C. C. Adams, The Best War Ever: America and World War II (Baltimore: Johns Hopkins University Press, 1994), 2.

34 Golden Crane interview by Josh Arthur, March 2, 2002, St. Albans, WV, World War II Interviews.

${ }^{35}$ Account of Elmer Hendershot, World War II Records, WVRHC. 
just as easily fall prey to the rush of emotions that engulfed the country like a great flood in December 1941. Certainly there is some truth to the interpretation above, but history is rarely ever so simple. If we are to gain a greater knowledge of cultural stereotypes and the fallacies behind them, we must examine all the factors that contributed to a West Virginian's decision to enlist. As will be discovered, it was not all about patriotism. Economic factors and peer pressure, alongside a variety of other elements also played significant roles. Furthermore, what better place to examine the difference between cultural reality and cultural stereotypes than by studying the recollections, letters, and accounts, of young West Virginians and other Americans, as they all remember their reactions to the attack and their motives for joining the military. The rest of this chapter will examine the stimulating factors for military enlistment by West Virginians in World War II. But, in order to put the most prevalent reasons behind what motivated West Virginians to join the military we must understand the cultural climate, both real and imagined, that surrounded them.

\section{West Virginia on the Eve of War}

In 1941 West Virginia was a poor place with a poor reputation. With a population consisting largely of rural farmers and a downtrodden working class, the first four decades of the twentieth century had brought industrial conflict and extreme poverty. From 1912 to 1933 industrial violence in West Virginia, 
particularly in the coalfields, caught the attention of the nation, but the various local and worker revolts failed to successfully unionize the state or take the balance of power away from the captains of industry. After making some brief headway in the state between 1912 and 1921, the United Mine Workers of America collapsed in West Virginia after the failed Armed March on Logan and the subsequent treason trials. Through a series of prosecutions against union leaders and by securing injunctions against organized labor, business leaders had virtually eliminated unions throughout the state by the onset of the Great Depression. The plight of the working class was further exacerbated by a bust period in the coal industry and the fact that West Virginia had been deforested to the extent that the timber industry had also severely declined. The extraction industries had failed to provide stability to the local economy and by the time Democrats swept into power on both the local and national level in the 1932 election, economic conditions in West Virginia were among the worst in the nation. ${ }^{36}$

The Great Depression took hardship to a new level as locals sought to make ends meet and fight off hunger. Catherine Owens recalled that her family raised chickens to feed themselves, but without any income for the family, her mother made feed sack dresses for Catherine and her sisters to wear to school. ${ }^{37}$ Dorothy Johnson of Parsons had similar memories. "My mother had to sell the

36 C. Belmont Keeney, "A Republican for Labor: T.C. Townsend and the West Virginia Labor Movement, 1921-1932," West Virginia History, Volume 60, 2004-2006: 1-22.

37 Catherine Owens and Jean Spurlock interview, WVVP. 
only cow that we owned to have enough money to buy food. But my father was a World War I veteran and we three children did receive eight dollars a month from the government. That's how we survived during the Depression. But my mother would also work. She would go out and work in fields, even when she was pregnant. Hoe corn for a dollar a day." 38 Such dire circumstances increased many West Virginians' dependence on government aid. "We had a very hard time," Evelyn Whisler, of Morgantown remembered, "my father was a coal miner and the government passed out hundred pound bags of potatoes for us to plant and, of course, we ate half of them before we planted them." 39

As Whisler's comments reveal, Franklin Roosevelt's New Deal programs such as the Federal Emergency Relief Administration (FERA), the Civilian Conservation Corps (CCC), and the Public Works Administration (PWA), provided some relief and a few jobs, but many of the federal programs were not given significant backing from local politicians. The economic crisis had driven Republicans out of power and enabled Democrats to gain control of state politics. However, as historian Jerry Bruce Thomas has shown, the two Democratic governors in the thirties, Herman Guy Kump and Homer Adams Holt, were at best, reluctant New Dealers. These governors were more in line with southern conservatives who disapproved of Roosevelt's expansion of the federal

38 Dorothy Johnston interview by Megan Osgood, Parsons, WV, April 15 2006, WVVP.

39 Evelyn Whisler interview by Lindsey Felton, Morgantown, WV, April 28, 2006, WVVP. 
government. ${ }^{40}$ With the passage of the Wagner Act in 1935, West Virginia workers were able to successfully unionize, and by 1940, labor had grown powerful enough to elect Matthew Mansfield Neely, a pro-New Dealer, to the governor's office. However, before Neely could take full advantage of Roosevelt's federal programs, the war had begun and the New Deal came to a swift end. ${ }^{41}$

It is not surprising then, when FERA agents came to inspect the economic conditions in West Virginia, they were flabbergasted and dismayed at the conditions they found. They discovered that more than two thirds of the state's coal mines were out of operation. In Logan County over 1,300 miners lived off government relief while over 1,500 had left the county searching for work elsewhere. At one point in the Depression, places like Scott's Run and Scottsdale reported an unemployment rate of nearly ninety seven percent. Many residents lived in overcrowded, run down company houses with horrible sanitation and water supplies polluted by industrial waste. Such conditions led Lowell Thomas, of FERA, to describe Scott's Run as the "foulest cesspool of human misery this side of hell. ${ }^{42}$ Henry Francis, another New Deal reporter, believed conditions in West Virginia to be worse than anywhere else in the country. He simply wrote,

40 Jerry Bruce Thomas, An Appalachian NewDeal: West Virginia in the Great Depression (Lexington: University of Kentucky Press, 1998), 211-233.

${ }^{41}$ Ibid., 232-240.

42 John F. Bauman and Thomas H. Coode, In the Eye of the Great Depression: New Deal Reporters and the Agony of the American People, (Dekalb: Northern Illinois University Press, 1988), 97-101. 
"They are marked for death here, marked by the hundreds." ${ }^{43}$ Lorena Hickok was shocked to find that, because of so many deaths in mining accidents, starvation, and the spread of pneumonia and typhoid, Logan County made coffin making one of their relief projects. ${ }^{44}$

Even though the FERA agents and other outside observers expressed pity and disgust with what they saw, they tended to blame the economic plight of West Virginians and Appalachians on the culture of the mountaineers themselves. Henry Francis referred to the poor in West Virginia as "both socially and physically defective" and wrote that the situation was hopeless because, "You can't interest [the mountaineers] in bettering themselves." ${ }^{45}$ Martha Gellhorn attributed the spread of disease and hunger in the region to inbreeding and ignorance. She wrote, “Why they aren't all dead of typhoid, I don't know. It probably would be a blessing if they were."

The hardships facing mountaineers raised concerns among the New Deal reporters and others that the supposedly inherent violent side of the mountain people would rear its ugly head. Images in popular culture helped reinforce these ideas. The biggest box office Hollywood hit in 1941 was the film Sergeant York. The film, loosely based on the life and war exploits of the Tennessee mountaineer who became the most famous American hero of World War I, grossed over sixteen

\footnotetext{
43 Ibid., 102.

44 Ibid., 102-103.

45 Ibid., 105.

46 Ibid., 103.
} 
million dollars in the domestic box office. Adjusted for 2009 inflation, its box office gross equals $\$ 340,596,300$, making it the ninety-fifth most profitable film in United States history. ${ }^{47}$ Sergeant York can rightly be called a piece of propaganda intended to prepare the American public for war. Gary Cooper's portrayal of Alvin York won him the Academy Award for best actor. ${ }^{48}$ According to the film, York was a "fightin' an' hell-raisin' mountain farmer" who "found religion" and turned to pacifism after he was struck by lightning. Once the Great War began York was convinced to fight and used his mountain skills to vanquish the enemy with more efficiency than any other soldier. During the fighting, he merely pretended the Germans were wild game. ${ }^{49}$

Adding to this depiction of the violent mountaineer was the popular book, Bloody Ground. Published nationally in 1941, the book chronicled John F. Day's travels in West Virginia and Kentucky in the year before Pearl Harbor. Day, while reinforcing popular stereotypes of the region (inbreeding, isolation, independent spirit, and uneducated) seemed most fascinated with what he felt was a culture of violence and a wanton "disregard for human life. ${ }^{, 50}$ In his discussion of vendettas and feuds, Day wrote, "If there is a synonym for vindictiveness, it is mountaineer." ${ }^{51}$ The mountaineer's desire for vengeance, if crossed, would not diminish over time. "Never will [the mountaineer] forgive or forget a real or

\footnotetext{
${ }^{47} \mathrm{http} / / / \mathrm{www} \cdot$ boxofficemojo.com/alltime/adjusted/htm.

${ }^{48} \mathrm{http}: / / \mathrm{www} . \mathrm{imdb} . \mathrm{com} / \mathrm{title} / \mathrm{tt0034167.}$

${ }^{49}$ New York Times, July 3, 1941.

50 John F. Day, Bloody Ground (New York: Doubleday, 1941), 116-117.

51 Ibid., 117.
} 
imagined insult and his desire for revenge never lessens until the score is

settled." ${ }^{52}$ Day wrote that acceptance of violence is embedded in the mountaineer from an early age. Indeed, he claimed, the biggest moment in a young mountaineer's life is the day he gets his first gun. ${ }^{53}$ Day and the FERA agents were not alone in their condescending assessment of the region. British historian Allan Toynbee reiterated these conclusions in his 1947 international bestseller $A$ Study of History, calling Appalachian mountaineers "no better than barbarians.",54

This notion of the violent hillbilly, historian Anthony Harkins noted, "penetrated deeply into American culture, especially during World War II." Aside from books and FERA reporters, cartoons printed in popular magazines reinforced the stereotypes. Esquire, not to mention many of the nation's major newspapers, printed comic strips aimed specifically at Appalachians. Two of the more popular ones were The Mountain Boys and Barney Google. A perfect example of how these comics reinforced violent stereotypes can be found in a 1944 printing of Barney Google. As one of the mountaineers, Snuffy, was away fighting the war, his wife, who misses her husband, has Barney dress up in her husband's old clothes and chase her around the house with a stick while she cries, “Sich purty mem'ries!!!",56

\footnotetext{
52 Ibid., 27.

53 Ibid., 119.

54 Arnold J. Toynbee, A Study of History (New York: Oxford University Press, 1947), 119. Toynbee's book sold over 200,000 copies in the United States.

${ }^{55}$ Anthony Harkins, Hillbilly, 136.

${ }^{56}$ Ibid., 105-116.
} 
Perhaps the most striking aspect of these accounts is that by all appearances, these writers and observers, despite being educated professionals, sincerely believed that the traits of cultural backwardness, violence, and poverty, were real and embedded into the inhabitants of Appalachia. Certainly in 1941 West Virginia was a state with severe economic troubles, but it was not because, as Henry Frances believed, that the citizens of West Virginia had no desire to better their lot in life. Nonetheless, this still does not explain away the perception of an inherently violent Appalachia. If mountaineers never forget an insult, real or imagined, and if they are prone to violence, wouldn't it seem natural that many West Virginians would have signed up for military service simply because they loved to fight? In order to answer these questions, we must now examine what specifically motivated men and women in West Virginia to enlist for service in the bloodiest war in human history.

\section{Why They Enlisted}

Well before there was D-Day, there was R-Day. As the Axis Powers expanded their conquests in Europe, Asia, and Africa, President Roosevelt and his military advisors were convinced that eventually the United States would enter the war on the side of the Allies. The only real question was when. So that the nation would be a little more prepared for the conflict than in 1917, when the U.S. entered World War I, the administration decided to prepare for a military draft. 
Thus, on October 16, 1940 in accordance with the recently signed Selective Training and Service Act, young men from all around the country were required to register for the draft. Around sixteen million men between the ages of twenty one and thirty five signed up on R-Day. ${ }^{57}$ In West Virginia, 240,379 men registered and by the attack on Pearl Harbor, 34,550 West Virginians were in active military service. $^{58}$

Each state was required to run a division of the Selective Service. Originally, the Selective Service drafted exclusively for the Army while the Navy, Marines, and Coast Guard were left to fill their manpower needs by recruiting. Congress limited the terms of draft service to one year and authorized the Army to take no more than 900,000 men unless there was a declaration of war. After Pearl Harbor, the 900,000 man limit was dropped and enlisted men were required to stay in the Army for the duration of the war plus six months. Soon the local draft boards were working overtime. ${ }^{59}$ The Selective Service in each state oversaw local draft boards. It was up to these draft boards to decide who went to war and who stayed at home. Draft boards usually consisted of five men in their forties or fifties, who were locally prominent individuals from a variety of professions. Many of the boards had one representative from industry, one from labor, one farmer, one doctor, and one lawyer. As often as possible, the Selective Service

${ }^{57}$ Lee Kennett, G.I.: The American Soldier in World War II (Norman: University of Oklahoma Press, 1997), 4-7.

${ }^{58}$ Jones, "West Virginia in World War II," 380-382.

59 Kennett, G.I., 6-7. 
also chose war veterans to be on the boards, the idea being that the board members would not be asking young men to do something they had not already done themselves. For example, Sergeant Alvin York, the famous Appalachian hero of World War I, served as chairman of his local board in Franklin, Tennessee. ${ }^{60}$ Governor Neely headed up the Selective Service in West Virginia. Ninety local draft boards were created in the state and there were four appeal boards. Board members served without pay and around two hundred physicians and dentists were appointed to examine draftees to make sure they were fit for service. ${ }^{61}$

The process by which men were chosen or exempt from the draft was, at least on the surface, very democratic and in the hands of local citizens. Strangers did not send young men away to war. Instead neighbors and sometimes family members decided who stayed behind and who went. A number of factors determined whether or not a young man was drafted. Boards tended to send bachelors before married men and married men with no children before married fathers. Workers in defense plants and other industries such as coal and steel were often given deferments. However, sometimes the draft was used for strikebreaking. ${ }^{62}$ African Americans were also often exempt from the draft because the Army would not use them in combat and would only allow for a maximum of ten percent of African Americans to be a part of the draft. African Americans were placed on such a low priority because of the stereotype that they

\footnotetext{
60 Ibid., 9-10.

61 Jones, "West Virginia in World War II," 377-379.

62 Kennett, G.I., 11-15.
} 
were inherently lazy and unintelligent and thus, would be ineffective in combat another example of stereotypes affecting state policy. ${ }^{63}$ Those moved to the front of the draft line, aside from bachelors, were men in professions deemed most useless for the war effort. Thus, the two professions with the highest proportion of draftees were actors and professional athletes. Over $50 \%$ of all working actors in the United States were drafted in World War II. ${ }^{64}$

West Virginia, with a population of $1.42 \%$ of the national population, contributed $1.46 \%$ of the total number who enlisted in the United States Army, ranking them fourteenth among the forty-eight states in terms of proportion of population who served. ${ }^{65}$ These figures put West Virginia in the top one-third of states as a percentage of the population who joined the Army. While many of these young men were drafted, many more chose to enlist. As will be demonstrated, the reasons that motivated West Virginians to enlist are so varied it is difficult to ascertain a single overall motive. The accounts of most veterans indicate that the most prevalent motives outside the draft were money, the career opportunities that the military provided, and peer pressure.

The military provided an escape from the Depression, not just in West Virginia, but around the country. Here we find that not only were the FERA reports incorrect in their assumptions that mountaineers had no interest in

\footnotetext{
63 Neil A Wynau, The Afro-American and the Second World War (New York: Holmes and Meier, 1976), 31-32.

64 Kennett, G.I., 15.

65 The official U.S. Army casualties and enlistment percentages for each state can be found at http://www.archives.gov/research/arc/ww2/army-casualties/index.html.
} 
bettering themselves, but also their reasons and motives for enlistment were very similar to those of other young men across the nation. Everyone suffered in the Depression and everyone wanted a way out. Such was the case with Alvin Bridges of Bay City, Michigan, who put it bluntly. "I joined the Army on February 20, 1942, to get somethin' to eat." ${ }^{, 66}$ Raymond Young was just as blunt. When asked by an interviewer why he enlisted he said, "I couldn't find work." ${ }^{\text {67 }}$ Echoing Bridges' and Young's sentiment was Merald C. Fore of Charleston. His family had struggled mightily during the Depression. Merald's father had died during the influenza epidemic of the First World War and his mother worked in a laundry to feed him and his brothers and sisters. When he was fourteen, Merald quit school and began working on a milk truck. As he went about his daily routine delivering milk on the west side of Charleston, he heard about Pearl Harbor. He began to think of the bigger paycheck he could get from Uncle Sam and how his family could use the extra money. Merald joined the Navy ten days later. ${ }^{68}$ George Kovach, the son of an immigrant coal miner in Logan County, decided not to follow in his father's footsteps and left the coal mines for service in the Navy. He said he did so for a simple reason - "better pay." ${ }^{, 69}$ Nick Oliver graduated the valedictorian of his class in Morgantown but could not find work, so he joined the

\footnotetext{
${ }^{66}$ Terkel, 387.

${ }^{67}$ Raymond Young interview by Brian Humphreys, March 29, 2002, St. Albans, WV, Veteran's Interviews, WVDCH.

${ }^{68}$ Merald C. Fore interview by Cynthia R. Allred, St. Albans, WV March 18, 2002, WVVP.

69 George Kovach interview by Matthew Chambers, Morgantown, WV, December 3, 2004, WVVP.
} 
Marines. ${ }^{70}$ Perhaps Robert Lekachman summed it up best for many Americans best when he said, "The Army provided me with my first steady job."71

Many young mountaineers felt that the military could better their lot in life and provide them with career and educational opportunities. Leon Valley, who worked as an apprentice machinist in Moundsville, believed that the Navy not only provided an escape from tough times in the Depression, but the training he would receive in the Navy would equip him for better employment after the war ended, so he signed up. ${ }^{72}$ Clyde Judy grew up in downtown Fairmont. When the war began, he was "clipping stogies" in his uncle's cigar factory and he saw, in the military, a means of escaping factory life. The Army had set up a pilot training program through Fairmont State College. Clyde, and some of his friends such as Chuck Yeager, joined up because the "government would pay us forty dollars if we would sign up to get a pilot's license.,"73 Throughout his training he flew practice flights from one grassy airstrip to another all around central and northern West Virginia, while getting his college tuition paid. Aside from the rigors of academic life, he soon found that training in a mostly rural state did have its obstacles. The pilots often had problems with cattle grazing on the airstrips, and the pilots would have to make a few low passes to scare off the cattle so they

\footnotetext{
${ }^{70}$ Nick Oliver interview by Ashley Strickler and William Shalhoub, November 16, 2004, Morgantown, WV, WVVP.

71 Terkel, The Good War, 66.

${ }^{72}$ Leon Walley interview by Matthew Schnupp, Moundsville, WV, November 29, 2004, WVVP.

${ }^{73}$ Clyde Judy interview.
} 
could land. ${ }^{74}$

Certainly many young men around the country would have enlisted for economic opportunity due to the Depression. Because West Virginia faced more economic hardship than most of the rest of the country, more mountaineers may have enlisted for a paycheck than in other regions, although current data does not give us any definitive answers. From an international view of mountaineers in the military, a desire for employment seems to be a common thread. Grant Simpson, in his study of Scottish Highlanders and military service speculates that monetary opportunities lured many Scotts into British forces. ${ }^{75}$ Heather Streets reiterates this point when looking at Himalayan soldiers in the British Empire. ${ }^{76}$ While it is a fact that military recruiters have specifically targeted Appalachians throughout the twentieth century it is impossible to know exactly how much this is due to poverty, the idea that mountaineers are better fighters, or a combination of factors. ${ }^{77}$ Nevertheless, money appears to be at least one important motive for military enlistment of mountaineers in more than just Appalachia.

That many mountaineers enlisted because of their poverty contradicts popular images of the culture. The above evidence tells us that Appalachians were quick to pounce upon the economic opportunities provided by military service in

74 Clyde Samuel Judy interview by Randy A. Smith and Chris Gasper, Fairmont, WV, December 2, 2004, WVVP.

${ }^{75}$ Grant G. Simpson, ed., The Scottish Soldier Abroad, 1247-1967 (Edinburgh: Billings and Sons, 1992), vii-x.

${ }^{76}$ Heather Streets, Martial Races: The Military, Race, and Masculinity in British Imperial Culture, 1857-1914 (Manchester: Manchester University Press, 2004), 150-160. ${ }^{77}$ Williams, Appalachia, 379-384. 
the war. Mountaineers wanted to better their lives and were willing to take steps to do so, provided the chance. Unfortunately, observers of the time did not believe that Appalachians were self-motivated enough to better themselves. A generation later, social scientists of the 1960s reiterated and expanded upon the conclusions put forth by the FERA reporters and claimed that Appalachians had retreated into a "culture of poverty." According to this sociological model, geographically isolated mountaineers clung to a pre-modern culture and resisted the natural evolution into mainstream American modernity. This reluctance to change due to cultural isolation impeded economic development and created a cycle of poverty fed by the culture. ${ }^{78}$ What so many have failed to understand is that Appalachia in the 1940s was not a culture of poverty, it was a culture in poverty. The fact that so many West Virginians were willing to enlist in order to get out of poverty shows that they wanted to better themselves. Furthermore, sociologists felt that the hundreds of thousands of outmigrants from Appalachia in the fifties and sixties indicated that parts of the region's population were being integrated into the sociocultural mainstream of American life. ${ }^{79}$ These sociologists failed to realize that an entire generation earlier Appalachians had left the mountains by the hundreds of thousands by joining the military and working in war production plants. Enlisting in the military and moving to a large city for work meant travelling far from home, demonstrating that even if some Appalachians were

\footnotetext{
${ }^{78}$ Ronald L. Lewis and Dwight B. Billings, "Appalachian Culture and Economic Development," Journal of Appalachian Studies (Spring 1997): 4-5.

${ }^{79}$ Ibid., 4.
} 
isolated in 1941, they were not willing to remain so. By contrast, they were eager to change their circumstances in life. Such a reality does not endear itself to the observations of mainstream America during the war or to the Culture of Poverty explanation given a generation later.

If the draft and simple economics failed to motivate young men to join, peer pressure often provided another essential "push over the edge." To go meant patriotism and bravery. To stay behind meant cowardice. Keith Cooke, from Buffalo City, recalled that nearly every young man in the area, save those who "stayed out because of some type of ailment," went into the service. But he said that he and most of his friends were, "not that enthusiastic about going into the military." ${ }^{80}$ This reluctance to join up was shared by young men outside West Virginia as well. Ray Wax of New York City said, "Though I thought the war was important I really didn't want to go." ${ }^{, 1}$ Why then, did they go? Alan Goodykoontz's reasoning helps to answer the question. He felt as though he would be looked down on by the community if he did not enlist. "It was the in thing to do," he said. ${ }^{82}$ All over the country, boys often preferred, or at least felt more comfortable, signing up with groups of friends. Bill Allen and about twenty of his

\footnotetext{
${ }^{80}$ Keith Cooke interview by Matthew Shamblin, Charleston, WV, March 9, 2002, WVVP. Buffalo City, located in Logan County, would later be renamed Mann. Keith's father was the first mayor of Buffalo City.

${ }^{81}$ Terkel, 301.

${ }^{82}$ Alan Goodykoontz interview by Sarah Goodykoontz, Bluefield, West Virginia, April 3, 2004, WVVP.
} 
friends from Wheeling joined up immediately after their high school graduation. ${ }^{83}$ Jack Kieffer and all of his classmates from Charleston did the exact same thing. ${ }^{84}$ Lowel Steward of Los Angeles shared a similar experience with all of his high school buddies. "We had decided among ourselves that we would all go into the Air Force." And so they all went together. ${ }^{85}$ A letter from Don Louden to his mother is even more revealing. As he endured basic training, Don wrote that he was jealous of some of the boys back home, "with all the girls and my being stuck in a place like Texas. But I know that I wouldn't trade places with any of them. Not because I like the Army but because I hated to walk down the street when all the rest of the guys my age were in uniform.. ${ }^{, 66}$ Clyde Reed, of Mingo County simply wrote, "I hated the thought of going [into the Army] but I could not back out." ${ }^{87}$ Perhaps then it was not patriotism but the fear of being called anti-patriotic and the fear of being left out caused many young men to hop on the Arsenal of Democracy's bandwagon.

The motives listed above, while certainly the most prominent motivational factors, cannot encompass every reason for every person. It should naturally come as no shock that a society that champions individualism as much as the United States would have citizens choosing to sign up for every imaginable reason.

\footnotetext{
${ }^{83}$ Written Account of Bill Allen, World War II Records (Hereafter cited as WW2R), WVRHC.

${ }^{84}$ Jack Kieffer interview.

${ }^{85}$ Terkel, 343-344.

${ }^{86}$ Don Louden to Phyllis Louden, November 26, 1943, Greg Louden Personal Family Collection, Cheat Lake, WV.

${ }^{87}$ Account of Clyde Reed, World War II Records, WVRHC.
} 
Garnett Fuller, from Bluefield, was another coal miner who could have been deferred but decided to go fight. His reason? "I felt I had a better chance of surviving war with the Japs than staying in a West Virginia coal mine." ${ }^{88}$ Junior Gordon Arnold joined the Navy at age sixteen after hearing that his cousin had been killed in action. He decided upon the Navy because, "I figured I could swim further than I could march." ${ }^{" 89}$ Wallace Shatzer also chose the Navy over the Army. His reasoning lay behind the horror stories his father had told him about the trenches in World War I. ${ }^{90}$ Reasons were just as diverse in other states. Bill Mauldin of Santa Fe, New Mexico, signed up for the National Guard to avoid being drafted and sent to the infantry. Herman Kogan of Chicago volunteered for the Marine Corps for no other reason than to spite his parents. ${ }^{91}$

All of these examples serve to tell us that there is no single overarching stimulus prodding young men into the military during World War II - Appalachian or otherwise. Some went out of a sense of patriotic duty, some for money, some because of peer pressure, some because of their own personal reasons, and some were merely drafted. One can only conclude that in the wake of Pearl Harbor there was a unanimity of diversity in the attitudes of young men across the United States

${ }^{88}$ Garnett Fuller interview by H. Renee Viers, Bluefield, WV, June 26, 1992, transcription, Eastern Regional Coal Archives, Bluefield, WV. Fuller's logic was wellfounded. During the First World War, West Virginia coal miners suffered a higher casualty rate than the American Expeditionary Force in Europe. See Corbin, Life, Work, and Rebellion, 16-17.

89 Junior Gordon Arnold interview by Jackie Ayres, Morgantown, WV, November 9 , 2004, transcription, WVVP.

90 Wallace M. Shatzer interciew by Kim Bailey and Thomas Luria, Morgantown, WV, November 7, 2004, WVVP.

${ }^{91}$ Terkel, 360-364. 
regarding their military enlistment in the Second World War. In accordance with the reasoning of Michael C. C. Adams, World War II was much more than a black and white, good guys verses bad guys affair. The "greatest generation" did not all unanimously flock to the stars and stripes to do their patriotic duty, being of one mind and spirit - as nationalistic myth would have us believe. As with the rest of the war, the reactions and motives of all Americans were much more complex and varied.

However, there are a number of reasonable conclusions that can be drawn from how West Virginians reacted to the war and military enlistment. First, the responses of West Virginians to Pearl Harbor show that they were very much in step with the rest of the country, contradicting the cultural stereotypes promoted by writers and the FEMA reporters. West Virginians did not act more eager to fight than anyone else, and behaved, like the rest of the country, with shock and with a wave of nationalism and xenophobia. It was seen in how the general public in West Virginia portrayed and behaved towards the Japanese, as well as the public displays of patriotism by university students, newspapers, and ordinary citizens. Second, in a state overwhelmed with economic woes, scores of West Virginians saw in the military a means of bettering their monetary status and jumped at the chance to earn more money for themselves and their families. The eagerness of numerous young men to enlist for a better paycheck (and, in some cases their first paychecks) shows that their culture did not necessarily innately lead them towards poverty. Before they fought the Germans or the Japanese, West 
Virginians fought poverty whenever they could. Finally, the fact that large numbers of boys felt pressured by society to join the military also shows a reluctance for fighting on an individual level that is not indicative of a supposedly violent culture. In short, the above evidence suggests that West Virginians in 1941 behaved in very similar ways to most other Americans. But as they left their homes and their families for basic training they would still yet have to confront a larger society that firmly believed in their inherent cultural otherness. How the mountaineers confronted these stereotypes when they arrived for boot camp, how it affected their own identity, and how it changed (or sometimes perpetuated) others' perception of them is the subject of the next chapter. 


\section{Chapter Two}

From Local to Appalachian

As we have seen, West Virginians who chose to go to war voluntarily did so for a wide variety of reasons. Regardless of personal motives, once the choice was made, or draft notice received, each person would then embark on a journey that would draw them to military bases far from their hometowns, mix them with fellow countrymen of varying ethnic origins and regional affiliations, transform them into men of war, and then send them across the world to fight for their country. Just as December 7, 1941 was a watershed moment for the United States as a nation-state, the date of enlistment was a watershed moment in the life of the individual. The men and women who left for war and lived to return would be forever changed. This chapter will examine the first phase of that change military training.

The military training given to West Virginians in World War II altered the identity of the individual in two significant ways. First and most predictably, it changed the individual from a civilian to a soldier. The process was not always easy, nor the transition smooth. The military attempted to transform men who had grown up in a free democratic society into obedient servants, deconstructing the individual and constructing a collective fighting spirit within their men. Even with the supposedly violent mountaineers of West Virginia, turning peaceful civilians into killing machines was no simple task. Soldiers, whether West Virginian or not, 
often heavily resisted these changes imposed on them and yet, left the country willing to go to war.

Second, and less predictably, it altered their cultural identity from a local one to a regional one. As we shall discover, most West Virginians, despite living in a post industrial society, identified mostly with their hometown or native county. An individual from Charleston, for example, often believed himself to be culturally distinguishable from someone living in Logan County. However, once they entered boot camp, officers and other soldiers alike identified them with a particular region of the nation. A person from Mobile, Alabama became a southerner, a boy from Buffalo, New York, became a Yankee, and a kid from Fairmont, West Virginia became an Appalachian hillbilly. As the perception of each person became associated with a region within the United States, the stereotypes of each region were imposed upon the individual as well. Some West Virginians, as we shall see, resisted this oversimplification of their persona, while others readily embraced these stereotypes and, in the process, helped perpetuate them. The boot camp experience in World War II, as opposed to fusing all recruits and draftees into a single American identity, actually reinforced regional identity. 


\section{Civilians to Soldiers}

Before Pearl Harbor, the combined number of enlisted men in all branches of the U.S. military numbered a little less than 500,000. ${ }^{1}$ By the end of the war, over sixteen million would serve. ${ }^{2}$ Thus, in the transition from peace to war, the logistical difficulties alone of assembling, training, supplying, and deploying such a large and effective military force from a country as vast and diverse as the United States was nothing short of monumental. Revisiting his initial reaction of America's entry into the war, Winston Churchill jubilantly wrote, "Hitler's fate was sealed. Mussolini's fate was sealed. As for the Japanese, they would be ground to powder." It was much easier said than done. The manpower and industrial capacity of the United States could, and indeed did, play a crucial role in the Allied victory of the war, but in December 1941, America had yet to turn its military and industrial potential into reality. Civilian factories needed to be transformed to fit within the military industrial complex. Toy factories would now make bullets. Consumer goods would be rationed and millions would sign up to fight. In order for victory to be achieved, the U.S. government would have to accomplish all of these transformations, coordinating a societal effort on a gargantuan scale without totalitarian rule.

\footnotetext{
${ }^{1}$ Thomas Ayres, A Military Miscellany (New York: Bantam Books, 2006), 49.

${ }^{2}$ Michael C.C. Adams, The Best War Ever: America and World War II (Baltimore: The John Hopkins University Press, 1994), 70.

${ }^{3}$ Winston S. Churchill, The Second World War, Volume 3: The Grand Alliance (New York: Bantam Books, 1962), 511.
} 
A great sense of urgency compounded these logistical difficulties. Four days after the attack on Pearl Harbor, Hitler declared war on the United States. Even though Hitler's Blitzkrieg war machine had stalled at the gates of Moscow and Leningrad, the Soviet Union's survival was still very much in doubt. The Allies did not know that German forces were unprepared for the Russian winter. Additionally, at the end of 1941 there was no reason to believe when winter subsided that Soviet forces would be any more effective against the Germans than they had been the previous year. ${ }^{4}$ As German forces froze on the eastern front, top Nazi officials plotted the details of Hitler's Final Solution at the Wannsee Conference and worked to speedily exterminate Europe's 11 million Jews. ${ }^{5}$ Meanwhile, in the Pacific, the Japanese had launched a series of impressive, swift assaults in the Philippines, Guam, Wake Island, Hong, Kong, Thailand, Burma, and Malaya. By the end of April 1942, all of these areas would be within Japanese hands, leaving the United States and Britain at a serious disadvantage in the Pacific Theatre. ${ }^{6}$ Historical hindsight can easily mislead one into believing that December 7, 1941 was the death nail on the Axis coffin, leading inevitably to an Allied triumph led by American military and industrial might. But when 1941 ended, the situation was very

\footnotetext{
${ }^{4}$ John Keegan, The Second World War (New York: Penguin Books, 1989), 205-208.

${ }^{5}$ Jackson J. Spielvogel, Hitler and Nazi Germany: A History (Upper Saddle River, New Jersey: Prentice-Hall, Inc., 1988), 278-279.

${ }^{6}$ Gary R. Hess, The United States at War, 1941-1945 (Wheeling, Illinois: Harlan Davidson, 2000), 25-34.
} 
dire with victory anything but certain. The United States needed to move, and move quickly. Or, as General George C. Marshall explained, the U.S. military needed rapid access to training and equipment. "All this took time," he wrote, "and time was what we lacked."7

In the midst of this atmosphere of uncertainty and urgency, the military sought to train millions of youngsters in the ways of modern warfare in as short a span of time and effectively as possible. The first step was to get the men to the camps. Individual citizens each received a written notice that they had been chosen by their draft boards to enter the service. The general term given to this written notice was called a "greetings." ${ }^{, 8}$ After receiving the "greetings," West Virginia enlistees reported either to Wheeling or Huntington, where they would be shipped by train to various military reception centers throughout the country. Some of them left home with great fanfare and public adoration. Towns in West Virginia and elsewhere treated their homegrown inductees to parades and parties, sending them off as heroes when they embarked. Local clubs often gave out care packages of chocolates, cookies, cigarettes, chewing tobacco, and sometimes a Bible. ${ }^{9}$ For those who came from rural areas, leaving was a much more intimate experience. James Weekley recalls it as an emotional moment for his family. He did not exit town with fanfare and adoration; only his parents accompanied him to

\footnotetext{
${ }^{7}$ George C. Marshall, Biennial Reports of the Chief of Staff of the United States Army, July, 1 1941, to June 30 1943, 41. Transcribed on http://www.ibiblio.org/hyperwar/USA/COSBiennial/COS-Biennial-2.html.

${ }^{8}$ Lee Kennett, G.I.: The American Soldier in World War II (Norman: University of Oklahoma Press, 1997), 24.

${ }^{9}$ Ibid., 31.
} 
the railroad station. "I watched them drive away," he recalled, "and my mother told me afterwards that my dad started to look back and she told him, 'Don't look back.' In other words, it's another life and go on from there."10

Indeed it was another life. Most veterans, when remembering their wartime experience, remark upon the rapidity of their exit from home and the quick transition to military life. "Before I knew it," Hugh Brown wrote, "I was a soldier. I was at Camp Atterbury, Indiana." ${ }^{11}$ And before they knew it, they were not merely traveling across the nation for the first time; they were seeing their own nation for the first time. Golden Crane, for example, grew up in St. Albans and his family would go into Charleston a few times a year. At the time, Crane, thought Charleston was, "the biggest place I'd ever seen." ${ }^{12}$ It is difficult for the modern American to imagine a pre-television world when the vast majority of citizens had only read or heard about other parts of their homeland. It is even harder to fully appreciate what went through the minds of thousands of young men and women as they peered out the windows of moving trains and witnessed the vast expanse of the United States. Prior to experiencing distant, foreign cultures that seemed exotic, they beheld and remarked upon the distant and (for them) exotic geography and cultures of their own land.

\footnotetext{
${ }^{10}$ James Weekley interview.

${ }^{11}$ Account of Hugh M. Brown, World War II Records, West Virginia and Regional History Collection, Morgantown, WV (Hereafter cited as WVARHC).

${ }^{12}$ Golden Crane interview by Josh Arthur, March 2, 2002, St. Albans, WV, World War II Interviews and Papers, West Virginia Division of Culture and History, Charleston, WV (Hereafter cited as WVDCH).
} 
Most of the training camps were located in the southern states and so, that is where most of the enlistees went. ${ }^{13} \mathrm{~A}$ few days after signing up for the Navy, Earl Richmond left his home in Milton for Huntington where he found himself bound on a train for Miami, Florida. He and his friends stared out the train windows, "and we seen palm trees and everything and said, 'Woo! Where we going?" "14 Others passed through the oil belt of Texas and saw, instead of palm trees, "flames shooting out of the top of oil towers at night." 15 James Weekley also went to Texas and recalled, "We boarded the troop train and went to Shepherd Field, Texas. I'd always heard of Texas all my life. I really wanted to see where the cowboys were, you know, and it's not as pretty country as they would like you to believe." ${ }^{16}$ Don Louden, writing almost daily to his mother, disagreed. "West Virginia has plenty of things Texas doesn't have but that isn't a sunset or sunrise. The last few mornings and evenings they have been beautiful. They have every color and shade you can think of and - well they could never be painted half as pretty as they actually are."17

While West Virginia enlistees may have differed on what they made of the countryside, their letters reveal the scope of what they did not realize about their homeland, even their own state. On the train ride from Fairmont to Huntington, his

\footnotetext{
${ }^{13}$ Kennett, G.I., 44-46.

${ }^{14}$ Earl C. Richmond interview by Matthew Stephenson, May 4, 2002, St. Albans, WV, World War II Interviews, WVDCH.

${ }^{15}$ Don Louden to Phyllis Ann Louden, November 24, 1943, Louden Family Private Collection, Cheat Lake, WV (hereafter cited as LFPC).

${ }^{16}$ James Weekley interview by Franchesca Nestor and Matthew Grotkowski, Bridgeport, WV, November 25, 2004, WVVP.

${ }^{17}$ Don Louden to Phyllis Ann Louden, December 11, 1943, LFPC.
} 
first across his home state of West Virginia, Louden wrote, "So far we have gone through 22 tunnels and 22 bridges. Boy! West Virginia sure is messed up."18 Louden also made several observations not befitting of one supposedly coming from a culturally backward region. He was struck by the poverty he saw elsewhere. "When we woke up this morning we were in Arkansas. It sure is a poor looking state. ${ }^{19} \mathrm{He}$ was also surprised by the lack of consumer goods available in Texas stores as opposed to what one could find in West Virginia. Louden expressed dismay to his mother about the quality of Christmas gifts he was able to obtain for his family. The comments suggest that the author did not come from an isolated or backward culture if for no other reason than he was not very impressed with what he saw or found outside of his home; turning the preconception of the backward hillbilly leaving the mountains to a more awe-inspiring modern world on its head.

Within six months of the U. S. entry in the war, new recruits were entering the training camps at a rate of about 14,000 a day. Many of the camps housed larger populations than any city in West Virginia. Fort Bragg, North Carolina, for example trained 65,000 men at a time, while Fort Benning, Georgia had a 95,000 person capacity. ${ }^{20}$ As the masses of new recruits were rushed into camp, they were given medical examinations, uniforms, shoes, and new haircuts. Most of the West Virginians remember their first few hours as a whirlwind of activity. "The first day

\footnotetext{
${ }^{18}$ Don Louden to Phyllis Ann Louden, November 15, 1943, LFPC.

${ }^{19}$ Don Louden to Phyllis Ann Louden, November 24, 1943, LFPC.

${ }^{20}$ Bennett, G.I., 44-46.
} 
was a busy one for me, as they gave me physical examination, issued the Navy clothing to me and, last but not least, they gave me one of their notorious boat haircuts. You can imagine the confusion which reigns when a large group of men are going through the various phases of this operation." ${ }^{21}$ Many of the boys were also nervous about the medical exams, particularly, those who came from the countryside and had little or no experience with doctors. Some expressed having embarrassment over the so-called "short arm exam," when their genitals would be inspected. ${ }^{22}$ Others waited in anxious anticipation over the numerous shots they would receive. When Jack Birkhimer arrived at Camp Robinson, Arkansas, he was, "shot in the arm with needles "till I thought I looked like a sieve." ${ }^{, 23}$ Some of the boys felt more comfortable when they saw that others shared in the difficulty. "They were giving us shots and I'd never had a shot in my life, in both arms at the same time and some of these big husky athletes were falling over like flies." ${ }^{24}$ Robert McLaughlin wrote, "You was being jabbed in both arms or about the first place they could jab you with needles. When I finished boot camp I was so full of holes they were almost afraid to send me to sea." ${ }^{.25}$ Simon Bailey said his arm was sore for days because of all the shots they gave him. He also had to get used to

\footnotetext{
${ }^{21}$ Account of Simon M. Bailey, World War II Records, WVRHC.

${ }^{22}$ Bennett, G.I., 31-32. The military was very concerned about the spread of venereal disease and went to great lengths to try to identify those infected and prevent the further transmission of STDs. Among other slogans, troops were told, "Flies spread disease, so keep yours zipped."

${ }^{23}$ Account of Jack C. Birkhimer, World War II Records, WVRHC.

${ }^{24}$ James Weekley interview.

${ }^{25}$ Robert E. McLaughlin to Henry Hamilton, September 18, 1942, War History Commission Records (Hereafter cited as WHCR), WVARHC.
} 
taking care of his new clothes. "I, along with everyone else, now had to do my own washing, a skill I have since forgotten." 26

Accompanying the medical exams, new homes, new clothes, and new haircuts, was a new diet. The food in basic training is not known for its gourmet quality, but it was known for its quantity and regularity. Men who were not subsisting on good diets and healthy portions of food due to the Depression were now given three square meals a day. The food, in some ways, may have actually helped soldiers adapt to the cultural shock of their new lives in the army because it was something positive they could reflect on in their letters. A few soldiers certainly complained about the quality of the food, but at least food was now available to them. Some, like Keith Cooke, "thought it was pretty good." ${ }^{, 27}$ Joseph Bertalan wrote of his first army meal, "We expected the food to be terrible. We were ever wrong! We had fried chicken and all the trimmings. It was great, and we could get seconds." ${ }^{28}$ In a letter to a friend, Paul Adkins wrote, "By the way, each day I'm in the Army I get to like it more and more. It isn't exactly as easy as home life - but it's plenty O.K. Talk about eatin' - I really gorge it down here." ${ }^{29}$ One soldier bragged to his mother about the food afforded him on base during the holidays. "I know you have been to that turkey dinner but I bet you didn't eat as much as I do in one meal. I got weighed this evening and I tip the scales at 156.

\footnotetext{
${ }^{26}$ Account of Simon M. Bailey.

${ }^{27}$ Keith Cooke interview by Matthew Shamblin, March 9, 2002, Charleston, WV, World War II Interviews and Papers, WVDCH.

${ }^{28}$ Joseph Bertalan, GI Joe Relives World War II (Morgantown: The Permutation Press, 1998), 7.

${ }^{29}$ Paul Adkins to Anna Johnson, November 29, 1942, Paul A. Adkins Papers.
} 
Not bad for a Mountaineer, huh?" ${ }^{30}$ William Wintz said that when he enlisted he weighed one hundred and fifty pounds, but by the end of basic training he weighed one hundred and eighty five. ${ }^{31}$ Wintz was not alone. Nearly every young man in America who entered the U.S. military during World War II gained weight during basic training, usually ten to fifteen pounds. ${ }^{32}$ Coming from a poverty stricken economy with poor nutrition and poor to no health care, military enlistment had made men from all parts of America the healthiest they had been in their lives. To the soldiers, it was a silver lining in the dark cloud of war. Of course, after they grew accustomed to eating well and often, the soldiers became a bit more finicky. Once Navy shipmen left training for the seas, they sometimes purposely altered the menu. "They served a lot of mutton on the ships and the troops didn't like it." Donnie Smith commented. "The crew from the supply ship would hand the crates over to the guys on my ship. That's how things got transferred over. Well, since our guys knew what was in those crates sometimes they would accidentally let the crates slip out of their hands into the water." 33

All of these transitions served to reinforce the notion that the trainee had entered into a new world. No sooner had the excitement of leaving home, crossing the countryside, and entering the lifestyle of the camps faded than homesickness

\footnotetext{
${ }^{30}$ Don Louden to Phyllis Ann Louden, December 7, 1943, LFPC.

${ }^{31}$ William Wintz interview by Catherine Davis, February 17, 2002, East Bank, WV, World War II Interviews and Papers, West Virginia Division of Culture and History, Charleston, WV (hereafter cited as WVDCH).

${ }^{32}$ Mark P. Parillo, ed., We Were in the Big One: Experiences of the World War II Generation (Wilmington: Scholarly Resources, Inc., 2002), 10.

${ }^{33}$ Donnie Smith interview by Angela Johnson, February 7, 2004, Morgantown, WV, WVVP.
} 
quickly reared its head. As one scholar has put it, "For an American the future has always been important. Suddenly, in the Army, the past becomes important." ${ }^{34}$ Men who began their military journey because of unemployment or patriotism or peer pressure wanted to finish the job for new reasons. Visions of home and family and of simple, everyday things become more pronounced in the memory of each soldier as time and distance from the point of enlistment stretched on. Or as one combat troop simply put it, he was fighting for some of Mom's "blueberry pie., ${ }^{, 35}$

Other studies of soldiers in World War II conclude that this war, more so than any before it in American history, gave the soldier a sense of exile and an "unbridgeable distance from home." ${ }^{36}$ In fact, the phrase, "shipping out" originated during the Second World War. ${ }^{37}$ The long exile from home began at boot camp as soldiers first felt the sting of being away from their loved ones. Unlike previous wars, U.S. military forces were not organized by any regional affiliation. Therefore, large groups of boyhood friends who all signed up together were split up and sent to different camps. Any given unit may only have one or two boys who knew each other beforehand. ${ }^{38}$ Forbes Blair was one of many young men who missed the familiarity of home. "I spent ten and one half weeks recruit

\footnotetext{
${ }^{34}$ Lee Kennett, G.I., 74.

${ }^{35}$ John Morton Blum, $V$ was for Victory: Politics and American Culture During World War II (New York: Harcourt Brace Jovanovich, 1976), 66-67.

${ }^{36}$ Paul Fussell, The Great War and Modern Memory (Oxford: Oxford University Press, 1975), 64.

${ }^{37}$ Ibid., 64-65.

${ }^{38}$ Victor Davis Hanson, The Soul of Battle: From the Ancient Times to the Present Day, How Three Great Liberators Vanquished Tyranny (New York: Anchor Books, 2001), 351.
} 
training at Sampson, New York. This was hard on me, as I had never been away from home. I wrote home every day, and even phoned at least once a week. A buddy of mine was with me and it was much easier with the two of us together." 39 Others were not lucky enough to be in the same company as a friend from home. "During my basic training I became blue," William Rees wrote. "I felt as though I didn't have a friend in the world." ${ }^{40}$ Glen L. Vaughn missed home so much that he could not sleep at night, despite the physical rigors of training. "I could not get to sleep. I just lay there in my bunk and thought of home and the Greenbrier - valley and river." $" 41$

The reality had sunk in; for these mountaineers, their new lives had begun and their old lives were gone forever. The melancholy was not limited to West Virginia soldiers either. During basic training, Harry Slaughter, from Winfield, WV, became friends with Sam Brooks, from New York City. One night Harry was hanging around outside the officers' quarters with a girl when they, "heard this person crying. I look behind this tree and see ole Sam. I said, 'Sam, what's wrong?' He said, 'I'm homesick and if you tell anyone you caught me in this position I will whip you." ${ }^{, 42}$ Thus, the transition from civilian to soldier began with the simple introduction to a new environment. The training camps were mostly far from home while the military clothing, haircuts, and food reinforced

\footnotetext{
${ }^{39}$ Account of Forbes Blair, World War II Records, WVRHC.

${ }^{40}$ Account of William Rees, World War II Records, WVRHC.

${ }^{41}$ Unpublished memoirs of Glen L. Vaughn, 3-4, Glen L. Vaughn Papers, WVRHC.

${ }^{42}$ Harry Slaughter interview by Brett Wooten, Winfield, WV, April 29, 2002, World War II Interviews and Papers, WVDCH.
} 
this transition. But simply hurling young men by the thousands into military camps does not turn them into fighters. For this transition to be successful, the men would need training and military discipline.

Deconstructing the Individual

When Americans arrived in foreign lands, Europeans and Asians alike were quick to believe that the soldiers from the New World behaved in a way unique to other soldiers. They laughed and talked as they marched through town. They wore their helmets tilted to one side and were sometimes unshaven. They slouched in seats at restaurants. Groups of GIs burst into English and Australian pubs as though they owned the place. When an American jeep sped by, it was common to see men driving with one arm dangling over the top of the steering wheel, or soldiers with their feet propped up in the backseat. ${ }^{43}$ When William Wintz, from East Bank, WV, and his best friend marched into a liberated French town, they each took off their helmets and donned a couple of top hats that they bought in Paris. ${ }^{44}$ Officers in foreign armies particularly noted that American soldiers had a "loose and relaxed" way of marching. Or as a Czech villager commented to an

\footnotetext{
${ }^{43}$ Bennett, G.I., 81-83.

${ }^{44}$ William Wintz interview.
} 
American officer when a division of U.S. troops strode through town, "They walk like free men." ${ }^{45}$

Individualism is often assumed to be one of the most distinguishable features of any society where democracy has existed for generations. The U.S. military was faced with the task of dealing with millions of civilians who, because they were so accustomed to individual liberty, may not submit to authority readily enough for the military to be successful in the field. In the minds of most military thinkers of the time, this mentality of freedom that accompanied the U.S. soldier was a hindrance to creating an effective fighting force. Most of the other national armies involved in the war did not have the problem of overcoming individualism within their troops, particularly in those societies who did not champion free thinking. The Japanese, for example, began grooming soldiers from a very early age. Beginning in the 1920s, school curriculum in Japan was tailored to prepare young boys to enter into military service. War was stressed in every subject. In science classes, students were taught about artillery, submarines, and military sanitation. In math, they were to do "calculations about military matters." In history, they learned of the special characteristics of the Yamato Race and the divinity of the Emperor. They sang national war songs in music class. When students passed teachers in the hallway or even in public, they were required to

${ }^{45}$ Bennett, G.I., 81-83. 
stop and give a military salute. ${ }^{46}$ By the time the boys reached the Japanese training camps, they were better groomed to obey orders and make the transition to violence than their American counterparts. Once the actual training began, privates were subjected to regular and systematic beatings from officers with bamboo sticks and the leather straps of the officers' swords. Other examples of teaching submission to the privates included making them wash the backs of their NCOs and untying their officers' shoes at the end of the day. ${ }^{47}$ By contrast, many Americans called for the court martial of General George S. Patton when he slapped a soldier. ${ }^{48}$

The point is that in 1941, the United States was not only behind its enemies in mobilization and deployment, but also they dealt with a population of new recruits who were very likely to champion individualism and resent authority. In order to eradicate the spirit of the individual, the U.S. military purposely designed basic training as a type of "intensive shock treatment rendering the trainee helplessly insecure in the bewildering newness and complexity of his environment. ${ }^{, 49}$ This design explains why men from the same towns were broken up, so they could not find sanctity with friends from home. The new haircuts, clothes, and surroundings also helped reinforce conformity and make the

\footnotetext{
${ }^{46}$ Sabura Ienaga, Japan's Last War: World War II and the Japanese, 1931-1945 (New York: Pantheon Books, 1978), 325-328.

${ }^{47}$ Ibid., 53; Frank Gibney, translated by Beth Cary, Senso: The Japanese Remember the Pacific War (Armonk, New York: Little, Brown, and Company, 1995), 54-56.

${ }^{48}$ Adams, The Best War Ever, 96-97.

${ }^{49}$ Quoted in Gerald Linderman, The World Within War: American's Combat Experience in World War II (New York: The Free Press, 1997), 186.
} 
individual feel small. The goal was to break individuals down to "powerlessness so that their collectivity, their units, might become powerful. ${ }^{, 50}$ In short, the military wanted to deconstruct individual identity and built a collective fighting identity. Officers belittled the privates by shouting insults at them. One West Virginian noted, "The officers are pretty tough - they know every cuss word in the book and sure use them all on us." ${ }^{51}$

Failure to conform to the group mentality in basic training led to punishments such as having weekend passes revoked, latrine duty, fines, or simply an inordinate amount of pushups. ${ }^{52}$ Some punishments were more creative. One private who was caught throwing his cigarette butt on the ground was told by his sergeant to give it a decent burial and forced to dig a six foot hole for the butt. Other privates were punished by being forced to clean floors with toothbrushes. ${ }^{53}$ All of these methods intended to "rid the conscript of civilian preconceptions about his rights and personal freedom" and get him to understand that he is nothing more than, "a chattel, hopefully a proud chattel, but a chattel all the same, and therefore is dispensable as the ships and tanks and guns and ammo he himself serves and dispenses. ${ }^{, 54}$ One mountaineer remarked that the cumulative effect of

\footnotetext{
${ }^{50}$ Ibid.

${ }^{51}$ Paul Adkins to W.J. Drosick, November 18, 1942, Paul A. Adkins Papers, WVRHC.

${ }^{52}$ Paul Fussell, Wartime: Understanding and Behavior in the Second World War (New York and Oxford: Oxford University Press, 1989), 80.

${ }^{53}$ Linderman, The World Within War, 187.

${ }^{54}$ Quoted in John Ellis, The Sharp End: The Fighting Man in World War II (New York: Charles Scribner's Sons, 1980), 7.
} 
the new environment and the discipline made basic training, "both terrifying and interesting. ${ }^{, 55}$

But did it work? Were military officers able to effectively eliminate individualism and get the privates to obey orders without question? The answer is both yes and no. American soldiers submitted enough to eventually become a very successful fighting force while still maintaining their own individual and cultural identities. While soldiers, particularly in battle, looked to officers for orders and conformed enough to fight effectively, outside of combat situations soldiers often only followed orders with great reluctance. ${ }^{56}$ One West Virginian, writing a year after the war, recalled military discipline with a touch of bitterness. "Little did I know that I was being 'Shanghaied' into twenty-three months of obeying orders." ${ }^{57}$ Other mountaineers agreed. "We were segregated into two classes officers and white trash. ${ }^{, 58}$ The recruits often made their own decisions about what orders they felt were important or not. Unimportant or "ticky-tack" commands were called "Mickey Mouse" orders. The men often practiced minor resistance to these orders, such as stopping work whenever the "brass" was not around and quickly jumping into activity whenever an officer approached. ${ }^{59} \mathrm{~A}$ few of the

\footnotetext{
${ }^{55}$ Account of Grace Kennedy, World War II Records, WVRHC.

${ }^{56}$ It appears as though the stress of combat actually made soldiers much more willing to obey their officers because, in the confusion of battle, they wanted someone to tell them what to do. In cases where officers "froze up" in the face of combat, the strongest personality in the platoon often took charge, a phenomenon that appears to be the product of privates retaining individual initiative. Ellis, The Sharp End, 188-192.

${ }^{57}$ Account of R.S. Reed, World War II Records, WVRHC.

${ }^{58}$ Account of Stanley Reckart, World War II Records, WVRHC.

${ }^{59}$ Linderman, The World Within War, 187.
} 
privates were outright defiant. Harry Slaughter, from Winfield, WV, told a story about training exercises with tear gas. "[The officer] would go up to a building and throw tear gas into it. We were supposed to respond correctly but half of us didn't have gas masks with us so we ran out the door." The officer then ordered the men to go back into the building. When they refused, he threatened to court martial Slaughter and the others. "He said he could court martial me for disobeying an order. I said, 'yeah Captain, I could give you something to really court martial me for.' Then he backed off. ${ }^{\prime 60}$ Such individualism would have been nonexistent in most of the other major armies of the war. Could one imagine Soviet or German privates speaking to their officers in such a way? Complicating matters further was the fact that officers in the United States were more reluctant than other militaries to be overly harsh with trainees because of public scrutiny. Newspapers interviewed soldiers and wrote commentaries on the harshness of boot camp. Additionally, officers were inundated with critical letters from mothers, wives, and sweethearts telling them not to be "too hard on the boys." The officers, who mostly came from similar backgrounds as the privates, often obliged. ${ }^{61}$

In the final analysis of individuality and training, the American soldiers who "walked like free men" across Europe and the other continents, had to some degree, effectively resisted the military's efforts to destroy the individual. This is partly due to each trainee's background in a free society, and because of this free

\footnotetext{
${ }^{60}$ Harry Slaughter interview.

${ }^{61}$ Kennett, GI, 66-68.
} 
society, officers were restricted in the amount of discipline they could enforce. In other armies where democracy was not a part of the culture, there were no such restrictions and discipline was severe. With the World Wars in hindsight, some more recent military thinkers have argued that the American individualism that persisted in the soldiers actually made the men better fighters. In this view, soldiers from democratic societies were more innovative and adaptive in combat because they came from a freethinking culture. Those who come from totalitarian societies could not adapt and improvise as well because of the rigid system of following all orders to the letter. ${ }^{62}$ This idea of individualism producing adaptability in battle may hold some validity. However, it is very difficult to discern exactly how effective individualism may have affected combat in a modern industrial war with weapons of mass destruction. Nonetheless, it is important to recognize that Americans still retained a measure of individual identity despite the military's best efforts. One soldier from Morgantown, WV summed it up well in a letter from training camp. "You know, at heart I am still a civilian (but don't breathe a word of this to the MPs)." ${ }^{, 63}$

Constructing the Fighting Spirit

\footnotetext{
${ }^{62}$ Victor Davis Hanson, Carnage and Culture: Landmark Battles in the Rise of Western Power (New York: Anchor Books, 2001), 356-360.

${ }^{63}$ Gibson Fair to R.J. Friant, January 23, 1945, Friant Collection, West Virginia War History Commission Records (hereafter cited as WVWHCR), WVARHC.
} 
In 1944, a U. S. Army promotional film entitled Classification of Enlisted Men sought to explain the processes by which the army determined where, and in what capacity, each enlisted soldier was sent during his military service. In the film, an army evaluator interviewed several new recruits in order to match their military assignments with their backgrounds. For example, a young man who worked as a tractor driver for a lumber company was assigned to a tank division. Upon finding out that another man previously worked as a telephone lineman, the evaluator sent him to the Signal Corps. The last man interviewed was a mountaineer who, when asked what his favorite hobby was, instantly replied, "shootin'!" He was then sent to the infantry. ${ }^{64}$

As the Armed Forces worked to destroy individual identity, they sought to construct a fighting spirit within their soldiers, particularly within the infantry. The infantrymen, of course, are forced to endure the bulk of the fighting in any war. Military planners were therefore beset with the quandary of determining which recruits to send to the infantry. Would certain recruits make better fighters than others? If so, how could the Armed Forces make an accurate determination? The above example might lead one to conclude that the military believed mountaineers were better suited for combat because of their rugged, gun-toting, rural background. Newspapers and war correspondents from across the nation reinforced a similar notion. Whenever reporters singled out GIs to write about, the

\footnotetext{
${ }^{64}$ Lee Kennett, GI: The American Soldier in World War II (Norman: University of Oklahoma Press, 1997), 34-36.
} 
vast majority of them were from rural America. The soldier's lineage was often brought up, and phrases like "he was born of a long line of pioneers" or "of pioneer stock" or "proud of his country roots" were very common. ${ }^{65}$ It seems as though reporters looked to embellish the idea of an American frontier spirit that had been lying dormant in American society and was now being reawakened by the war, much to the chagrin of the Axis Powers. It would also seem then, if Appalachians, living in a supposed cultural vacuum of the mountains, should more easily be able to tap into the American frontier spirit that produced so many rugged freedom fighters in our past. Dwight Eisenhower evidently thought so; or at least he was willing to say that he thought so. Speaking at West Virginia University in 1947, Eisenhower claimed that West Virginia soldiers have "proved themselves spiritual heirs of the pioneers" and, as a result, had risen to become "valiant defenders of liberty." ${ }^{, 66}$ All of this rhetoric suggests that Americans were searching to construct for themselves national characteristics that would help instill confidence in the populace, legitimize a military spirit with the soldiers, and ensure eventual victory. The supposedly savage and backward hillbilly, who had been a danger to social progress in previous decades, now was transformed into a rugged mountaineer, willing to fight and prepared by his rural mountain roots to quickly adapt to war.

\footnotetext{
${ }^{65}$ Blum, $V$ was for Victory, 59.

${ }^{66}$ Eisenhower Convocation Address, transcript, WVARHC.
} 
It is impossible to know how many Appalachians were sent to the infantry because it was thought their culture gave them more potential as fighters. In order to access an enlistee's fighting potential, the military used a written questionnaire called the Army General Classification Test (AGCT) and a psychiatric interview known to soldiers as the Ink Blot Test, because they were asked to give an interpretation of various ink blot formations on white cards.$^{67}$ This was intended, as the film Classification of Enlisted Men pointed out, to provide officers with a detailed evaluation of each soldier and help determine who was sent where. However, the sheer volume of men who enlisted after Pearl Harbor combined with the urgent wartime situation made it impractical to give everyone a thorough examination. At times, psychiatrists were so rushed and overwhelmed with numbers that recruits were asked three or four questions and sent on their way. ${ }^{68}$ The AGCT and the Ink Blot Tests may have been somewhat effective in a situation where ample time and attention could be given to every single recruit, but as with many other things in war, what works efficiently on paper does not necessarily work in reality. In the end, recruits were sent to various places in the military not because of their mental "readiness for war" or their physical stature, region or cultural background. Instead, the individual's level of education appears to be the biggest factor. Those who were more educated were sent to operate machines, work on bases, intelligence gathering, and so forth. Those without a

\footnotetext{
${ }^{67}$ Kennett, GI, 29-30.

${ }^{68}$ Ibid., 34-36; Ellis, The Sharp End, 2.
} 
strong educational background were most often sent to the infantry. This, in turn, meant that infantry units' ranks were filled with rural Americans since they often had less formal education than urban Americans. ${ }^{69}$ African-Americans served as the only major exception to this rule, as prevailing racial stereotypes insisted that they would not make good combat soldiers. Instead, most African-Americans were deployed away from the front lines and utilized as cooks, construction workers, or in general supply service. ${ }^{70}$

It appears then, as though the military did not single out mountaineers as fitted especially for the infantry. Although, it is safe to assume that a higher proportion of mountaineers probably went to the infantry than from urban regions due to the lack of a strong educational system in Appalachia in the 1940 s. $^{71}$ It is also conceivable that the military elite believed Appalachians to be more expendable because of their apparent lack of education and supposed cultural ineptitude and, thus, sent more to the infantry. ${ }^{72}$ Regardless, psychological tests and cultural background failed to determine how ready any individual may have been for the rigors of combat. Psychiatrists had neither the time nor means to properly predict who would make good fighters and who would not. Or as General

\footnotetext{
${ }^{69}$ Ellis, The Sharp End, 2-4.

${ }^{70}$ Christopher Paul Moore, Fighting for America: Black Soldiers - the Unsung Heroes of World War II (New York: One World Books, 2005), 25-27, 132.

${ }^{71}$ Otis Rice and Stephen Brown wrote that the Great Depression created a "crisis in public education" in West Virginia. Dozens of schools closed down, terms were shortened, and teachers left the schools because they weren't paid. During this time, less than 50\% of West Virginia high school graduates went on to college. Otis Rice and Stephen Brown, West Virginia: A History (Lexington: University of Kentucky Press, 1993), 247-248.

${ }^{72}$ Ellis, The Sharp End, 2-4.
} 
Lewis B. Hershey said, "I haven't seen a draft questionnaire yet in which the guy said he shot people for a living."

Clearly, military leaders had no intention of completely trusting in a private's "pioneer stock" alone to prepare him for battle. To achieve this readiness, the Armed Forces relied on extensive physical training and ideological indoctrination. The first step towards turning men into fighters was with simple, rigorous physical conditioning. Most of the days in boot camp were spent drilling, marching, and running. The recruits crossed ditches and scaled walls on obstacle courses. They marched double time up hills, if any could be found in the general vicinity. Predictably, most of the privates did not like it, particularly when they exercised in extreme weather. ${ }^{74}$ Even the mountaineers, who according to preconceptions should have been more at home outdoors, complained along with the rest of the troops. Don Louden, of Fairmont, WV, dreaded marching a "Texas Mile" every morning. ${ }^{75}$ Gibson Fair wrote home to his family in Morgantown, WV, during training and was uncomfortable with the "miserable conditions" of training outdoors. “The G.I. way isn't anything to brag about, living this close to Mother Nature." 76

Aside from physical conditioning, the trainees learned to throw grenades, fire and reload their weapons, and were given some instruction in hand to hand

\footnotetext{
${ }^{73}$ Kennett, GI, 37.

${ }^{74}$ Ibid., 56; Stephen Bull and Gordon L. Rottman, Infantry Tactics of the Second World War (Oxford: Osprey Publishing, 2008), 22-24.

${ }^{75}$ Don Louden to Phyllis Louden, December 19, 1943, Louden Family Collection.

${ }^{76}$ Gibson Fair to R.J. Friant, March 28, 1944, Friant Collection, WHCR.
} 
combat. ${ }^{77}$ Presumably, mountaineers would have been more familiar with guns than other Americans, but this was not necessarily the case. Joseph Bertalan found himself completely unprepared for combat drilling, "I had never owned or shot a gun before basic training." ${ }^{, 78}$ For Harry Slaughter, the kill or be killed mentality of hand to hand combat training stood out most vividly:

We were given a quick, I can't say training session, quick look at combat training. We had one fellow who taught you how to kill a man. I remember very vividly. He said, "I don't care if it is a fight on the corner or where it is, that other person is out to kill you." The attitude you have to develop is the same ... he showed you with a broomstick, you could kill a man just like that. If you use that broomstick the right way you could kill him. He gave us a certain amount of training with a knife. ${ }^{79}$

Bayonet training was also featured significantly in boot camp. Even though military planners assumed that modern war had rendered the bayonet virtually obsolete, it was still used in order to stir up aggression and ferocity in the infantry. This was not physical training as much as it was mental conditioning. Officers hoped that thrusting a sharp bayonet into a straw-filled sack would mentally prepare the infantryman for the killing that was to come. ${ }^{80}$ The Japanese, by contrast, went a bit further while trying to instill a fighting spirit with their men.

\footnotetext{
${ }^{77}$ Bull and Rottman, Infantry Tactics, 23.

${ }^{78}$ Joseph Bertalan, GI Joe Relives World War II (Morgantown: The Permutation Press, 1998), 10.

${ }^{79}$ Harry Slaughter interview.

${ }^{80}$ Bull and Rottman, Infantry Tactics, 24-25.
} 
By the late 1930s, they forced trainees to charge and bayonet live Chinese POWs who were tied to poles. ${ }^{81}$

Boot camp also attempted to get the trainees accustomed to the sounds of war. Machine guns fired live rounds over the privates' heads as they crawled under barbed wire. In a few bases, troops had to dig their own pit and crawl into it as a tank ran over the pit. Pyrotechnic "thunder flashes" were occasionally used to mimic artillery fire. At times, the recruits were exposed to real demonstrations. ${ }^{82}$ As one letter from a West Virginia trainee shows, a background in mountain living does not prepare one for the sights and sounds of modern war. "We went into the [training] village and watched a demonstration of high explosives in the morning and every time a charge went off I just about had an accident (guess which kind)." 83

When the privates were not getting into physical shape the military attempted to mold them with ideological indoctrination and prepare them for war with lectures and films. Trainees watched films ranging from straight Allied propaganda to instructional videos on operating artillery or even radios. ${ }^{84}$ Not surprisingly, many soldiers felt that the lectures and classes took away from any glamour associated with soldiering, making training, "more difficult and less

\footnotetext{
${ }^{81}$ Gibney, Senso, 65.

${ }^{82}$ Bull and Rottman, Infantry Tactics, 30-31.

${ }^{83}$ Don Louden to Phyllis Ann Louden, January 2, 1944, LFPC.

${ }^{84}$ Kent Roberts Greenfield, Robert R. Palmer, and Bill I. Wiley, of the Historical Section, Army Ground Forces, The United States Army in World War II: The Army Ground Forces and the Organization of Combat Troops (Washington, D.C.: Historical Division, Department of the Army, 1947), 410-412.
} 
exciting. ${ }^{, 85}$ Even less surprising is that an Army study after the war showed that instructional videos turned out to be "of very limited value in the field of combat." ${ }^{86}$ When the fighting began, most soldiers simply forgot most everything they were taught in this format. ${ }^{87}$ What they did not forget was the ideological training. The military, along with the federal government, used a combination of films, lectures, posters, and other propaganda in order to convey the justification of the Allied cause in the war while simultaneously dehumanizing the enemy. The best known of these films is the Frank Capra Why We Fight series. ${ }^{88}$ The films portray the war as conflict between the free world and a slave world. Stereotypes, both national and cultural, were used to paint a picture of German and Japanese societies as inherently aggressive and militaristic. Soldiers were also inundated with posters depicting Germans with fangs and Japanese as yellow monkeys. ${ }^{89}$ The cumulative effect of this effort by the military certainly resonates in the letters and written accounts of West Virginia soldiers, who occasionally used phrases such as "Japs" and "yellow monkeys" when referring to the Japanese, while some of the accounts refer to the Germans as evil and "devilish." This seems to be both a reflection of the prevailing ethnic views in America at the time and suggests that

\footnotetext{
${ }^{85}$ James Weekley interview.

${ }^{86}$ Greenfield, Palmer, and Wiley, The United States Army in World War II, 412.

${ }^{87}$ Ibid., 413.

${ }^{88}$ John W. Dower, War Without Mercy: Race and Power in the Pacific War (New York: Pantheon Books, 1986), 14-17.

${ }^{89}$ Ibid., 14-25.
} 
the military was at least partially successful in convincing the troops of the righteousness of their cause, and that the enemy deserved no mercy. ${ }^{90}$

The military training given to U.S. citizens during the war served its purpose in that it sold the necessity of the war and that working cohesively as a military unit was essential to success on the battlefield. However, the training did not destroy individualism within the soldiers. Not only did soldiers resist authority, they were subjected to stereotypes that were associated with their homes. As we shall see, during boot camp, the trainees often reacted to these stereotypes by either refuting preconceptions others may have of them or by latching their own personal identity with that of their own region within the country.

\section{Clinging to Regional Identity}

In West Virginia, the hillbillies are always somewhere else. When questioned about hillbillies or rednecks or other stereotypical characteristics associated with Appalachia, many urban West Virginians (or at least urban in the Appalachian sense, meaning that they live in a town) will often agree with outside observers that there is a measure truth in cultural stereotypes. However, urban West Virginians will try and distance themselves from the clichéd portrayals

\footnotetext{
${ }^{90}$ Among many others, see the accounts of Robert Urbas, Ray Silver, Rudy Barie, and Elmer Henerdshot, WWII Veteran's Service Experience Records, WVARHC.
} 
found in the national media, books, film, and certain sectors of academia.

Residents of Charleston, Wheeling, Martinsburg, or any of the other towns in the state will often point to other West Virginians who live in nearby rural areas and categorize them in the similar fashion to a New York journalist. To paraphrase the idea, referred to by John Alexander Williams as the "Two Appalachias," someone who lives in Huntington might say, "I am not a hillbilly or a redneck, but those people living a few miles outside of town certainly are." $" 91$

One of the best descriptions of this urban/rural identity conflict (or Two Appalachias) can be found in John O'Brien's book At Home in the Heart of Appalachia. O'Brien was the son of a native West Virginian who became one of the many Appalachian out-migrants in post World War II era who fled the region looking for work in the big urban centers of America. In O'Brien's case, his father ended up in Philadelphia. After he grew up, O'Brien moved his family back to West Virginia in hopes of reconnecting with his family's cultural heritage. They settled in Franklin, the county seat of Pendleton County. ${ }^{92}$ O'Brien quickly discovered an undercurrent of strong cultural tension between the residents of Franklin and those in the surrounding North Fork Valley. People in Franklin considered the more rural folk of North Fork to be the genuine hillbillies of the area, while those of North Fork saw the people in Franklin as snobbish and elitist. Hostility between the small urban and rural communities spilled over into

\footnotetext{
${ }^{91}$ John Alexander Williams, Appalachia: A History (Chapel Hill: University of North Carolina Press, 2001), 144-145.

92 John O'Brien, At Home in the Heart of Appalachia (New York: Anchor Books, 2001), 27-46.
} 
everything from county politics to road constructions to heated high school sports rivalries. ${ }^{93} \mathrm{O}$ 'Brien attributes this social tension to the economic imbalance caused by the industrial age. The families in Franklin, as in other small industrial towns around Appalachia, prospered more from the coal and timber industries and used industrialization as a means of seizing political and economic control of the county. Rural residents resented this control and therein lay the social tension. ${ }^{94}$ The validity of O'Brien's explanation is not the purpose of my mentioning his book but rather, I include it because of the validity of his cultural observation. Just as mainstream America has historically looked down on Appalachians as culturally inferior, one can easily find same dynamic being recast on a smaller scale within Appalachian communities. In the eyes of many Franklin residents, they did not deserve the hillbilly label, but the people in North Fork did.

While residents within certain parts of West Virginia believed themselves to be culturally different from other parts of the state, observers outside of Appalachia made no such distinctions. The fact that someone hails from Franklin while someone else calls North Fork home becomes irrelevant as soon as both residents cross the state line. This fact became quickly apparent to all the young men who left their homes for service in the Second World War. In a time when many citizens had never traveled out of their home state and had more closely identified with a county or town, GIs entering the service found that their identity

\footnotetext{
${ }^{93}$ Ibid., 165-168.

${ }^{94}$ Ibid., 169-175.
} 
was now tied with their state and region, no matter what place within the state they called home. As Studs Terkel put it, "There was another first in the lives of GIs. Young kids, who had never wandered beyond their precinct of their native city or their small hometown or their father's farm, ran into exotic places and exotic people. As well as one another whom they found equally exotic." 95 While trying to create a formidable fighting force, the United States military had to deal with more than individualism, they had to deal with the ethnic and regional diversity of America. In fact, the United States forces were among the most, if not the most, ethnically and culturally diverse of all the belligerents in World War II. There was no other alternative, really, because there was nothing close to a uniform culture or ethnicity in the United States. ${ }^{96}$ This is perhaps one of the main reasons why American journalists tried to emphasize the "pioneer" roots of rugged, freedom loving individualism within the troops; they wanted to construct some form of cohesive American identity. If they could not do so ethnically, they could try to do it ideologically. While the Germans and Japanese touted their master races, the Americans touted their master ideals.

Military planners hoped that American ideals would be strong enough to glue together the various cultures and ethnicities overrunning their camps from

\footnotetext{
${ }^{95}$ Terkel, The Good War, 8.

${ }^{96}$ Niall Ferguson, The War of the World: Twentieth Century Conflict and the Descent of the West (New York and London: Penguin Books, 2006), 516-518. The Allies were actually far more diverse than the Axis. Ferguson points out that the Germans, Italians, and Japanese were not merely fighting the Americans, English, and Russians, they were fighting their empires. In addition to their own ethnic groups, the English also put Indians and Africans on the field. Ethnic Russians only made up 58\% of the Soviet fighting force, and the United States fighting force was a complete hodgepodge of ethnic diversity.
} 
1941 onwards. In the end, the idea of America proved more powerful than the sum total of regions and groups that made it up. However, the various groups and individuals that converged on the training camps continued to maintain their own identity, just as they were quick to recognize the uniqueness of others around them. Edwin Berry of Huntington, WV, was among those to remark upon the differences. A couple of the boys in his company were from Brooklyn. Concerning their speech he said, "It was a strange language to me." ${ }^{, 97}$ Meanwhile another trainee from New York thought that "the southerner was an exotic creature." ${ }^{98}$ As indicated in their letters, some of the mountaineers thought that the people in the military were not as friendly as people from West Virginia, and they felt strange around these new individuals. One man wrote, "There are a lot of Italians, French, and Jews." ${ }^{99}$ This observation was rather typical. The ethnicity of other soldiers within the U.S. military was duly noted in letters. Soldiers remarked about the Lithuanian boy from Massachusetts or the Polish boys from Pennsylvania, or the Hungarian from Nevada while other West Virginians were simply called West Virginians regardless of ethnicity. ${ }^{100}$

Due to a combination of factors: a new environment, being away from home for the first time, and surrounded by people who seemed at first to be very different, West Virginians bonded with other West Virginians. Whenever one

\footnotetext{
${ }^{97}$ Edwin C. Berry interview by Charles A. Nichols, May 7, 2002, World War II Interviews and Papers, WVDCH.

${ }^{98}$ Terkel, The Good War, 6.

${ }^{99}$ Don Louden to Phyllis Ann Louden, November 26, 1943, LFPC.

${ }^{100}$ Patrick Gainer to his wife, August 9, 1945 and August 31 1945, Patrick Ward Gainer Papers, WVARHC.
} 
West Virginian ran into another it was an event worth writing home about. Even officers would spend a long time talking to a private if they were both from the Mountain State. ${ }^{101}$ This was not a unique phenomenon. During training, soldiers everywhere tended to bond with others who were either from their home state or region. Southerners found more in common with other southerners, Midwesterners with other Midwesterners, and so forth. In training they often stuck together, teased boys from other regions, and defended one another. ${ }^{102}$ Usually, West Virginians found themselves the butt of stereotypical jokes. According to Nick Oliver, who was an Italian-American from West Virginia, there was a certain comradely between West Virginia soldiers because they were all called hillbillies. ${ }^{103}$ Herbert Stover served in a company with several other West Virginians and said "we [West Virginians] were all made fun of because of where we were from." ${ }^{104}$ Albert Taylor was teased by his shipmates because he sang "hillbilly music." 105 Junior Gordon Arnold had similar memories. "They called me hillbilly and all the rest." During one of his furloughs, Arnold spent a few days in New York with the family of another private. One of the private's friends asked him what life was like in western Virginia. Arnold replied, "Hey buddy, West Virginia has been a state since 1863. You think West Virginia's backwards? Ugh!

\footnotetext{
${ }^{101}$ Don Louden to Phyllis Ann Louden, November 26, 1943, May 19, 1944, and May 22, 1944; Patrick Gainer to his wife, August 9, 1945, Patrick Ward Gainer Papers, WVARHC.

${ }^{102}$ Kennett, G.I., 60-61.

${ }^{103}$ Nick Oliver interview by Ashle Strickler and William Shalhoub, November 16, 2004, Morgantown, WV, WVVP.

${ }^{104}$ Herbert Dale Stover interview by Matt Stover, November 19, 2004, Eccles, WV, WVVP.

${ }^{105}$ Albert Beck Taylor interview by Matthew Mitchell, March 21, 2002, World War II interviews, SDCH.
} 
Somebody doesn't know their geography." ${ }^{, 106}$ George Kovach recalled that some of the soldiers from New York asked him if he "had to swing on grapevines at the head of my hollow to get home."107 Things were the same for Roy Cashdollar, who flew B-17 Bombers over Europe. "You may go into town and someone says 'Where are you from?' and they come up with a wise crack like, 'Surprised your smart enough to be in the Air Corps.' Little things like that. West Virginians always get that. I don't understand it. They would say things like, 'We didn't think you could read or write.",108 Phil Meadows said that because he was from West Virginia, "they thought that I could shoot."109 The above examples show that one young man from Kanawha County who may have considered himself culturally distinguishable from someone in Boone County found that when he went to training camp, he became just another West Virginia hillbilly. These mountaineers were associated with Appalachia in general and thus, went from a local identity to an Appalachian one.

Throughout the history of Appalachian Studies, stereotypes associated with the region have almost exclusively been attributed to outside influences. The prevailing viewpoint, as asserted by Allen Batteau, Henry Shapiro, John Alexander Williams, David E. Whisnant, Jane S. Becker, and others, claims that

\footnotetext{
${ }^{106}$ Junior Gordon Arnold interview by Jackie Ayres, November 9, 2004, Morgantown, WV, WVVP.

${ }^{107}$ George Kovach interview by Matthew Chambers, December 3, 2004, Morgantown, WV, WVVP.

${ }^{108}$ Roy Clem Cashdollar interview by Troy McMahan, November 29, 2004, Chester, WV, WVVP.

${ }^{109}$ Phil Meadows interview by Glen Toler, December 3, 2004, Morgantown, WV, WVVP.
} 
the idea of Appalachia (and the stereotypes associated with it) was a myth imposed upon the inhabitants of the Appalachian Mountains by mainstream America, industrialists, and writers. As the United States became more multicultural and less Anglo-Saxon during the Industrial Age, writers, missionaries, and others created the idea that the pioneer traditions of rugged, freedom loving, individualist Americanism could still be found in the isolated mountains of Appalachia. Thus, the mountaineer stereotype was imagined in the minds of mainstream America. When it came time to exploit the natural resources of Appalachia, industrialists and journalists created a partially-dehumanized version of the mountaineer - the uncivilized, feuding hillbilly and redneck. The Appalachians, then, were transformed from humans to stereotypes. According to this viewpoint, they did not control their own image. Much of Appalachian scholarship of the past twenty-five years has sought to deconstruct these imposed images and recast what is commonly referred to as the "Invention of Appalachia." $" 110$

Certainly, recent studies have shown that outside influences have played an important role in shaping the national perception of Appalachia, just as in other mountain cultures. But is it really safe to assume that because "city folks always

\footnotetext{
${ }^{110}$ See Henry D. Shapiro, Appalachia on our Mind (Chapel Hill: University of North Carolina Press, 1978); David E. Whisnant, All That is Native and Fine, (Chapel Hill: University of North Carolina Press, 1983); Jane S. Becker, Selling Tradition: Appalachia and the Construction of an American Folk, 1930-1940 (Chapel Hill: University of North Carolina Press, 1998); Williams, Appalachia: A History.
} 
control the media"111 that mountaineers have no control over their own image and are mere victims of outside portrayals? I do not believe so. Throughout history, mountaineers from Appalachia and elsewhere have perpetuated their own stereotypes when it benefited them to do so. One obvious example comes from the West Virginia State Seal. Adopted by the state congress in 1863, and also used on the State Flag, the State Seal features two mountaineers standing side by side with a stone between them. The mountaineer on the left, representing agriculture, boasts a long beard, is dressed in hunting garb and holds an ax. The one on the right is a miner wielding a pickax who represents the transition to industrialism. But the most interesting portion of the seal is found beneath the feet of the two mountaineers. Two rifles cross at the barrels and, resting directly between them, is a Phrygian cap. According to Joseph H. Diss Debar, the seal's designer, the rifles and cap symbolize that "freedom and liberty were won and will be maintained by force of arms." ${ }^{, 12}$ Below the rifles and cap, one finds the Latin phrase Montani Semper Liberi, which translates, "mountaineers are always free." Interestingly, Diss Debar grew up in the Swiss Alps and migrated to western Virginia in the 1830s. Montani Semper Liberi had been traditionally used by Swiss mountaineers to express "their independence of spirit." It was later adopted as the official state motto of West Virginia. ${ }^{113}$

\footnotetext{
${ }^{111}$ Williams, Appalachia, 145.

${ }^{112}$ Bernard L Allen, "Joseph H. Diss Debar," The West Virginia Encyclopedia, Ken Sullivan, ed., (Charleston: West Virginia Humanities Council, 2006): 197; "State Seal," The West Virginia Encyclopedia: 679.

${ }^{113}$ Rachelle Bott Beckner, "Montani Semper Liberi," The West Virginia Encyclopedia: 495.
} 


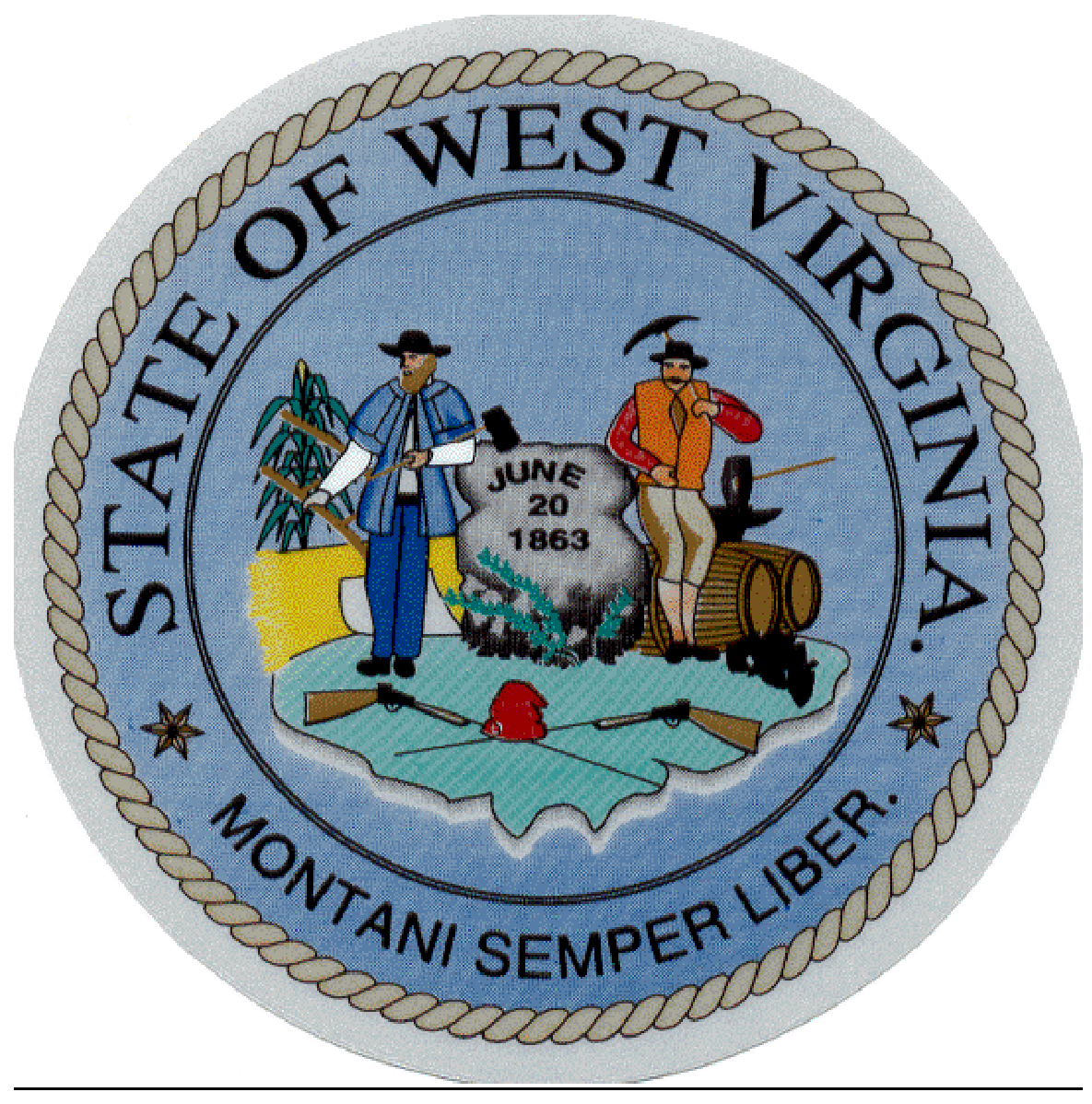

The West Virginia State Seal ${ }^{114}$

With a clear knowledge of the meaning behind the State Seal, a couple of thoughts become readily apparent. First, the state government of West Virginia was embracing the very ideals (freedom-loving, independent, and violence) which have been used as mountaineer stereotypes throughout Appalachian history. To put it another way, can modern scholars really blame the color writers of the 1870 s and 1880s for portraying Appalachia in a manner that mirrors what is proudly

${ }^{114}$ Image found at http://www.anyflag.com/state/wvirini.htm. 
proclaimed in the State Seal of West Virginia over a decade earlier? In the example of the State Seal, Appalachians are helping to create their own stereotype. Second, Diss Debar's Swiss roots and his use of a slogan hailing from the Alps suggest a continuity in mountain cultures that stretches beyond national borders. Another example of this continuity in mountaineer culture and the perpetuation of stereotypes comes from Chechnya. The Chechen Separatist Flag, adopted by rebels fighting for independence from Russia, features the Chechen "lone wolf" that is meant to symbolize the spirit of independence found in the Caucasus Mountains and the violent defiance of Russian domination. Again, we see an official symbol that features imagery that symbolizes stereotypes mountain culture. Once again the message does not originate from an outside source but from within the mountain culture itself. The Russians, who constantly stereotype the Chechens as violent and naturally rebellious, see the flag as giving credence to their views. The Chechens see it as a symbol of pride. ${ }^{115}$

\footnotetext{
${ }^{115}$ Moshe Gammer, The Lone Wolf and the Bear: Three Centuries of Chechen Defiance of Russian Rule (Pittsburgh: University of Pittsburgh Press, 2006), 4-7. It should be noted that the Separatist Flag is not without controversy in the region. Some Chechen Muslims believe it sinful to put an animal on the flag, but the wolf is important because it is a declaration of violent resistance.
} 


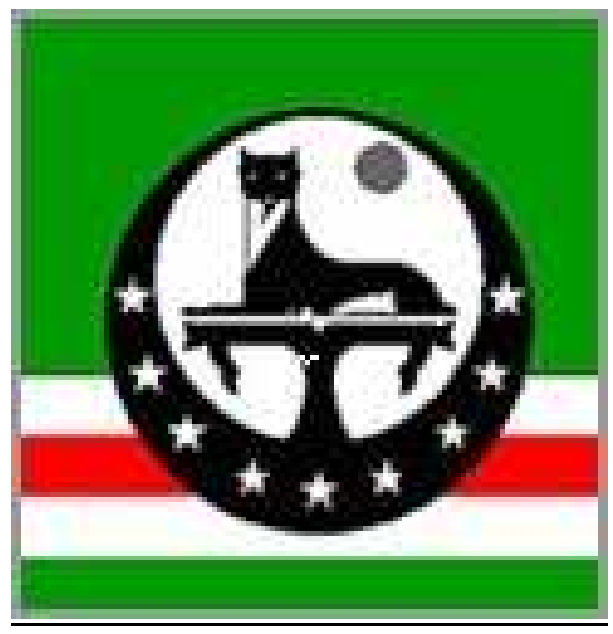

The Chechen Separatist Flag ${ }^{116}$

Official symbols are not the only means by which mountaineers may embellish stereotypes about themselves when it suits them. During the West Virginia Mine Wars, Frank Keeney, then president of the UMWA in West Virginia, testified before a U.S. Senate Investigative Committee on the labor violence in Appalachia. When asked why more mine guards had been killed than mountaineers, Keeney explained, "These miners are crack shots and if they ever shot at a trooper more than twice, he wouldn't be alive. When a real mountaineer of Mingo County shoots twice and don't hit a man, you know he is not shooting at you." 117 The labor leader, and native West Virginian, was more than happy to imply that his strikers were better with guns because of their mountain heritage. Keeney was not afraid to embellish the stereotype of fighting mountaineer.

\footnotetext{
${ }^{116}$ Image found at http://www.axisglobe.com.

${ }^{117}$ Robert Shogan, The Battle of Blair Mountain: The Story of America's Largest Labor Uprising (Boulder, Colorado: Westview Press, 2004), 141-142.
} 
How much of this stereotype is exaggeration and how much is true? Above we have seen that the mountaineers appeared to be just as uncomfortable in their new surroundings during basic training and with the idea of fighting as anyone else. But what about stereotype of the mountaineer and his gun? At least one trainee from Portland, Oregon thought the stereotype held some merit. He said of his training experience: 'Some of the boys were from the hills. They couldn't read or write. You may call them ignorant, but when it came to those guns, they could make us look stupid. They'd take the parts, put 'em in a bag, dump 'em on the floor, and put 'em back together again, blindfolded. Made up their own songs. The verses rhymed and they had a message. It was a real education for me."118

The soldier's comments stand out because he is not trying to use a stereotype. He almost certainly has no hidden agenda. He is not trying to start up a mission program or a settlement school or exploit the natural resources of Appalachia. This soldier was merely making an observation; and it suggests that there may be an element of truth to the stereotype of mountain men and their guns. Other mountaineers were well aware of such observations during basic training and probably always had been. In his study of masculinity in Appalachia W. K. McNeil also feels that mountaineers often embellish stereotypes when it suits them. "Stereotypes generally do not work just one way. Usually there are self-

${ }^{118}$ Terkel, The Good War, 254-255. 
effacing views that are also held by members of the group." ${ }^{119}$ His study further claims, "There is a self awareness of the isolation and harsh conditions of mountain living and the mountain man expresses pride in possessing hardy physical attributes ... resulting from an environment that others find undesirable." ${ }^{, 20}$ While McNeil may be exaggerating the harsh conditions and isolation of mountain life, I believe he is correct concerning the mountaineers' self-awareness of how other perceive them. There are examples of this during the Second World War. When arriving at training camp one mountaineer proudly announced to his drill sergeant that he was, "a fighting son of bitch from West Virginia!"121 While in training, the officers in Earl Richmond's company simply referred to him as "West Virginia." Although Richmond never saw combat on the ground, he took great pride in his ability with a gun while in boot camp. His father had been a sharpshooter who fought on the union side in the Battle of Blair Mountain. Having been taught by his father, Richmond took great pride in being able to outshoot those "city boys."122 William Schnupp gives us an even more striking account:

There was a guy, Norman Shear, in Boot Camp from Shinnston, West Virginia. He had a rifle in his hand from the time he was six years old. [During shooting drills] the colonel said to use his

\footnotetext{
${ }^{119}$ W.K. McNeil, "Mountain Masculinity: Jokes Southern Mountain Men Tell on Themselves." Manly Traditions: Folk Roots of American Masculinities, Simon J. Bronner, ed., (Bloomington and Indianapolis: Indiana University Press, 2005): 261.

${ }^{120}$ Ibid., 262.

${ }^{121}$ Junior L. Scott interview by Elisha Scott, April 19, 2004, Pinch, WV, WVVP.

${ }^{122}$ Earl C. Richmond interview.
} 
windage and elevation to the soldier who said, "I don't use the damn thing." The officer said your outfit will be out here three more days because of this guy refusing the order. Shear said, "Give me a clip." He sat down on the ground. Eight shots went straight through the bulls eye. The whole part was blown out. "You missed one," the Captain said to Norman. He said he was shooting squirrels out of a tree when he was a kid. The reason there were only seven holes and eight bullets was because he put one bullet through the same hole twice. He went eight for eight. He was really dirty. He wouldn't take a bath. One night the guys took him in and gave him a bath because he smelled so bad and they couldn't sleep in the barracks with him. He was down in basic training in Texas. I didn't see him after that. ${ }^{123}$

All of the above evidence gives us a much more complex picture of stereotypes and mountain cultures. On one hand, the experiences of mountaineers in basic training deconstruct some mountaineer stereotypes because they reacted in much the same way as trainees from elsewhere in America. They resisted authority, held on to their individualism, had trouble adjusting to the new environment, and marveled at a country they were seeing for the first time. On the other hand, we see that stereotypes were sometimes selectively embellished by the mountaineers. As they traveled to the camps and their world became much larger, they went from being identified by their local homes to being identified as Appalachians. The fact that all West Virginians, regardless of their local origins, were perceived as the same, they often bonded with one another, defending one another and the culture of their home. Other mountaineers embraced the

${ }^{123}$ William Schnupp interview by Matthew Schnupp, December 15, 2004, Wheeling, WV, WVVP. 
perception of them surrounding their abilities with guns and found an identity by living up to the stereotype. The mountaineers of World War II who did this were not the first to embrace their own stereotypes. As we have seen, Mountain cultures and mountaineers have done so before.

Stereotypes are not always imposed by outside forces, but sometimes are embraced and even, at times, contain an element of truth. Even the Frank Capra films, when stereotyping the Axis countries, used factual information to bolster his claims about their cultures. These facts were manipulated to fit the propaganda, of course, but they were facts nonetheless. ${ }^{124}$ Additionally, the embellishing of their own stereotypes by Appalachians suggests a self-awareness that belies cultural isolation. Comprehending the mainstream American perception of Appalachia, a few mountaineers practiced "self-stereotyping" and tried to live up to the expectations officers and other GIs held of their supposed fighting spirit. If an individual is aware of the stereotypes of his or her culture, he or she must also be familiar with mainstream culture and thus, not so isolated after all. Thus, as they made the transition from local to Appalachian, many mountaineers found a new pride in their own region and culture which probably helped them to retain their individual identities throughout the war. But the identity of the mountaineers would evolve even more before the conflict ended. As he prepared to leave basic training for Europe, Clyde Judy, of Marion County, WV, realized that the world was about to get even larger. "I remember boarding a huge boat to Naples. I was

${ }^{124}$ Dower, War Without Mercy, 15-20. 
just a country boy and this thing was huge. I remember thinking, 'I can't believe something like that floats." ${ }^{125}$ Judy, like thousands of other West Virginians, was about to leave the states for Europe, Africa, Asia, or the South Pacific. Once they were overseas, the mountaineers would no longer be seen as Appalachian, for the people they encountered had no knowledge of Appalachia. Instead, their collective identity would transform from Appalachian to American, and the mountaineers would suddenly be associated with the stereotypes surrounding Americans, as well as the benefits of being called an American.

${ }^{125}$ Clyde Judy interview by Joshua Roscoe and Ryan Wilman, November 9, 2004, Fairmont, WV, WVVP. 
Chapter Three

From Appalachians to Americans

Throughout the course of basic training, West Virginians found themselves clinging to their regional identity with an even greater fervor than they would if they had remained in their hometowns. Mountaineers were no longer identified by their hometown or county, they were identified with West Virginia or Appalachia in general. This tendency to affiliate individuals with a generalized perception of a region also applied to southern boys, western boys, northeastern boys, and everyone else. Thus, the identity of West Virginians transformed from a local one to a broader Appalachian identity. It is not surprising that stereotyping was common between the soldiers as they mingled with others from different regions and ethnic backgrounds. More often than not, the experiences of the soldiers from West Virginia dispel many of the regional stereotypes and reveal a commonality among the soldiers that transcends their cultural and ethnic backgrounds. Nonetheless, some mountaineers embraced these stereotypes and, in the process of "self-stereotyping," helped to legitimize them. But as the young men shipped across the Pacific and Atlantic oceans, their world would grow even larger and their identity would broaden along with their worldview. The Europeans, Africans, Pacific Islanders, and Asians who encountered the mountaineers did not recognize them as such. They only saw the American star on their uniforms and, therefore, 
identified them simply as American. The circumstances overseas diminished the importance of regional identity in favor of a national one. This recalibration of identity not only affected how the mountaineers were perceived and received, but also how they behaved.

This chapter examines West Virginia soldiers overseas who participated in the war outside the theatre of combat. Appalachians found a new social status as they traveled across the globe. For the first time in their lives, mountaineers made more money than the people around them, they were accustomed to greater technological conveniences, they felt more civilized. Perhaps most importantly, mountaineers found themselves free of the stereotypes associated with their regional culture because most of the world's population held no prior knowledge of Appalachia.

First I will examine how the mountaineers reacted to the new social status afforded them because of their position in the American Armed Forces. How they react to their exotic surroundings and heightened position in the social order reveals a great deal about the culture from which they came. Naturally, it is imperative to reveal, as much as possible, the nature of Appalachian culture if we are to deconstruct cultural stereotypes, and find the true nature of this regional culture. Second, I will explore how the mountaineers, alongside other GIs, conducted themselves in foreign lands. Less than fifteen percent of all American 
soldiers actually saw combat in World War II. ${ }^{1}$ While the vast majority of World War II literature on soldiers specifically examines men under combat, very little is written of the non-combat soldier. We can learn much about culture and identity from an examination of the extensive oral and written records left behind of these young men as they travelled around the world and intermingled with nearly every type of culture imaginable.

\section{Shipping Out}

Departing from the east and west coasts, millions of American soldiers boarded vessels and crossed the world's oceans to fight World War II. It was not a pleasant experience. Grace Kennedy, like so many other mountaineers, did not have fond memories of the ordeal. "The ocean voyage, all thirty days of it, was disheartening, to say the least. I thought we'd never reach shore." ${ }^{2}$ There are several reasons for such feelings. The vast majority of the GIs had never been afloat on anything larger than a rowboat. For many, their first voyage coincided with the first time their eyes beheld the ocean. To the average West Virginian, whose largest water experience may have been fishing on the Greenbrier River, the sheer size of the Pacific and Atlantic Oceans must have appeared overwhelming. Most of the voyages lasted a few weeks. As day after day passed

\footnotetext{
${ }^{1}$ Michael C. C. Adams, The Best War Ever: America and World War II (Baltimore: Johns Hopkins University Press, 1994), 96.

${ }^{2}$ Account of Grace Kennedy, World War II Records, WVARHC.
} 
onboard ships with no land in sight, and little to do but think, the psychological effects of drifting further away from home must have hit many GIs very heavily. ${ }^{3}$

In addition, the ships were so overstuffed with soldiers that finding places to sleep was a problem. In a few ships, soldiers slept on the mess hall tables. The crowds made access to a shower or toilet a rare treat. One mountaineer describes the experience:

They had so many kids they had to send overseas you didn't have a place to sleep, see. Everybody slept right on the floor of the ship. If you had to go pee, you had a hell of a time to go out and pee. You had to step over bodies laying all over the damn place. They had no place to put them, see. And, well, I remember the first thing was that they gave you two blankets. Two army blankets, see. And you laid one down and laid on it and cover yourself with the other one. ${ }^{4}$

Soldiers complained about the smell of all the sweaty, dirty bodies cramped into cabins. They were fed twice a day and, in the majority of ships, were forced to eat standing up. The food was worse than in boot camp. ${ }^{5}$ Sea sickness added considerable misery to an already uncomfortable journey. It was common for soldiers to vomit pretty consistently for the entire first week of the voyage. The men typically used their helmets to catch the puke. ${ }^{6}$ Regulations also segregated the men from the women. Armed guards barricaded the separate areas. A few undaunted troops fastened messages to tent pegs and swung them overboard on

\footnotetext{
${ }^{3}$ Norman Longmate, The GIs: The Americans in Britain, 1942-1945 (New York: Charles Scribner's Sons, 1975), 44-46.

${ }^{4}$ John Mangano interview by John Gianola, April 15, 2004, Morgantown, WV, WVVP.

${ }^{5}$ Paul Fussell, The Boys' Crusade: The American Infantry in Northwestern Europe, 1944-1945 (New York: The Modern Library, 2003), 15.

${ }^{6}$ Longmate, The GIs, 46-48.
} 
long lines hoping that they could be read from the ladies' port holes. On such message stated, "I come from Des Moines. I am a Sergeant. Who are you and what do you look like?"7

Once the troops arrived at their various destinations around the world, they again made note of the new lands and landscapes surrounding them. Before the people and culture of a new country made their mark, the landscape, weather, and natural environment was the first to leave a lasting impression on the soldiers. Fred Statts, for example, thought the Scottish highlands displayed, "the prettiest green you ever saw." Another mountaineer was also struck by what he saw in Britain:

I was overwhelmed by the beauty of the British Isles. . . . As we looked at the countryside everyone was taken by its beauty. It was a picturesque scene - the thatched roofs on the homes dotted the hillside and the beautiful green of the grass. At that moment it seemed as though everywhere in the world there should be nothing but peace. It certainly didn't seem to be a locality that was so close to a world of strife and killing. ${ }^{9}$

The passage above gives considerable appreciation than to the scenery and serenity of Britain. Even more striking, however, is how this West Virginian displayed a longing for peace while simultaneously expressing regret over the cataclysmic destruction on the European mainland. It does not sound at all like the

\footnotetext{
${ }^{7}$ Ibid., 50.

${ }^{8}$ Fred R. Statts interview by Margaret C. Schart, February 9, 2002, Pinch, WV, transcript, WVDCH.

${ }^{9}$ Longmate, The GIs, 68.
} 
narrative of a violent, simple-minded, uncivilized man. Perhaps because they came from a rural area known for its scenic beauty, or perhaps because they had never travelled far from home, mountaineers displayed appreciation for the natural world around them everywhere they went. In the Pacific theatre, the tropical environments initially awed troops with the illusion of climatic tranquility in a world at war. Homer Adams wrote, "Anyone with an eye for beauty could not go through the Pacific and not note its splendor.... Some of the islands that we were obliged to remain on for a time were beautiful. In the New Hebrides Islands there were tall, majestic mountains." ${ }^{10}$ Others agreed, at least in the beginning.

Surprisingly, in contrast to a near uniform positive reception for the climate of Britain, West Virginians conveyed negative feelings towards the tropical environment of the Pacific. "Our first glimpse of the Pacific Islands was a beautiful one. Our minds changed when the tropical rains came." ${ }^{11}$ Instead of reveling in the sights of the lovely beaches and sun, tropical rains weighed heavily on everyone's mind on the Pacific Islands. "I'll never forget the New Guinea rain," James Resoncrance recalled, "We got so used to being in the rain that we'd forget whether it was raining or not.", "It always rained," Junior Scott remembered, "Our boots were always wet and that made it real hard to hike miles in a day. Our feet were always blistered."13 John Kaites echoed the point. "I pulled guard duty on Saipan, on the side of a mountain in the rain. Sitting there with a

${ }^{10}$ Account of Homer L. Adams, World War II Records, WVARHC.

${ }^{11}$ Account of James Rasencrance, World War II Records, WVARHC.

${ }^{12}$ Account of John Kaites, World War II Records, WVARHC.

${ }^{13}$ Junior L. Scott interview by Elisha Scott, April 19, 2004, Pinch, WV, WVVP. 
poncho on and rain so hard you couldn't see two feet in front of you. You do what you're told to do." ${ }^{14}$ Another soldier stationed in New Guinea wrote the following, “Once I get home I don't believe I will ever leave America again. Until you have seen it rain in New Guinea, you have never really seen rain. If we had one tenth of this in West Virginia, there would be a major flood." 15 When they were not complaining about the rain they were complaining about the hot weather and the dense jungles. Numerous studies on soldiers during the war note how American soldiers interacted more positively with Europeans than with Asians. Such attitudes are usually attributed to contemporary racial prejudices. ${ }^{16}$

What the above narratives further reveal is that, at least in the case of West Virginians, they reacted more positively to the European climate than the Asian, Pacific, and African climates. No doubt this information would come as a shock to most twenty-first century Americans who view the tropics as home to exotic resorts and tranquil beaches. But in World War II, the soldiers who hopped from island to island did not come as tourists looking for luxury vacations; they came to fight an adversary. Shortly after their various arrivals, the men saw that what appeared to be an inviting climate quickly transformed into an obstacle to

\footnotetext{
${ }^{14}$ Jack Kieffer interview by John Simms, April 24, 2002, St. Albans, WV, World War II Interviews, WVDCH.

${ }^{15}$ John Mueller to Mrs. George Hores, August 5, 1944, Reverend Joseph J. Mueller Collection, Catholic Heritage Center Archives, Wheeling, West Virginia (Hereafter cited as Mueller Collection).

${ }^{16}$ John W. Dower, War Without Mercy: Race, Power, and the Pacific War (New York: Pantheon Books, 1986), 3-14.
} 
overcome. ${ }^{17}$ A final example comes from a chaplain from Wheeling who describes the New Guinea climate:

You have no idea how nice it is to be free of tropic heat and humidity and disease and insects. The moisture penetrates everything. Yesterday I noticed that the beads of my Rosary were disintegrating from moisture ... Almost every campsite was formerly dense jungle and it stands constantly behind you, just waiting a little neglect to engulf everything again ... The soil is black as graphite, rainfall is plentiful, and the sun simply burns down. It can rain in torrents, and before the roads are free of puddles, it begins to get dusty. I have been drenched many times and the same day eaten dust. ${ }^{18}$

There is another important element to the early reactions of West Virginia soldiers when they arrived overseas, particularly in the Pacific, Asia, and Africa. Upon completion of his basic training, Forbes Blair wrote, "The next thing I knew, I was in a transport, heading for some remote spot in the Pacific." ${ }^{19}$ The key word in the sentence is "remote." On the one hand, it implied that Blair knew how far away from home he was about to be, but on the other hand, it implied isolation. As stated before, the soldier narratives of West Virginians in World War II give us a clearer portrait of Appalachian culture and help us to better understand the validity, or lack thereof, of the popular theories of inherited cultural traits that heavily influenced government policies of the belligerents and helped to justify their fight in the Second World War. A key component of the stereotypical Appalachian is that he was culturally backward and violent in part because of over

\footnotetext{
${ }^{17}$ Patrick Gainer to his wife, June 15, 1945, Patrick War Gainer Collection, WVARHC.

${ }^{18}$ John Mueller to Mrs. George Hores, May 12, 1943, Mueller Collection.

${ }^{19}$ Account of Forbes Blair, World War II Records, WVARHC.
} 
a century of isolation in the mountains. By staying hidden away in isolation from the rest of American society, hillbilly families bred a homogenous population that preserved an American frontier fighting spirit and also left them lacking in cultural modernity. ${ }^{20}$ This viewpoint was given credibility by contemporary scholars, often partially influenced by Social Darwinism and the theory of Eugenics, and it fit right in line with the school of thought that portrayed the Japanese as inherently treacherous and African-Americans as inferior to white Americans. ${ }^{21}$ All of the theories based on inherent cultural traits, whether discussing an American redneck, or an interned Japanese-American, or even an east European Jew, were all different fruits picked from the same intellectual tree. ${ }^{22}$ Granted, some groups were more stereotyped than others, and certainly persecution was by no means spread evenly during the Second World War. But a close examination of the Appalachian stereotype alongside soldier narratives during the war puts a significant dent in the ideological armor that justified mistreating and even killing groups of people just because of an "assumed otherness" as promoted by the media, government propaganda, and scholarly writings all around the world.

\footnotetext{
${ }^{20}$ Ronald L. Lewis, "Beyond Isolation and Homogeneity: Diversity and the History of Appalachia," Back Talk from Appalachia: Confronting Stereotypes, Dwight Billings and Kathleen Blee, eds., (Lexington: University of Kentucky Press, 1999), 21-46.

${ }^{21}$ Stevan Kuhl, The Nazi Connection: Eugenics, American Racism, and German National Socialism (Oxford and New York: Oxford University Press, 1994), 1-8.

${ }^{22}$ For more on the intellectual roots and evolution of these theories as it was applied to various cultures and nations, see Dower, War Without Mercy, 3-15; Heather Pringle, The Master Plan: Himmler's Scholars and the Holocaust (New York: Hyperion, 2007), 27-35; John Alexander Williams, Appalachia: A History (Chapel Hill, University of North Carolina Press, 2002), 194212.
} 
In this case it is the isolation of the mountaineers that comes to the forefront. The West Virginia narratives of World War II show how the soldiers felt isolation because of where they went, not where they came from. Patrick Ward Gainer wrote to his wife, "It is cool on the island, but the night is beautiful. It looks pretty out over the blue ocean. Even the piles of rock look pretty. If you could be with me we could be happy. It is so strange out here so far - on a little island so far from anywhere." ${ }^{23}$ At times, the sheer distance from home made them feel isolated. James Weekley was stationed in the Philippines. He stood out on the dock after dark and wrote, "When I see a pretty moon out at night, it's noon back home. ${ }^{24}$ Driving the point further is the observation of John Kaites, who did not feel far from civilization in West Virginia, he felt far from it where he served. "I didn't expect to be stationed in New Guinea for two straight long years. Matter of fact, to spend one year in an uncivilized place was quite a headache to anyone." 25 In the eyes of the mountaineers, the places overseas were places of isolation and lacking in modernity - not their homes. The following passage from the Reverend John Mueller puts it in even more detail:

My work is going on well enough. The great difficulty in antiaircraft is the constant waiting, waiting, waiting! Of course, my work is pretty much the same, no matter in which branch I may be placed ... This life is really pretty trying. Cut off from almost all the normal associations of a lifetime, one is apt to get a distorted idea of a lot of things. It would be nice just to see a person once again, dressed in American clothes.

\footnotetext{
${ }^{23}$ Patrick Gainer to his wife, August 19, 1945, Patrick War Gainer Collection, WVARHC.

${ }^{24}$ James Weekley interview by Franchesca Nestor and Matthew Gotkowski, November 25, 2004, Bridgeport, WV, WV Veteran's Project, WVARHC.

${ }^{25}$ Account of John Kaites.
} 
And as for all the nice hotels, restaurants, theatres, roads, and homes (and furniture!), well, we just dream of these things. Bathrooms and toilets that flush, and easy chairs, and good food almost seem like unreal fancies of the imagination. The Army pays us well, but let me tell you, there is no compensation adequate. ${ }^{26}$

As we shall see, the soldiers' near universal belief that they were the ones treading on uncivilized ground not only tainted their letters and recollections, it would impact their interactions with other cultures and their racial attitudes.

\section{Race and Culture}

Hermann Goring was among the first to refer to the Second World War as the "great racial war." It is common knowledge among historians that the racism of Hitler's Germany and Tojo's Japan were fundamental to their policymaking decisions. ${ }^{27}$ It is also well established by scholars that the Allies used racial and ethnic theories and stereotypes to bolster their own policies at home and justify imperial conquests abroad. In short, race was on everyone's mind, from the generals to civilians. Louise Caruso, an Italian-American from Morgantown, had ethnicity on her mind when her brothers went off to war to possibly fight against other Italians. "I had one concern," she said, "and that was I can remember as a young teenager wondering if my brothers would ever be in a war situation where

\footnotetext{
${ }^{26}$ John Mueller to Mrs. George Hores, May 12, 1943, Mueller Collection.

${ }^{27}$ Niall Ferguson, The War of the World, xlii.
} 
they may have to kill a relative. We did, at that time, have cousins who were still in Italy. And that was a concern of mine, and I think it was a concern of theirs as well. The truth of the matter is they didn't serve where that would have been a problem." ${ }^{28}$ With such concerns on ethnicity and race so prevalent, how did they reflect in the soldier narratives of West Virginians? Despite theories of cultural isolation, Appalachians did not exist in an ideological vacuum. As the mountaineers hopped from island to island in the Pacific, or from village to town in Europe, to what extent did they reflect the mainstream racial and cultural views of their own country? As common victims of stereotyping, it may be reasonable to assume that Appalachians themselves would be more wary of stereotyping others. The evidence suggests that this was not necessarily the case. However, before we can delve into the racial and cultural reactions of soldiers as they encountered various groups overseas, we must first look at contemporary viewpoints of race and culture in the United States and to what extent Appalachians adopted the belief system of the majority.

The United States was the most ethnically diverse of all the belligerents during the war. Because of this profound diversity, the United States government, media, and military spewed forth a nationalistic propaganda based on ideals rather than race or ethnicity. This is especially evident in the famous Frank Capra Why We Fight films. Capra depicts the United States as bound together by its constitutional values of toleration and a "rags to riches" mentality while the Axis

\footnotetext{
${ }^{28}$ Louise Caruso interview by Leslie Saunders, April 4, 2006, Morgantown, WV, WVVP.
} 
powers based their actions on racial supremacy. ${ }^{29}$ While the United States did and still does try to promote a society of ideals over a society of race, any nation-state with such a diverse population living in close proximity will experience tension and discrimination between groups. The ideal of racial toleration may have been touted in propaganda but it was far from reality. Japanese and Italian internment served as clear examples. The Axis Powers quickly pointed out American racial hypocrisy and declared that Lebensraum and the Greater East Asia Co-Prosperity Sphere was no different than the U.S. government's conquest and displacement of Native Americans in the late $1800 \mathrm{~s}^{30}$

The most obvious barometer of racial conflict within the United States was, of course, the social status and discrimination facing African-Americans. Even though the war brought extraordinary changes to African-Americans, racism remained a staple of American life. An enormous migration of blacks from the rural south to the urban north led to huge increases in employment throughout the war, but also created more conflict, such as in the Detroit Race Riots in 1942. A. Philip Randolph's March on Washington Movement made minor progress in getting equal treatment in the workforce and blacks showed their patriotism by joining the military at a rate sixty percent higher than their proportion of the population. ${ }^{31}$ Unfortunately, the patriotism they displayed in their willingness to

\footnotetext{
${ }^{29}$ Eric Smoodin, Regarding Frank Capra: Audience, Celebrity, and American Film Studies, 1930-1960 (Durham: Duke University Press, 2004), 160-170.

${ }^{30}$ Dower, War Without Mercy, 147-154.

${ }^{31}$ William Chafe, The Unfinished Journey: America Since World War II (Oxford: Oxford University Press, 2003), 17-18.
} 
serve as soldiers was not well received within the U.S. Armed Forces. Black soldiers worked in military mess halls or on supply lines and were kept away from combat whenever possible. Publications such as Newsweek and The New Republic justified the placement of African-Americans away from the battlefield by claiming that blacks lacked the discipline and mental toughness to fight a modern war. ${ }^{32}$ Civil Rights groups had to put tremendous pressure on Washington in order to ensure that groups such as the Buffalo Soldiers and the Tuskegee Airmen were deployed and could see action. ${ }^{33}$ Not only did officers enforce strict segregation within the ranks, but the Red Cross even kept stores of African-American blood plasma separate from Caucasian blood, lest a white man be contaminated with the wrong blood type.$^{34}$ Clearly, attitudes of racism persisted strongly in America during the war.

To what extent, then, did mountaineers reflect this racism? There is some evidence suggesting that white Appalachians may have been historically less racist than the rest of America. West Virginia, for example, was a child of the Civil War, born out of a refusal to secede along with Virginia. West Virginia's secession from Virginia helped give the state a reputation as being unionist and abolitionist. Some advocates for creating the new state, such as Henry Ruffner and Alexander Campbell, were also outspoken abolitionists. Adding to the idea (whether deserved or not) of an abolitionist West Virginia was the sensational 1859 raid led by John

\footnotetext{
${ }^{32}$ Donald L. Miller, The Story of World War II (New York: Simon \& Schuster, 2001), 250.

${ }^{33}$ Ibid., 247, 475-477.

${ }^{34}$ Chafe, The Unfinished Journey, 19
} 
Brown at Harpers Ferry. ${ }^{35}$ In the years after the Civil War many black civil rights leaders emerged from West Virginia. Among them were Booker T. Washington, Memphis Tennessee Garrison, and Minnie Buckingham Harper, the first AfricanAmerican woman to serve as a member of a legislative body in the United States. ${ }^{36}$ Throughout the industrial period, most African-Americans in Appalachia were found in the coalfields, where some degree of class unity existed between black and white miners. Because the coal towns were not segregated as much as the rest of society, black and white miners in places such as northern Alabama and West Virginia found that their working and living conditions left them with quite a lot in common. ${ }^{37}$ In fact, the United Mine Workers of America was the first of the big industrial unions to try to organize blacks. Such evidence has led some historians to suggest that class became more important than race in the union struggles of the Appalachian coalfields. Blacks and whites worked together, went on strike together, and fought mine guards together. ${ }^{38}$ Furthering the idea of a "more

\footnotetext{
${ }^{35}$ C. Belmont Keeney, “Abolitionism," The West Virginia Encyclopedia, Ken Sullivan, ed., (Charleston: West Virginia Humanities Council, 2006): 1. This is not to say that slavery and racism did not exist in Appalachia. Slaves were a large part of the salt industry in the Kanawha Valley and in the tobacco plantations of the eastern panhandle of West Virginia. Additionally, some historians have argued that some parts of Appalachia were just as supportive of slavery as their lowland southern neighbors. See John C. Inscoe, Mountain Masters: Slavery and the Sectional Crisis in Western North Carolina (Knoxville: University of Tennessee Press, 1989) and John Stealey, The Antebellum Kanawha Salt Industry and Western Markets (Lexington: University of Kentucky Press, 1993).

${ }^{36}$ Williams, Appalachia, 182-184.

${ }^{37}$ Edwin L. Brown and Colin J. David, eds., It is Union and Liberty: Alabama Coal Miners and the UMW (Tuscaloosa and London: The University of Alabama Press, 1999), 4-6.

${ }^{38}$ See David Allan Corbin, Life, Work, and Rebellion in the Coalfields (Urbana: University of Illinois Press, 1981); Ronald L. Lewis, Black Coal Miners in America: Race, Class, and Community Conflict, 1780-1980 (Lexington: University Press of Kentucky, 1987); Joe William Trotter Jr., "Black Migration to Southern West Virginia," Transnational West Virginia: Ethnic
} 
tolerant" Appalachia was the fact that, at the outbreak of World War II, West Virginia boasted three African-American colleges: Storer College, West Virginia State, and Bluefield State. West Virginia State College, an elite African-American school, became the first institution to train blacks to be officers in the military. ${ }^{39}$

African-Americans in West Virginia played an active role in supporting the war effort. Immediately after Pearl Harbor, Delegate Fleming A. Jones, from McDowell County and the only African-American in the state legislature, sponsored an act to create the Negro National Guard Unit in West Virginia. The act was quickly passed and $\$ 18,000$ in funds was made available, allowing African-Americans to, "share in the military establishment and responsibility of the state. ${ }^{40}$ Hundreds of blacks immediately volunteered to join. ${ }^{41}$ The same month Daniel W. Ambrose, an African-American attorney from Huntington was named the Civilian Defense Coordinator in Charge of Negro Activities and was given an office at the capitol. Ambrose spent the duration of the war working with the Office of Civilian Defense and its involvement in black communities. ${ }^{42}$ While numerous blacks left the state to serve in the military, many more left to take

Communities and Economic Change, 1840-1940, Ronald L. Lewis and Ken Fones-Wolf eds., (Morgantown: West Virginia University Press, 2002), 137-153.

${ }^{39}$ Louis E. Keefer, Scholars in Foxholes: The Story of the Armored Specialized Training Program in World War II (Jefferson, North Carolina: McFarland and Company, 1988), 1-8.

${ }^{40}$ McDowell Times, January 24, 1942.

${ }^{41}$ Ibid.

${ }^{42}$ Charleston Gazette, January 20, 1942. 
available jobs in the large industrial cities of the northeast. The African-American population in West Virginia declined significantly after the war began. ${ }^{43}$

But all of these historical facts, from the birth of West Virginia as a state to the Second World War, really only skim the surface of race relations in the Mountain State. In many Appalachian communities, tensions between blacks and whites were the same as in much of the rest of the country. Georgia Chapelle, despite having two brothers who served during the war, still faced considerable discrimination at home. "I was born over in Westover [WV] and we had to walk from Westover to White Avenue [on the way to school], which is in Greenmont, and kids would call you names, stone you, the whole nine yards. It got so bad that my mother used to have to come and walk to meet my sister and I because the kids in the neighborhood called you names and threw stones." ${ }^{\circ 4}$ In most towns, laws enforced strict segregation between blacks and whites, even in some coal towns. The company town that Karen Owens grew up in African-Americans lived in a section called Black Bottom. According to Mrs. Owens, "There was no interaction at all [between blacks and whites]. I was scared to death of 'em. I went to work at a supermarket and a black person touched me, and I rubbed my hand because, it was like I tried to rub it off. You know I didn't, I had never been around a black person to touch." 45

\footnotetext{
${ }^{43}$ Connie Rice, Our Monongalia: A History of African-Americans in Monongalia County (Terra Alta: Headline Books, Inc., 1999), 112,144.

${ }^{44}$ Georgia Sullivan Chapelle interview by Jeff Tidd, May 2004, Westover, WV, WVVP.

${ }^{45}$ Karen Owens interview by Lauren Kress, April 26, 2006, Waynesburg, PA, WVVP.
} 
If such racial prejudice and relative ignorance remained at home it is unsurprising that similar feelings existed towards other races among the troops who went overseas. On the home front, it was common for civilians to think of the Japanese as subhuman, particularly when the media reported stories of the Japanese treatment of American POWs. Dorothy Lucas, from Inwood, held harsh feelings over the torture of American troops. "We didn't do our prisoners of war like that," she said, "because we're not like that. We're not like that. But they [the Japanese] were savages. They were savages. That's what they were. ${ }^{, 46}$ Direct interaction did not necessarily change racial feelings. In a letter to a friend, J. Bertsel Coonts wrote, "I have to say this about the little brown imps, they are the dirtiest and crudest of any race of men that I have ever met!" ${ }^{\prime 47}$ Military studies during the war indicated that soldiers felt a stronger hatred towards the Japanese than the Germans. In a military survey conducted in 1944, sixty-five percent of U.S. soldiers in Europe in answering the question, "What do to with the Axis Powers after the war?" believed that the Nazi leaders should be punished while $24 \%$ said to wipe out the whole nation. For the Japanese, $47 \%$ agreed to punish only the leaders while forty-two percents said to wipe out the whole nation. The same survey also reported that eight-six percent of American troops in Asia held a favorable view of the Chinese and seventy-eight percent liked the British people. ${ }^{48}$

\footnotetext{
${ }^{46}$ Dorothy Lucas Interview by Angela Sirna, March 30, 2006, Inwood, WV, WVVP.

${ }^{47}$ J. Bertsel Coonts to Harris A. Jones, October 18, 1945, WV War History Commission Records, WVARHC.

${ }^{48}$ What the Soldier Thinks: A Monthly Digest of War Department Studies on the Attitudes of American Troops, Number 2, January 1944, 8-15, Lawrence Nuce Collection, WVARHC.
} 
The survey indicates that while troops hated the Japanese more than the Germans, they held favorable views towards both the Chinese and the British. This may lead one to conclude that which side a different race fought on heavily affected racial attitudes. But surveys and statistics can be misleading. A few troops still looked down on the diverse races and cultures they found elsewhere. David Kessler wrote, "China was the Hell hole of the Far East." ${ }^{49}$ When Duane Uldrich arrived in Casablanca, he was "met by a horde of dirty Arab children instead of Bogart." ${ }^{, 50}$ Michael Babinetz said something similar, connecting the climate with the people. "Casablanca left me with an impression of filth and almost unbearable heat." ${ }^{51}$ At times, soldier accounts were merely condescending. Homer Adams spent time in the New Hebrides Islands. Of the people there, he said, "The natives were always a source of fun and curiosity.",52

Not everyone felt prejudice towards other races. Like the motivations for men to join the military in the war, soldiers from West Virginia held a variety of views concerning different groups. George Kovach felt that working in the coal mines made him more accepting to diversity when he went into the military. "People tolerated everybody because there were a lot of foreign elements in the coal mines.... We were all Americans whether we were Hungarian, Polish,

\footnotetext{
${ }^{49}$ Account of Daniel Kessler, World War II Records, WVARHC.

${ }^{50}$ Account of Duane Uldrich, World War II Records, WVARHC.

${ }^{51}$ Account of Michael Babinetz, World War II Records, WVARHC.

${ }^{52}$ Account of Homer L. Adams.
} 
Black, or what have you, and Americans had a great deal of patriotism." ${ }^{, 53}$ Paul Adkins held a high opinion of the Filipino people. "These Filopinos [sp.] are really the most polite and hospitable people I have ever seen. They treat us like kings." 54 Coming from a region with a low economic status like West Virginia may have impacted the opinions of mountaineers when they encountered the impoverished victims of war. While in Guam, Albert Taylor found an indigenous family living under an old, abandoned house and felt sympathy for them. Against orders, he took food and supplies off his ship to give them and would play "hillbilly songs" for them. One day he shot a water buffalo for them to eat and helped them cook it. "It was pitiful to see how some of them people was mistreated and lived," he said. ${ }^{55}$ Lonnie Benson, who saw combat in the Pacific, did not let the feelings of battle spill over into personal hatred for the Japanese. He said, "I had nothing against the Japanese personally. They were good fighters and they were just like us, fighting for their country." ${ }^{, 56}$ Another mountaineer, Sylvester Gaspersich, also felt sympathy towards the Japanese. "Towards the end of the war, I traveled in a plane that also kept, I think, five or six Japanese prisoners. And when I looked at them I thought there is an ordinary working man, brought into the service to do the will of a professional and I felt a little bit sorry for them. I just shook my head.

\footnotetext{
${ }^{53}$ George Kovach interview by Matthew Chambers, December 3, 2004, Morgantown, WV, WVVP.

${ }^{54}$ Paul Atkins to his mother, November 7, 1944.

${ }_{55}$ Albert Taylor interview.

${ }^{56}$ Don Benson and Lonnie Benson interview by Jeff Maddox, November 18, 2004, Morgantown, WV, WVVP.
} 
Just a common worker doing what some smart aleck told them to do. ${ }^{.57}$ In accordance with what some labor historians have written about coal mines in West Virginia, Gaspersich's comments reflect more of a class worldview than a racial worldview.

Gaspersich was not the only one to change his opinion. After the Japanese surrender, troops who occupied the Japanese mainland were shocked to find civilians bowing to them and treating them with great respect. The Japanese civilians often gave American troops presents, entertained them, and expressed contempt for the militaristic leaders who had lead their country to disaster. ${ }^{58}$ The Reverend John J. Mueller, of Wheeling, spent a few months stationed in Yokohama, Japan. Of the Japanese, he observed, "It is an interesting phase of things that we are now in, and so peaceful and trouble-free that we are still amazed. The Jap is simply unpredictable. He has completely about-faced in his attitude, so now we are even welcome in many homes." ${ }^{, 59}$ Mueller's opinion of the Japanese does not appear filled with racial hatred at all. Whether or not this is because of Mueller's religious beliefs or because the Japanese, by this time were defeated, or because the racial caricatures of wartime propaganda proved to be different than the reality is uncertain. It is probably safe to say that a combination of these factors contributed to his and the other viewpoints mentioned above.

\footnotetext{
${ }^{57}$ Sylvester Emil Gaspersich interview by John Tyler Slavey and Patrick Mullett, November 23, 2004, Princeton, WV, WVVP.

${ }^{58}$ John W. Dower, Embracing Defeat: Japan in the Wake of World War II (New York: The New Press, 1999), 24-25.

${ }^{59}$ John Mueller to Mrs. George Hores, October 22, 1945 Mueller Collection.
} 
Nonetheless, he did write complimentary things about the Japanese, "I have met some lovely Japanese people, cultured, refined, and well educated." 60

Nevertheless, a preconceived racism is evident in what he wrote. The narrative expresses surprise that he would find "cultured, refined, and well educated" Japanese. Although Mueller's cultural observations were generous by contemporary standards, he still, like many American military personnel, had sanitary concerns and felt that he was in a less civilized place. "In America, one goes out to the country for fresh air. But that is not the case so much here. There is beauty for the eyes, but not for the nose, for human fertilizer is everywhere used and WOW! That is why we are rigorously warned not to eat green vegetables of any sort in Japan. For worms are a common malady."

And sympathy was not merely reserved for defeated troops and displaced civilians in Asia and the Pacific. Fred Statts wrote of one interesting incident while guarding German prisoners after the Battle of Saint Malo. "This one kid had a watch on him and it was a beautiful thing. I'd never seen one like it then. It had a date and time and all. I took it away from him and he went to crying. And I went to messing around with it awhile and he got to bawling, so I gave it back to him. ${ }^{, 62}$ West Virginians then, the vast majority of whom were Caucasian, came from a society where racism was open and accepted in everyday life, and yet their reactions to other races were a mixed bag. A percentage of them continued to feel

\footnotetext{
${ }^{60}$ Ibid.

${ }^{61}$ Ibid.

${ }^{62}$ Fred R. Statts interview by Margaret Scharf, February 9, 2002, Pinch, WV, World War II Interviews and Papers, WVDCH.
} 
prejudice towards the various cultures and races they encountered during the war while others expressed sympathy and a measure of respect for others.

A number of factors, from wartime experience to combat and to interaction with other cultures, influenced how troops felt about the different ethnic groups around the world. It would be inaccurate to say that white mountaineers were all racist, but it would be just as inaccurate to argue that they were all tolerant of diversity. In all, one can only conclude that racial attitudes varied from person to person. In this sense, the degree of racism was an individual decision, shaped by individuality. The presence of such individuality, or conversely, the lack of unanimity, among the mountaineers once more strikes yet another blow against the stereotyping of groups. As the war continued and the mountaineers better acclimated themselves to their surroundings, they found themselves in yet another entirely new situation - one of economic supremacy over the surrounding peoples.

\section{Appalachians as Wealthy Americans}

In his famous work, The Great War and Modern Memory, Paul Fussell wrote, "Every war is ironic because every war is worse than expected." ${ }^{\text {63 }}$ The ironies of World War II are almost too numerous to count. Among them is the irony that many United States soldiers were not treated as true Americans until

\footnotetext{
${ }^{63}$ Paul Fussell, The Great War and Modern Memory (Oxford: Oxford University Press, 1975),
} 28. 
they left America. Amazingly, societies such as Germany and Japan, who had been influenced by their own country's propaganda to judge others based on ethnicity and race made no, or few, racial or cultural distinctions among the American GIs when they entered their country as conquerors. Back home, groups such as African-Americans, Italian-Americans, and Appalachian hillbillies were still stereotyped by the mainstream media, academia, and the populace. In Europe and Asia, they could be seen as true Americans. Take, for example, the testimony of an African-American soldier as he took part in the liberation of a concentration camp in Germany.

I think the only man ever to call me an American, and say it like I was as good as any American he was likely to find, was a little Jewish man. ... I am ashamed to say I was afraid to touch him, but he hugged me like nobody ever hugged me in my life. ${ }^{64}$

Other African-Americans had similar experiences. In Britain, segregation was not enforced, and the locals were even offended at the treatment that white Americans gave to blacks. A few violent incidents occurred in Bristol and Cheltenham, during which several were injured, all because the British refused to comply with American segregation. ${ }^{65}$ British women were even accepting of black men. One African-American from West Virginia remembered:

\footnotetext{
${ }^{64}$ Christopher Paul Moore, Fighting For America: Black Soldiers - The Unsung Heroes of World War II (New York: One World Books, 2005), XVII.

${ }^{65}$ Fussell, The Boys' Crusade, 21-22.
} 
Most European whites accepted us real well. It wasn't like in the United States. There was white women in bars or clubs that were open to relations that weren't okay back home. And many of the European white men over there, they were okay with all of that. They didn't oppose to any relations with white women. We wondered why whites over there accepted us so much, see as how we were occupying their country and whites back home didn't accept us. Lots of blacks wanted to stay in Europe even after the war because they felt like they were welcome there. A lot of them felt like strangers in the United States after that. ${ }^{66}$

Writing about his wartime experiences over a year later, Rudy Barie found those same conditions worthy of mentioning: "One thing we noticed in our short stay there was the lack of racial distinction. It was a common sight to see an English girl walking arm in arm with a Negro. ${ }^{, 67}$ If African-Americans were treated as simply "American," how much more so for white Appalachians? Americans, whether northern, southern, white or black, were all simply "Yanks" to the British. ${ }^{68}$ Adding to the irony of being treated "more American" outside of America, was the heightened economic status that Appalachians enjoyed once they left the country. An American private was paid \$13.84 a week while the British private was paid $\$ 2.82$. An American lieutenant made over forty dollars a week while his British equivalent made less than twenty. ${ }^{69}$ The American soldiers also were healthier and subsisted on a better diet than all the other belligerents in

\footnotetext{
${ }^{66}$ Dennis Gildon interview by Joshua Cutwright, April 4, 2004, Morgantown, WV, WVVP.

${ }^{67}$ Account of Rudy Blair, World War II Records, WVARCH.

${ }^{68}$ Longmate, The GIs, 69-80.

${ }^{69}$ Fussell, The Boys' Crusade, 17.
} 
the war, consuming between 3,000 and 3,500 calories a day. Such a disparity in wealth, supplies, and food disheartened the Axis soldiers. German POWs lost confidence that Germany could win the war as they witnessed the good health and massive supply lines of U.S. troops. ${ }^{70}$ The overall wealth and technological advancement of the United States had a similar impact on Japanese prisoners. One said, "We were shocked when the Americans built an airstrip overnight. We had never seen bulldozers before. Then we saw all their warships. 'Japan is lost,' I thought to myself for the first time." ${ }^{, 71}$ The impression of advanced technology and wealth carried over to the general impression of individual American troops. Thus, as the collective identity of West Virginia soldiers transitioned from Appalachian to American, they found themselves, for the first time near the top of the economic food chain. The mountaineers were quick to notice the difference. One mountaineer, for example, referred to Australia as "fairly civilized," but commented that the fanciest hotels in Australia are at best "like our middle class hotels." ${ }^{, 72}$ Harry Slaughter's recollection offers an even more revealing narrative:

In England they were superb. English people realized we had actually saved them. I became acquainted with a lot of the British people. In fact, there was a fellow that lived in Redding, England who was an aeronautical engineer in the spitfire factory. ... I had the pleasure of going to his home. To give you a comparison of how people lived, most of the people in England did not have an inside toilet. He did. But he made the equivalent of about forty dollars a week as an engineer.

\footnotetext{
${ }^{70}$ Lee Kennett, G.I.: The American Soldier in World War II (Norman: University of Oklahoma Press, 1997), 96.

${ }^{71}$ Haruko Taya Cook and Theodore F. Cook, eds., Japan at War: An Oral History (New York: The New Press, 1992), 280.

72 John Mueller to Mrs. George Hores, August 5, 1944, Mueller Collection.
} 
We were allowed to draw rations from the mess hall if we went to a British home because their food was rationed and we didn't want to jeopardize their welfare. One of the funny things I remember, I took a can of whole kernel corn. At the time, the British didn't eat whole kernel corn and they thought that was for horses. But I showed them how my mother cooked it and they thought it was wonderful. Another thing that they thought was great was canned corned beef. They didn't get much of that. The main food was fish and chips, and they only opened [restaurants] at certain times and when you got it, it was wrapped in a newspaper. ${ }^{73}$

There are several distinguishing features from this passage. First, Slaughter noted how the British (or at least the ones he encountered) welcomed him and treated him with respect. Slaughter had come from a region in America where his fellow countrymen often did not respect him. Second, to turn another Appalachian stereotype on its head, Slaughter points out that most of the British did not have inside toilets. For many years, the outhouse has been seen as evidence, even a symbol, of Appalachian poverty and lack of modernity. ${ }^{74}$ In this case, an Appalachian mentions outdoor toilets as evidence of British poverty. Third, Slaughter's comments reveal the variety of food that he was accustomed to verses the lack of variety that the war weary British enjoyed. It cannot be overlooked that, at the beginning of World War II, Great Britain oversaw the largest empire in world history and yet, an Appalachian "hillbilly" coming from one of the most poverty-stricken and malnourished regions of America enjoyed a higher standard

\footnotetext{
${ }^{73}$ Harry Slaughter interview.

${ }^{74}$ For reference to the outhouse as a popular image of Appalachian stereotypes, see Billings, Norman, and Ledford, Back Talk From Appalachia, 4-6.
} 
of living and even brought food to an Englishman who was, by British standards, far above the poverty line. The same West Virginian remains consistent in his portrayal of the French:

My general impression about the French people were that they were a grateful people. They were actually prisoners of the Germans. I got to know a fellow, we called him Charlie, he was able to speak enough English that we could hold a conversation with him. He ran a restaurant and bar. He had some horses. When we would go down there and he would fix us a steak, I would kid him that it was a horse steak. I used to say, "Which one of those horses are we eating today?" He used to get upset with me and say, "You no eat my horses!" Of course it was horse meat. It wasn't bad at all. ${ }^{75}$

Once again we see that at least one West Virginian felt welcomed in a foreign land. Whether Slaughter and his fellow troops were well-received because they had liberated the French from the Germans, or because they had money to spend, or both is a matter of debate. Another influencing factor for the reception that American troops received is that Hollywood films and American music had given Europeans an affinity for American culture. ${ }^{76}$ Nevertheless, the image persists of Americans spending money in restaurants and bars while the locals scrape to make ends meet. It is also worth noting that, having experienced or at least seen desperate economic times during the depression, Slaughter himself did not feel that eating the horsemeat served to him in France was beneath him.

\footnotetext{
${ }^{75}$ Harry Slaughter interview.

${ }^{76}$ Kennett, G.I., 119.
} 
For many contemporary Americans, widespread poverty, starvation, and homelessness are sometimes forgotten casualties of World War II. This study has already noted how some mountaineers found hungry and desperate civilians in the Pacific Theatre. Even in the west, conditions were appalling. American troops everywhere could not help but to be profoundly impacted by the poverty they found as a result of the war. William Schnupp recollects a grim scene outside U.S. mess halls: "At meal times children and old women lined up outside our dining room with their plates and pans. They collected the scraps off our mess kits as we came out from our meal." ${ }^{, 77}$ It was common for American soldiers to spread goodwill by sharing food with civilians in occupied territories. Children in both Europe and Asia were drawn to American soldiers because they gave out chewing gum and chocolate bars. ${ }^{78}$ Some soldiers used their stocks of chocolate and cigarettes to their advantage. "I became a rich man when I was in the hospital in Paris." William Schnupp said. "When we were in the field we got lots of rations of cigarettes. We still got them while I was in the hospital. I had so many cigs I didn't know what to do with them. . . I sold them for twenty dollars a carton.,"79 American troops were not always beloved. Nearly everywhere they went, civilians and other troops remarked upon the brashness, cockiness, and outspoken nature of Americans. ${ }^{80}$ If American films served as a "goodwill ambassador" to

\footnotetext{
${ }^{77}$ Account of William H. Godfrey, World War II Records, WVARHC.

${ }^{78}$ Kennett, G.I., 119-120.

${ }^{79}$ William Schnupp interview by Matthew Schnupp, December 15, 2004, Wheeling, WV, WVVP, WVARHC.

${ }^{80}$ Kennett, G.I., 122.
} 
many Europeans, they also gave them the impression of Americans as cowboys.

One West Virginian, while serving in Italy, wrote home that the locals would yell out, "Hi, Ho, Silver!” as Americans drove or marched along the streets. ${ }^{81}$ Citizens from Germany to Australia expected Americans to be friendly and personable, but also loud, lacking in manners, disrespectful of more "ancient" cultures, irreverent, and braggarts. ${ }^{82}$ One British soldier said, "They are so friendly that they become contemptuous, you know." ${ }^{83}$ A good example of how Americans mixed their sense of humor with their brashness comes from Australia, where military engineers built an airstrip and named it Lacka Nookie, assuring locals that it was a revered ancient Indian name. ${ }^{84}$ At least one West Virginian displayed some self-awareness of this behavior. "A lot of the British soldiers did not like Americans," he wrote, "We were uncouth." 85 Another prime example comes from John Mangano, who told a story about maneuvers in Britain:

They had so many things that were hundreds and hundreds of years old, you know. We had tanks and we went across a little creek, just a little stream of water, and we crossed it and the tanks had to cross back on a bridge. When the tank got turned around, the ass-end of the tank hit that bridge and knocked that damned bridge down. Oh, people just raised hell. "That's three hundred years old," they said. And this buddy of mine, he says, "My God, if its three hundred years old, it's

\footnotetext{
${ }^{81}$ Walter Powell to his parents, October 13, 1944, West Virginia War History Commission Records, WVARHC.

${ }^{82}$ Petra Goedde, GIs and Germans: Culture, Gender, and Foreign Relations, 1945-1949 (New Haven: Yale University Press, 2003), 2, 32-34.

${ }^{83}$ Philip Ziegler, Soldiers: Fighting Men's Lives, 1901-2001 (New York: Alfred A. Knopf, 2002), 227.

${ }^{84}$ Kennett, G.I., 123.

${ }^{85}$ Harry Slaughter interview by Brett Wooten, April 29, 2002, Winfield, WV, World War II Interviews and Papers, WVDCH.
} 
time to be replaced!" [laughs] He just knocked the hell out of it. ${ }^{86}$

Another facet of how the Americans' helped to fulfill the worldwide stereotypes concerning their outlandish behavior, and a way in which they spent a healthy proportion of their paychecks, involved the consumption of alcohol. United States troops drank, and drank heavily. If popular conceptions of Appalachians held any truth, then the mountaineers should have been the ones who led the charge to the bars. Books and popular films had, for decades, promoted the idea of Appalachian hillbillies who spent all of their time either drunk on moonshine, feuding, or both. Popular motion pictures such as Spitfire (1934), Mountain Justice (1938), and Kentucky Moonshine (1938) all embraced the notion of the drunken mountaineer who made his own "spirits" and lazily drank from his whisky jug with his rifle at his side. ${ }^{87}$ Yet, once again in contradiction to the stereotype, numerous West Virginians did not become drinkers until they came into the military, if for no other reason than they had never really been exposed to much alcohol during their youths. Jack Kieffer is one such mountaineer who first experienced drinking after enlistment. His recollection of shipping out from San Francisco serves as an excellent example:

You talk about a place that was crowded. Everybody was wanting a beer. You'd go into this bar and ... they'd

\footnotetext{
${ }^{86}$ John Mangano interview.

${ }^{87}$ Anthony Harkins, Hillbilly: A Cultural History of an American Icon (Oxford: Oxford University Press, 2004), 154-158.
} 
start a bottle of whisky down there pouring and when it got to the end he'd throw it in the trash and then he'd go back to the other end and start over. And we ran across some girls there. They were at the bar drinking and I wasn't a drinker. I had never drank anything in my life till I got over there. We walked around San Francisco all night. ${ }^{88}$

Drinking heavily tended to be a fixture of the American military experience during World War II. In Europe, soldiers commandeered wine and liquor wherever they could find it. Don and Lonnie Brenson, twins who served together in the war, said that sometimes the civilians in Europe gladly gave them free beer. In contraction to the drunken hillbilly, however, Don responded, "We didn't smoke or drink so we used to trade in our cigarettes and beer for candy." ${ }^{89}$ In Asia, troops concocted their own "jungle juice," made from fermented coconut milk or tropical fruits, in order to help cope with the wartime conditions. In one instance, a general was nearly run over by a tank driven by Americans who were drunk on French champagne. Despite efforts from officers to limit the quantity of alcohol available to soldiers near combat zones, civilians in France and Italy fostered a thriving black market, taking advantage of the wealthier American GIs. ${ }^{90}$ In England, drunken U.S. soldiers were so commonplace that they became an annoyance to many locals. William Godfrey noted the stark differences between English social restraint and American gluttony: "I never saw an Englishman,

\footnotetext{
${ }^{88}$ Jack Kieffer interview.

${ }^{89}$ Don Brenson and Lonnie Brenson interview by Jeff Maddox, November 18, 2004, Morgantown, WV, WVVP.

${ }^{90}$ John Ellis, The Sharp End: The Fighting Man in World War II (New York: Charles Scribner's Sons, 1980), 254-258.
} 
civilian or soldier drunk anywhere, but when the pubs and dances closed for the evening, American soldiers were seen staggering along every street. ... We took over rather completely several of the local pubs and the dart games, ales, and spirits." ${ }^{91}$ Golden Crane was also in England. He said, "All we did was train and drink and chase women. ${ }^{, 92}$ Don Louden agreed. Describing his activities after deployment, he simply stated, "There isn't much to do at town except raise hell."93 Jack Birkhimer served in the $82^{\text {nd }}$ Airborne and arrived in Lancaster, England on April 16, 1944, in preparation for the Normandy Invasion. Of the nearly two months he awaited D-Day, Birkhimer said, "We trained a lot, made a few practice jumps, and drank a lot of beer. ${ }^{, 94}$ Another letter from a West Virginian told more of the same. "Nothing much to report except we had quite a party last night. We started off at seven and really raised hell 'till two. There were about fifteen awful sick guys this morning but I felt okay. ${ }^{, 95}$ For West Virginians in the military, taking part in all of the alcohol consumption was not indicative of their Appalachian traits, but of a larger, American trend, furthering the overseas transition from Appalachian to American.

While scores of soldiers drowned themselves in drink so that they may better deal with the harsh reality of war, for the majority of soldiers, it was a way to pass the time and spend their money. American soldiers did not merely drink;

\footnotetext{
${ }^{91}$ Account of William H. Godfrey.

${ }^{92}$ Golden Crane interview by Josh Arthur, March 2, 2002, St. Albans, WV, World War II Interviews, WVDCH.

${ }^{93}$ Don Louden to Phyllis Louden, March 28, 1943.

${ }^{94}$ Account of Jack C. Birkhimer, World War II Records, WVARHC.

${ }^{95}$ Don Louden to Phyllis Louden, May 2, 1943.
} 
they had a lot of fun while doing so. This brings to light yet another aspect of the war. As I have mentioned earlier, somewhere between $85 \%$ and $90 \%$ of soldiers in the U.S. military did not see actual combat during the conflict. For those who did not, reaping the benefits of a decent paying job and traveling around the world led them to see the war as a positive experience. As unbelievable as it may seem, amid the carnage, killing, and devastation of history's most terrible man-made disaster, a sizable percentage of Americans truly saw World War II as "the good war." They were young men escaping home with disposable income. It is hardly surprising that many of them enjoyed themselves. One soldier's letter home described one of many military sponsored events orchestrated to keep the morale of the men high. He wrote, "We went to a big military ball. It sure was nice. A big band, a lot of girls in evening dresses and a swell auditorium. ... We sure were living high on the hog." 96

Even in Asia, men away from the combat zone found means of entertainment. Earl Richmond, who flew on B-29 bombing raids as a radio operator into Burma and China, spent his spare time hunting. Richmond even went elephant hunting in India, describing his time there as a "rewarding" experience. ${ }^{97}$ After the war, John Kaites wrote fondly of his spare time in the South Pacific. "The enjoyment we took part in after duty hours is something to recall - playing

\footnotetext{
${ }^{96}$ Don Louden to Phyllis Louden, May 8, 1943.

${ }^{97}$ Earl C. Richmond interview by Matthew Stephenson, May 4, 2002, St. Albans, WV, World War II Interviews, WVDCH.
} 
ping pong, volleyball, and baseball." ${ }^{, 98}$ While in Australia, troops took advantage of their proximity to the beach and did not hesitate to brag about their leisure time to the folks back home. "The most fun now is swimming. Go quite often and really have swell times." When they were not swimming, men such as Paul Atkins spent time playing games with other GIs. "Been playing lots of rummy with fellows in the tent lately," ${ }^{99}$ he wrote, "Just finished several hot games of pingpong." In another letter to his mother, Atkins wrote, "Blew the last game after a 12-2 lead, so decided to quit and shower." ${ }^{, 100}$ R. F. McClure spent the war deployed in South America guarding a Brazilian shipping port that sent supplies to Europe. With good local food and a nice local bar, McClure thought "it was a private little utopia."

Even for a British soldier who was stationed on an American base at Yalta, life was described in grandiose terms. "It was wonderful, wonderful. Truly it was wonderful. All the soldiers had local girlfriends, the climate was idyllic, food and drink were ridiculously cheap, there were excellent facilities for sport, and on Thursdays we would go sailing with friends." ${ }^{102}$ Of all the West Virginia narratives, no one seemed to enjoy his time in the war more than Lester Hudson who, while enjoying the fruits of the victory in Europe, sounds as though he was describing a family vacation to Austria: "Vienna was one beautiful place. ... It

\footnotetext{
${ }^{98}$ Account of John Kaites.

${ }^{99}$ Paul Atkins to his mother, November 15, 1943, Paul A. Atkins Collection, WVARHC.

${ }^{100}$ Paul Atkins to his mother, July 16, 1944.

${ }^{101}$ Account of R.F. McClure, World War II Records, WVARHC.

${ }^{102}$ Philip Ziegler, Soldiers: Fighting Men's Lives, 1901-2001 (New York: Alfred A. Knopf, 2002), 218.
} 
was good there. In fact, while I was in Vienna we had about a twenty-one piece orchestra that played at dinner time in the evenings. I lived in one of the German general's big summer home, believe it or not. It was great. I mean, it was fantastic. The food there was perfect. I mean out of this world. You would not believe how I lived there for a couple of months." ${ }^{103}$ To be on the winning side and far from the fighting made life very nice indeed. For a time, at least, being simply American was better than being in depression weary Appalachia. The mountaineers had more money at their disposal than ever before in their lives, they were given more respect than in America, and they enjoyed themselves - particularly when it came to the women.

\section{War and Sex}

The fraeuleins, with everything to gain, cooperated very well. One day, shortly after we entered Germany, my jeep was parked off a street in Stolberg. I was changing a flat tire when I felt someone tapping on my shoulder. I looked up at a pretty young girl. She said in perfectly clear English, "Do you hate me?"104

When the soldiers of the Second World War were not fighting or drinking, they were often having sex. The incident mentioned above by William Godfrey in his written account of the war was fairly typical of the GI experience. Throughout the cities and villages of Europe, local women often welcomed American soldiers

\footnotetext{
${ }^{103}$ Lester R. Hudson interview by Matthew Thorn, December 2, 2004, Point Pleasant, WV, WVVP.

${ }^{104}$ Account of William H. Godfrey.
} 
as liberators. With many of the towns in ruins and with a depleted supply of young men, women were very receptive to the conquering Americans. ${ }^{105} \mathrm{~A}$ few scholars have argued that women, dealing with a defeated and decimated culture adopted a submissive policy towards Americans and looked to the soldiers as protection in a chaotic, war-torn world. ${ }^{106}$ Regardless of the reasons, evidence shows that U.S. troops were extremely sexually active during their service. A military study towards the end of the war indicated that fifty percent of all married U.S. soldiers cheated on their wives while $80 \%$ of all single troops had sex with multiple partners throughout their military tenure. ${ }^{107}$ One GI even claimed that "the average soldier who landed at Utah Beach and survived to take Germany, the man who was neither stud nor sissy, probably slept with something like twentyfive women during the war."108

The high command in the United States military took notice of this information and tried to curb the sexual appetites of young men abroad. Before they went overseas, American soldiers were given a pamphlet by the American Legion entitled, "Fall In." They told the soldiers not to "allow yourself to become involved with the other sex in such a way as to impair your health and your future. ${ }^{109}$ For the military brass, this directive was not a moral imperative as

\footnotetext{
${ }^{105}$ Kennett, G.I.,, 194-195.

${ }^{106}$ Petra Goedde, GIs and Germans, 202-206.

${ }^{107}$ Brandt, No Magic Bullet: A Social History of Venereal Disease in the United States Since 1880 (Oxford: Oxford University Press, 1987), 165.

${ }^{108}$ Ellis, The Sharp End, 275.

${ }^{109}$ Quoted in, Mark P. Parillo, ed., We Were in the Big One: Experiences of the World War II Generation (Wilmington: Scholarly Resources, Inc., 2002), 15.
} 
much as a functional one. Soldiers who were carelessly promiscuous risked contracting venereal diseases (VD). At times during the war, more American soldiers were hospitalized for VD than for combat wounds. The typical VD victim spent an average of twenty days in the hospital, taking up huge amounts of space, medicines, hospital beds, and doctors' hours that could have been better served dealing with battle wounds. To make their soldiers feel shame, a number of U.S. military hospitals in the field separated the VD cases from the rest of the troops with a barbed wire fence. The designated VD area was called "Casanova Park." Whenever the famous reporter Ernie Pyle asked a colonel for the purpose of the nickname and the barbed wire, the colonel responded, "It's just to make them feel like heels." 110 Other methods used to try and "shame" the soldiers into remaining chaste included an extensive poster campaign. Military posters used images of disappointed wives and children with slogans like, "I let "em all down," or "VD can be cured but there's no medicine for regret." ${ }^{, 11}$ Others portrayed VD as a seductive woman walking arm in arm with Hitler and Hirohito. ${ }^{112}$ When deterrents failed, safe sex was promoted. According to one study, the United States Armed Forces freely distributed a staggering fifty million condoms a month to soldiers. Even more astonishing is that officers often complained that their men were not being supplied with enough prophylaxis. ${ }^{113}$

\footnotetext{
${ }^{110}$ Ellis, The Sharp End, 273-274.

${ }^{111}$ Brandt, No Magic Bullet, 164-165.

${ }^{112}$ Ibid.

${ }^{113}$ Ibid., 163-164.
} 
Contributing to the problem of soldier promiscuity and VD were the overwhelming presence of prostitutes and organized brothels near military bases and in occupied towns. This was, of course, nothing new. Prostitutes have followed armies as long as there has been war. During World War II, the armed forces of both Axis and Allied countries often either turned a blind eye or actively supported prostitution for their troops. The British Army, for example, provided brothels throughout their colonies for white soldiers. ${ }^{114}$ The Japanese government went a step further, providing jungun ianfu (comfort women) for their troops. In the Japanese case, many of the prostitutes were young girls abducted from Korea and forced to become sex slaves. ${ }^{115}$ Rape, both organized and tolerated, were also fixtures of Japanese invasion of China and the brutal conflict between Germany and the Soviet Union. ${ }^{116}$

The United States attempted to adopt a better policy. Within its continental borders, legislation made it a federal offense for an enlisted man to solicit a prostitute and local law enforcement was extensively used to enforce this law

\footnotetext{
${ }^{114}$ Grant G. Simpson, ed., The Scottish Soldier Abroad, 1247-1967 (Edinburgh, Billings and Sons, 1992), 153.

${ }^{115}$ The Japanese government is still reluctant to admit the existence of the jungan ianfu during World War II. See B. A. Robinson, "Japanese Sex Slavery Before, During, and after World War II," http://www.religioustolerance.org/sla japa.htm; Dai Sil Kim Gibson, "The Women's International War Crimes Tribunal on Military Sexual Slavery," http://www.twotigers.org. ${ }^{116}$ The most obvious example in Asia would be the Rape of Nanking, see Iris Chang, The Rape of Nanking: The Forgotten Holocaust of World War Two (New York: Penguin Books, 1997); For accounts of rape on the Eastern Front, see Gottlob Herbert Bidermann, Derek Zumbro, trans., In Deadly Combat: A German Soldier's Memoir of the Eastern Front (Lawrence: University Press of Kansas, 2000) and Nikolai Litvin, Stuart Britton, trans., 800 Days on the Eastern Front: A Russian Soldier Remembers World War II (Lawrence: University Press of Kansas, 2007).
} 
around the training camps. Police met with mixed success. ${ }^{117}$ Once the troops left the coast, control of prostitutes became even more difficult. One West Virginian stationed in Honolulu said that brothels could be found all over the island. "If you wanted to go to a sporting house or a house of ill repute, or whatever you call it, you stood in line. They was about twelve or fourteen of them there." 118 In war-torn places, prostitution was even more rampant. Thousands of women in the large European cities, left homeless in the wake of bombings or left as widows because of the war, began selling themselves to fend off starvation for themselves and their children. In Naples, Italy, women sold their bodies for a little as twenty-five cents. Many young American soldiers did not hesitate to take advantage of the situation. ${ }^{119}$

Even more interesting about the American troops is the fact that they seldom needed to rely on prostitution to satisfy their sexual appetites. One study showed that nearly $90 \%$ of the military VD cases on the continental United States did not come from prostitutes, but from willing single women. Such women, often referred to as Victory Girls, Good Time Charlottes, and Khaki-Wackies, mingled with soldiers at military balls, local pubs, and U.S.O. parties. ${ }^{120}$ In their letters home, mountaineers readily bragged about how women reacted to seeing "men in uniform." Don Louden, of Fairmont, and his friends rented a car and drove around

\footnotetext{
${ }^{117}$ Ibid., 162.

${ }^{118}$ Albert Buck Taylor interview by Matthew Mitchell, March 21, 2002, St. Albans, WV. WVDAH.

${ }^{119}$ Kennett, G.I., 203-205.

${ }^{120}$ Brandt, No Magic Bullet, 167.
} 
the countryside while stationed Colorado. To his mother, he wrote, "That car sure was a beauty and did the girls ever whistle when we drove by. I think this was the most fun I've had since I've been in the Army." ${ }^{, 21}$ In another letter, Louden described a U.S.O. dance and highlighted his reluctance to settle for just one lady. "Marie was there so I spent the early part of the dance with her but some guys cut in on us several times and I don't like to spend too much time on one girl so I started tagging some little old girl. She was one of the cutest girls at the dance and I'm going to see her tonight." ${ }^{122}$ Similar stories were told in letters from soldiers overseas. One West Virginian stationed in Australia wrote:

I didn't do a single thing except play and rest for four days. The second day there, Cecil and I met two Aussie girls on The beach and the other three days had six dates with them (every afternoon and nite [sp.]). We four spent the days swimming In the ocean - laying around on the beach playing beach ball Cards, etc. Never enjoyed myself more! ${ }^{123}$

William Godfrey, writing of his time in Britain declared, "The soldier [in England] didn't have to look far to find a girl who would go out with him, and the moral standards of most of them were not very high. According to the British Government this was due to the psychological influence of the war." ${ }^{, 124}$ While the American GIs may have been resented by some British males, the females loved them. British women felt that the American men had better hygiene, they smelled

\footnotetext{
${ }^{121}$ Don Louden to Phyllis Louden, May 8. 1943.

${ }^{122}$ Don Louden to Phyllis Louden, May 2, 1044.

${ }^{123}$ Paul Atkins to his mother, November 25, 1943.

${ }^{124}$ Account of William H. Godfrey.
} 
better (Americans used cologne and bathed more often), their uniforms looked classier, and they had better teeth. ${ }^{125}$ Imagine West Virginians who, back in the states, were considered to have bad teeth and poor hygiene, suddenly admired and complimented by the ladies in foreign lands. Certainly, this was a major reversal in perception. William Schnupp, who had been injured at the Battle of the Bulge, returned to England and spent his time in the pubs. "The girls liked me because I was on crutches." He remembered. "They want to come home with me. Guys were marrying them and bringing them back to the U.S. ${ }^{, 126}$ In a few cases, the only barriers to relations between U.S. men and English ladies were bits of confusion caused by the spoken accents of the two parties. According to one story, an American GI approached a British lady during his first night in London and asked, "Say honey, what do you do about sex over here?" The lady smiled and responded, "Oh, we do be having our tea at about that time." ${ }^{127}$ Even the soldiers in Asia found willing partners where they went. One mountaineer remarked, "My stay in India wasn't too bad. Sometimes I even managed to date a white woman." 128

The promiscuity of soldiers at home and abroad during the war threatened to unsettle established notions of sexuality in America. Historian David Allyn marks the beginning of the sexual revolution with the publication of Helen Gurley Brown's Sex and the Single Girl in 1962. This publication, according to Allyn,

${ }^{125}$ Fussell, The Boys' Crusade, 16-17; Longmate, The GIs, 50-55.

${ }^{126}$ William Schnupp Interview.

${ }^{127}$ Longmate, The GIs, 57.

${ }^{128}$ Account of Daniel Kessler, World War II Records, WVARHC. 
launches an avalanche of open discussion concerning women's sexuality and helped paved the way for the sexual liberation of women in America during the social upheaval of the 1960s. ${ }^{129}$ However, the "sexual revolution," just like the modern civil rights and women rights movements in the latter half of the twentieth century, had its roots in the Second World War. It first began with the acceptance of male promiscuity among the military ranks. Unlike, World War I, when complete abstinence was officially promoted, the military brass became a bit more accepting of men's sexual activity. One medical officer explained, "We cannot stifle the instincts of man, we cannot legislate his appetite. We can only educate him to caution, watchfulness and the perpetual hazards of promiscuous intercourse; and furnish him with adequate preventive measures." ${ }^{, 130}$ While the military conceded to the sexuality of males, females who helped satisfy the "male appetite" still faced considerable social scrutiny in American society. But things began to change, if only for a time. During the war, Americans were willing to accept women in the workplace in order to secure an Allied victory, so long as traditional gender roles were not going to be permanently altered. ${ }^{131}$ It appears as though sectors of American society were also willing to accept the sexual escapades of soldiers alongside a promotion of female sexuality in order to sustain the morale of the men in arms. In what may be termed as "sexuality for victory"

${ }^{129}$ David Allyn, Make Love, Not War: The Sexual Revolution, an Unfettered History (New York: Little, Brown, and Company, 2000), 10-11.

${ }^{130}$ Brandt, No Magic Bullet, 162-164.

${ }^{131}$ See Karen Anderson, Wartime Women: Sex Roles, Family Relations, and the Status of Women During World War II (Westport: Greenwood Press, 1981), 6-9. 
women, in West Virginia and elsewhere, were encouraged to flaunt their looks and sex appeal to soldiers in the name of the war effort. This may come in the form of Victory Girls or Good Time Charlottes at military balls as well as in printed form. Examples of this "sexuality for victory" came from the pages of Frankenberger's Sports Page of the Air, a printed version of West Virginia's most popular radio sports program. The show, hosted by Max Frankenberger, covered local, as well as national, sporting events such as high school football and major league baseball. An illustrated printed version was sent each month to thousands of GIs from the Mountain State. ${ }^{132}$ The periodical tried to boost morale by giving troops a little news from home. But Frankenberger's morale boosting went beyond mere sports. Each issue featured numerous pinups and photos of girls in two piece bathing suits (the bikini was a new feature of World War II, brought on by nylon and textile rationing) ${ }^{133}$ and other scantily clad outfits. Some of the ladies featured were professional models, while others were local girls who won contests for being the "prettiest war worker" in a certain town. For example, the front page of the August 1943 issue featured a photograph of a girl in a miniskirt holding an American flag. The caption below read, "What does this have to do with sports? Nothing - but how would you like to have her carry the flag for your regiment? We suggest you write your Congressman." ${ }^{134}$ A provocative pinup of a woman on the front page of the December 1943 issue was accompanied by the following

${ }^{132}$ Frankenberger's Sports Page of the Air, August 1943 to April 1946, WVWHCR.

${ }^{133}$ John W. Jeffries, Wartime America: The World War II Home Front (Chicago: Ivan R. Dee, 1998), 31.

${ }^{134}$ Frankenberger's Sports Page of the Air, August 2, 1943, WVWHCR. 
caption, "This is a special Christmas present from the editor. We hope you like this little package. Her name is Ann Corio, burlesque strip teaser. Are you thoroughly teased? Then you might be interested to know she has just been granted a divorce. Get in line, Buddy!"135

One of the regular pinup features of Frankenberger's Sports Page of the Air were the West Virginia Cowgirls, a group of six female dancers dressed in boots, short skirts, and cowboy hats. The Cowgirls performed dances for the benefit of the war bond drives and posed for photos to be sent to West Virginia soldiers. A caption under a group photo of the Cowgirls during the November 1944 issue asked the troops, "How would you like to be an Indian and get lassoed by one of these Mountaineer Cowgirls?" Frankenberger's claimed to have received over 5,000 letters from GIs requesting the addresses of the Cowgirls. ${ }^{136}$ In addition to pinups and photo teases, the paper sponsored a contest, in conjunction with WCHS radio in Charleston, in which local single women competed in a quiz contest to get the privilege of going to a military base and being a West Virginia GI's valentine. ${ }^{137}$

The above evidence suggests that both West Virginia men and women may have participated in a more sexually open world during the war. The captions accompanying the photos mentioned often spoke of sexual desire and even divorce in a matter-of-fact way that would have been unacceptable before the war. While

${ }^{135}$ Frankenberger's Sports Page of the Air, December 1, 1943, WVWHCR.

${ }^{136}$ Frankenberger's Sports Page of the Air, January 3, 1944, June 13, 1944, and November 1, 1944, WVWHCR.

${ }^{137}$ Frankenberger's Sports Page of the Air, March 1, 1944, WVWHCR. 
this wartime sexuality was not seen as permanently socially acceptable, it was, at the very least, tolerated. The military tried to curb the sexual appetites for men, but found them too difficult to control in the field. The propaganda campaign against VDs was met by an equally aggressive "morale" campaign led by civilian journalists and citizens who sent the boys pin ups and promoted (or exploited) women's sexuality for the men. While this does not necessarily date the beginnings of the sexual revolution as early as 1941, it does serve as a preamble to the sexual openness of later decades in American history. Just as women were able to enter the workforce for the war effort, a few were also, on a limited basis, encouraged to display their sexuality for the same reasons. It would be impossible to consider that the sexual adventures of GIs and the women of America and abroad did not have a ripple effect on the next generation of Americans.

Of course, not every GI away from the combat zone spent his time womanizing. At times, GIs sincerely missed and remained faithful to wives and sweethearts back home. Patrick Gainer's letters reveal a sincere love for his wife, a longing to be with only her, and once more, the isolation and remoteness felt by an Appalachian abroad. "It seems strange to be so far away from you that I am four hours ahead of you in time, and when I am going to bed you are probably just having supper." He wrote to her, "I lie awake and wonder what you are doing. There isn't much to say except how much I want you." ${ }^{138}$ On another occasion, he penned, "Your letter does me so much good. It is wonderful just to know that you

${ }^{138}$ Patrick Gainer to his wife, August 22, 1945. 
are all well and happy. I like to hear about what you are doing, for it brings you closer to me - even away out here." 139 And in yet one more example: "I want to make you happy so much. When I come home I will show you. It seems that there are so many things I want to tell you, and when I start to write there is only one thing I can think of - how much I want to be with you." Gainer is clearly not having the time of his life while abroad and, even though he did not see any combat, the distance from home appeared to be the source of his misery. "It seems that we must be together soon and never be separated again. When I dream about you it seems that you are near and I have not had any bad dreams for a long time. $" 140$

Those who truly loved the women they left behind did not forget them.

Whenever possible they made every attempt to maintain a feeling of intimacy despite the censorship of their letters. This is Hershel Williams' story:

They did tell us that our letters would be censored. Every letter that you wrote would be read by a censoring officer, and if you mentioned anything in there as to where you were, what you was doing, that would be cut out. ... So I wrote my girlfriend, who would be my wife as soon as I came home and has been ever since. But I wrote to her and we worked out a deal where I would write a letter and the first letter of the paragraph would be the letter starting up where I was. Just an example, Guam. First paragraph with a "G" and then I'd write a great big bunch of stuff, and then the second paragraph I would make a "U" out of it, and so on, until I spelled out the word "Guam." If she would take every first letter of the paragraph it would tell her where I was. So, I shipped out of California and the first place that I got stopped was New

${ }^{139}$ Patrick Gainer to his wife, August 23, 1945.

${ }^{140}$ Patrick Gainer to his wife, August 31, 1945. 
Calidonia, and you can imagine what kind of letter I had to write. I mean, it was like a Sears and Roebuck Catalog. . . . Then, I shipped out of there and I shipped to the next place, Guadalcanal. Well, there I went again with the Sears and Roebuck catalog ... but, [the letter] made it, [my girlfriend] knew where I was by doing that. ${ }^{141}$

After the war, Williams married his girlfriend. At the time of the interview, they had been together for nearly sixty years.

\section{Conclusion}

James Stewart never really expected to travel far beyond his hometown of Dunbar, West Virginia. However, the events of World War II carried him through North Africa, Sicily, and all the way to the doorstep of the great Roman Coliseum. Staring at the famed ancient structure, once a hallmark of the most powerful economic and military force of the western world, a combat soldier of the newest great western juggernaut then proceeded to do something very American - he made his mark. Stewart stalked around the ruins until he found a little, obscure stone somewhere on the inner wall, pulled out his army knife, and carved his initials right there on the Roman Coliseum. While on vacation many years later, he took his daughter back to Rome so that she could see where her father had made

${ }^{141}$ Hershel Woodrow Williams interview by Charles King, March 21, 2002, South Charleston, WV, World War II Interviews, WVDCH. 
his little mark on history. ${ }^{142}$ While many would find Stewart's actions to be irreverent and disrespectful, it is not hard to imagine a Roman legionnaire doing something very similar to the Egyptian ruins after the conquests of Julius Caesar. And, in fact, they did. Roman graffiti can be found alongside Egyptian hieroglyphs on dozens of tombs and ancient Egyptian temples. ${ }^{143}$ The point is that conquerors, whether in a just or unjust war, make their mark upon the lands they cross and those that they defeat. American troops were no different. Before the war, West Virginians were seen as originating from an Appalachian culture far removed from mainstream American life. What we find from the experiences of these soldiers in a non-combat setting, is that they behaved in a way very similar to soldiers from all over the United States. They took over local pubs, had affairs with local women, freely spent their money, and interacted with other cultures in ways that ran the spectrum of friendly, compassionate, disrespectful of tradition, and sometimes racist attitudes. Natives of the various lands seemed to have made little or no distinction between Americans regardless of region, ethnicity, or race. In short, the experiences of mountaineer soldiers abroad in World War II culminated in a transition from an Appalachian identity to an American one.

The seminal question then becomes, why did American troops behave in this manner? Was the soldiers' practice of wastefully spending their money on booze, womanizing, and having a good time unique to the American, and perhaps

\footnotetext{
${ }^{142}$ James Stewart interview by Bill Noel, May 2003, Dunbar, WV, World War II Interviews, WVDAH.

${ }^{143}$ See http://www.thebanmappingproject.com/articles/article_2.4.htm.
} 
even more so with the Appalachian, experience of the war? Did the reality coincide with a common British saying during the war that the Americans had a reputation of being, "overpaid, oversexed, and over here?"144 Furthermore, if this was a behavior unique to the experience of Americans, then does it not serve as evidence for legitimizing national stereotypes? Would this not validate the concept of using stereotypes to define "national character?" Scholars who wrote during the World War II era would argue that this was the case. In their eyes, everything from Japanese atrocities committed against the Chinese, to German war crimes committed by the Einsatzgruppen, to simple American braggadocio, were all indicative of inherent national characteristics. But not everyone on the American side behaved the same way. The West Virginia war narratives show a strain of individualism among the soldiers. Some treated different cultures with sympathy and respect, while others did not. Some womanized and some remained faithful. Thus, not everyone adhered to the stereotypes associated with Americans. While this study does not delve deeply into the non-combat experiences of soldiers in the other countries, it is safe to assume that not everyone's behavior in the British, Japanese, Soviet, and German forces fit with popular stereotypes associated with their cultures either. Nevertheless, the fact remains that the majority of Americans did appear abrasive to their Allied hosts, the majority did overindulge in drinking, and promiscuous, sometimes vulgar, sexual behavior. It is most plausible to conclude that the non-combat behavior of

${ }^{144}$ Fussell, The Boys' Crusade, 19. 
armed forces in World War II, particularly the American behavior, varied because of the distinct circumstances confronting each separate military force. American soldiers acted rambunctiously because they could afford to do so. With higher salaries and so many of them away from the combat zone, they were simply able to enjoy themselves more, and they did. Because they were welcomed as liberators, they were able to have many sexual adventures. On the Eastern Front, with fighting so much more extensive and brutal, and driven by different ideologies, soldiers behaved in distinctive ways towards civilians in those warravaged lands. The same was the case in Asia. United States troops did not drink or womanize as much as in Europe because women and booze were not as readily available. Immediate circumstance, more so than national traits, helped to dictate the behavior of soldiers. As we shall see, for those who experienced the terror of combat, immediate circumstance would influence beliefs and behavior even more. Once the shells began to explode and the bullets started to fly, the narratives of West Virginia soldiers transformed even further. If the non-combat experience overseas changed the men from Appalachian to American, the world of combat would strip nearly all the soldiers from their supposed national, cultural, and ethnic traits, leaving them with nothing but their shared humanity. 


\section{Chapter Four}

\section{From Americans to Humans}

The following quotes come from letters written by soldiers who fought on opposite sides in World War II. Two of the passages were written by Germans while the other was written by a West Virginian.

Each time I write I think about our coming anniversary and wonder whether you will receive this letter on that day. I am sorry I could not send you something, but all I can send you now is my love. I'll make up for everything some day. If we can just pull through this period of separation and then be together again always. I hope we never quarrel again. Goodnight by beloved wife. I love you with all of me. ${ }^{1}$

I live on this anticipation, especially since yesterday morning ... everyday I mark a day on my calendar, and every mark means that I am a day closer to you. ${ }^{2}$

I took out your picture once again and looked at it for a long time. I remember the experience we shared that lovely summer evening in the last year of peace when we found each other for the first time. We talked about ourselves and about the future which lay before us like a many layered carpet. That carpet is no longer there and we are no longer together. . .

Without knowing the origins of each letter, it is virtually impossible to ascertain the nationality of the authors. The similarities in each of the letters

\footnotetext{
${ }^{1}$ Patrick Ward Gainer to his wife, 15 June 1945, Patrick Ward Gainer Papers, West Virginia and Regional History Collection, Morgantown, West Virginia (hereafter cited as WVARHC).

${ }^{2}$ Franz Schneider and Charles Gullans, eds., Last Letters from Stalingrad (New York: William Morrow and Company, 1962), 45. Names and dates in this translated collection of letters have been omitted, but they come from surrounded German troops in the Battle of Stalingrad.

${ }^{3}$ Ibid., 21.
} 
quoted above stand out far more than any perceivable differences. Each soldier professed a longing for their loved ones and each of them desired to return to their homes. References to nationalities and declarations of cultural values are not found in these texts, rather, it is the common values that each letter shares which strikes the reader most. Historian John Morton Blum has observed that the fundamental goal of every American soldier in World War II was to go home and his biggest wish was for the war to end. ${ }^{4}$ There are few scholars who would disagree with Blum's argument. As will be demonstrated later in this chapter, multitudes of soldiers from every army in the war clung to the very same wishes and goals. But if this is true for the average soldier in World War II, then the historian is confronted with a seemingly obvious but deceptively complicated question: if nobody wanted to fight, why was everybody fighting?

There are literally thousands of books that deal with the causes of World War II. Scholars have offered up class analysis, trumpeted the destructive power of nationalism, pointed accusations at the Treaty of Versailles, and even examined the racial element of the war. The truth is that there is no single cause for the Second World War. A combination of many factors contributed to the outbreak of war and reasons vary from political, to ideological, to diplomatic, to economics. As noted throughout this work, stereotypes also played an important role in the war because soldiers from every army often sincerely felt that their enemy was

\footnotetext{
${ }^{4}$ John Morton Blum, V was for Victory: Politics and American Culture During World War II. (New York: Harcourt Barce Jovanovich, 1976), 55-57.
} 
fundamentally different than they were. Before one can fully appreciate the historical significance of the similarities in soldiers' combat narratives, however, one must come to a better understanding of why and how men from all around the world were deceived into believing that the stereotypes of their enemies were true.

Stereotypes and the Causes of

The Second World War

There is perhaps no period in world history where stereotypes are more widespread than in the Second World War. Everywhere, it seems, ethnic groups, races, nationalities, and cultures were accused (and sometimes self-glorified) as being distinct from everyone else. As historian Omer Bartov puts it, "The twentieth century has been the site of a titanic struggle over competing conceptions of humanity. This struggle was waged not merely in the minds of intellectuals and in university lecture halls, but also in the popular media and on the streets of great cities, on battlefields, and in concentration camps." ${ }^{, 5}$ Thus, when putting the stereotype of violent mountaineers into its proper perspective and applying it to the Second World War, we find that using stereotypes to construct cultural identity was a crucial component in the root causes of why and how the

\footnotetext{
${ }^{5}$ Omer Bartov, Mirrors of Destruction: War Genocide, and Modern Identity (Oxford: Oxford University Press, 2000), 4.
} 
war itself was fought. Just like the dual perception of the Appalachian, stereotypes were used in pairs to build up one culture and tear down another.

One can almost completely summarize Adolf Hitler's goals for Germany and National Socialism in two words: Volksgemeinschaft and Lebensraum. Historian Jackson J. Spielvogel defines Volksgemeinschaft as an ideological vision that would "unite all Germans in a racially pure community." 6 This ideal promoted the superiority of the Aryan race, while denouncing the inferiority and advocating the exclusion other groups - most notably Jews and Slavs. ${ }^{7}$ This triumphant German culture, once achieved, would need its Lebensraum or "living space," which Hitler intended to gain by conquests in Eastern Europe. Hitler outlined this ultimate vision in his book Mein Kampf and spent the next twenty years trying to achieve these goals. The implementation of nearly all Nazi policy, from the Nuremburg Laws, to the annexation of Austria, to the Holocaust, to the invasion of Poland, to Operation Barbarossa fit under the umbrella of either Volksgemeinschaft or Lebensraum. ${ }^{8}$

This frightful ideology was largely based on the notion that different cultures and races possess certain inherent traits. In the Industrial Age, while American writers such as John Fox Jr., and John C. Campbell were "discovering" a unique, violent culture in Appalachia, German writers across the Atlantic were constructing the cultural identity of another group, one they called the Aryans.

\footnotetext{
${ }^{6}$ Jackson J. Spielvogel, Hitler and Nazi Germany: A History, (New Jersey: Prentice Hall, 1996), 6.

${ }^{7}$ Ibid., 6-7.

${ }^{8}$ Ibid., $42-43$.
} 
Historian Heather Pringle, in her 2006 book The Master Plan: Himmler's Scholars and the Holocaust, traces the origins of the Aryan concept in Central Europe to German writers such as Friedrich Schlegal, Theodor Benfy, and Hans Gunther. In what Pringle calls "a masterpiece of racial stereotyping," these writers constructed a mythological ancient race, whom they credited with founding the Indo-European languages and cultures. ${ }^{9}$ According to these authors, the modern Aryan, who is largely Germanic, possesses inherent traits of "boldness, self-reliance, sound judgment, a love of justice, a deep well of energy and creativity, a gift for storytelling and musicianship, and a talent for warfare." ${ }^{\prime 10}$ These ideas appealed specifically to right-wing German Nationalists during the age of Bismarck and Wilhelm II and later were zealously adopted by Hitler, Himmler, and the Nazis. Some historians look to extreme nationalism as the main cause of World War II, but it must be remembered that a very significant component of this nationalism in Nazi Germany was the idea that their culture and race were superior to others. ${ }^{11}$ While the Nazis latched on to this ideal, they also used stereotypes to justify the persecution of other groups. German historian Joachim Fest writes that the Nazis had "mythologized themselves" and, in their rise to power, "they had needed enemies, had derived their self-assurance from these enmities, had virtually defined themselves by them, and wherever such enemies were lacking,

\footnotetext{
${ }^{9}$ Heather Pringle, The Master Plan: Himmler's Scholars and the Holocaust (New York: Hyperion, 2006), 27-35.

${ }^{10}$ Ibid., 37.

${ }^{11}$ Ibid., 38-45.
} 
they has spared no effort to create them."12 One of the chief enemies were Jews, and propaganda was the first weapon the Nazis would use. On March 14, 1933, Joseph Goebbels was sworn in as Reich Minister for Popular Enlightenment and Propaganda. One of his primary goals was to sell the concept of Volksgemeinschaft to the German people. He would immerse himself into this task with great verve, championing the Aryan race and demonizing the Jew through the radio, newspapers, and party rallies. ${ }^{13}$ Of course, the Nazis did not need to concoct their own stereotypes of Jews, but rather drew upon prevailing, old stereotypes of them in order to paint the image of Jews as inherently "greedy, conniving, and dishonest swindlers." ${ }^{14}$ According to the Nazis, the Jews controlled international banks and Bolshevism, they, not the Allies, were responsible for the Treaty of Versailles and stabbing the German Army in the back. After all, was not the Weimar Constitution written by Hugo Preuss, a Jew? Was not Karl Marx a Jew? Because Jews made up only around 1\% of the population in 1933 and were concentrated in a small number of the major cities, it was easy, according to historian Avraham Barkai, for the Nazis to convince many Germans of these stereotypes because most Germans had little or no direct daily contact with Jews.

\footnotetext{
${ }^{12}$ Joachim Fest, Inside Hitler's Bunker: The Last Days of the Third Reich (New York: Farngr, Straus, and Giroux, 2004) 127.

${ }^{13}$ Ralf Georg Reuth, Goebbels (New York: Harcourt, Brace, and Company, 1993), 172-190. Goebbels was so enthusiastic about portraying the Jews as devils that even Hitler, before the Nazis had gained complete power over the German government, told the propaganda minister that he was being "too aggressive." ${ }^{14}$ Avraham Barkai, "Volksgemeinschaft, Aryanization, and the Holocaust," The Final Solution: Origins and Implementation, David Cesarini, ed., (London: Routledge, 1994), 38.
} 
The Nazis preyed upon popular ignorance and used stereotypes to build the Aryan up and tear the Jew down. We all know the catastrophic results of this ideology. ${ }^{15}$

Meanwhile in the Pacific, the Japanese were resurrecting old beliefs in the warrior code of Bushido in order to tout the idea of a superior Japanese culture. ${ }^{16}$ In the years leading up to the war, "the Japanese portrayed themselves as being historically purer than other peoples genetically and morally - an assertion they buttressed with theories about the divine origins of the Yamato race." ${ }^{, 17}$ Again we see the idea of inherent traits embedded within a culture. Japanese military leaders not only embellished these traits, they counted on them. Ronald H. Spector argues that Japanese military strategists, when faced with the possibility of war against the United States, heavily leaned on the ideal of "the superior toughness, morale, and fighting spirit of their men - the unique 'Japanese Spirit' which had won the day against the larger forces of China and Russia."18

We also see that the Japanese sought to impose stereotypes on their enemies. Just like Nazi propaganda, the Japanese government used an all encompassing media and educational indoctrination to construct the idea of Americans as cruel, inhuman, and bloodthirsty. As John W. Dower phrases it, Americans were the "demonic other" whose imperialistic nature and selfish

\footnotetext{
${ }^{15}$ Ibid., 35-42.

${ }^{16}$ Victor Davis Hanson, Carnage and Culture: Landmark Battles in the Rise of Western Power (New York: Anchor Books, 2001), 360-361.

${ }^{17}$ John W. Dower, War Without Mercy: Race and Power in the Pacific War (New York: Pantheon Books, 1986), 215.

${ }^{18}$ Ronald H Spector, Eagle Against the Sun: The American War With Japan (New York: Vintage Books, 1985), 45.
} 
individualism threatened Japanese hegemony in Asia and the Pacific. ${ }^{19}$ The Japanese soldier must show no mercy, because the American barbarians would show none to the people of Japan. This propaganda worked so well that American soldiers in Saipan faced a horrifying sight when they witnessed scores of Japanese women killing their own children and committing suicide because they believed that Americans would rape, torture, and do unspeakable things to them. ${ }^{20}$

If cultural characteristics were given as a solid reasoning for implementing racial policies and warmongering, they have also been used to explain the rise of tyranny before World War II. Some German historians of the post-World War II era, such as Hans-Ulrich Wehler, have written about the German "special path," or Sonderweg theory, which traces German traits of militarism and nationalism on an inevitable path from Bismarck to Hitler. ${ }^{21}$ If this idea has been largely discredited by German scholars, some Japanese historians still look to cultural traits for explaining the Axis defeat. Mitsuo Fuchida and Masatake Okumiya claim:

In the final analysis, the root cause of Japan's defeat . . . lies deep within the Japanese national character. There is an irrationality and impulsiveness about our people which results in actions that are haphazard and often contradictory. ... Indecisive and vacillating, we succumb readily to conceit which, in turn, makes us disdainful to others. $^{22}$

\footnotetext{
${ }^{19}$ Dower, War Without Mercy 255-258.

${ }^{20}$ Ibid., 45.

${ }^{21}$ Richard Evans, Rereading German History, 1800-1996 (London: Routledge, 1997), 2-3. The Sonderweg theory has gone through two versions. The first, in the years before World War II, claimed that is was a "special path" to greatness. After the war, some claimed it was a "special path" to catastrophe.

${ }_{22}$ Mitsuo Fuchida and Masatake Okumiya, Midway: The Battle that Doomed Japan (New York: Bluejacket Books, 2001), 247.
} 
Strangely enough, Fuchida and Okumiya ignore significant historical data, such as a higher population in the United States, the overextension of the Japanese Empire, and the fact that the United States was producing sixteen ships for every single one the Japanese could produce. Astonishingly, even in defeat, the idea of cultural traits remains as a viable explanation for historical events. ${ }^{23}$

As we have seen with the portrayal of the violent Appalachian, cultural stereotypes were abundant even in America. After the attack on Pearl Harbor, the U. S. government and mass media portrayed the Japanese as "monkeys" and the "yellow peril" in order to arouse feelings of hatred, fear, and inferiority towards the new enemy. Meanwhile thousands of Japanese-Americans were put into internment camps because they were seen as a threat to national security. ${ }^{24}$ African-Americans also were targeted. As thousands of African-Americans patriotically signed up for military service, they found that they were not allowed to fight. Instead, they were mostly sent to serve in mess halls. ${ }^{25}$ When civil rights leaders such as A. Phillip Randolf openly questioned the reasoning behind this unfair treatment, Secretary of War Henry Stimson responded, “A relatively large percentage of the Negroes inducted in the Army have fallen within the lower educational classifications, and many of the Negro units have accordingly been

\footnotetext{
${ }^{23}$ Hanson, Carnage and Culture, 341.

${ }^{24}$ Dower, War Without Mercy, 21-31.

${ }^{25}$ Christopher Paul Moore, Fighting for America: Black Soldiers - The Unsung Heroes of World War II (New York: One World Books, 2005), 130-133.
} 
unable to master the techniques of modern weapons. ${ }^{26}$ In other words, the government fell back on a stereotype that African-Americans were less intelligent than whites, so they were sent to the kitchens instead of the front lines.

Everywhere throughout the war, we find that stereotypes were used to construct cultural identity while perceptions of cultural identity often dictated, or were used to explain, military and political policies.

This study is certainly not the first to highlight this aspect of the war. Indeed, a number of historians have even referred to World War II as a race war, while others use nationalism as an explanation for much of the evidence shown above. ${ }^{27}$ The analysis of this study simply goes a step further, suggesting that extreme nationalism and racism had their roots partly, if not entirely, in the construction of cultural stereotypes. The overarching point is that millions of human beings in the Second World War justified the killing of other humans by glorifying their own culture and demonizing others. If hillbilly cartoons and degrading novels may seem harmless and funny to some, and mild in comparison with other stereotypes of the time, numerous examples during World War II demonstrate how dangerous stereotypes can be when used in the name of nationalism, racism, and political idealism. In his book, Mirrors of Destruction: War, Genocide, and Modern Identity, Omer Bartov finds a link between cultural constructs and violence in the twentieth century. "We cannot understand the

\footnotetext{
${ }^{26}$ Neil A Wynau, The Afro-American and the Second World War (New York: Holms and Meier, 1976), 3132.

${ }^{27}$ See Dower, War Without Mercy, 1-8.
} 
manner in which individuals, ethnic religions, ideological groups, and nations perceive themselves or interact with others without considering the impact of our century's preoccupation with violence. ${ }^{28}$ Understanding how stereotypes and violence are intertwined in the Second World War is crucial to coming to a more accurate conceptualization of cultural identity, Appalachian, American, German, Japanese, or otherwise. Cultural stereotypes drench World War II like a tempest. At the very least, stereotyping in the war led to mocking caricatures and misconceptions of other cultures. At its worst, it culminated in genocide and mass slaughter.

Behind nearly every stereotype is a motive. Concerning many Appalachian stereotypes and the evolution of Appalachian identity, mountaineers have often been portrayed in many ways in order to suit the motives of an outside industrialist, journalist, academic, or politician. Sometimes mountaineers have been generalized in order to justify the exploitation of their land and resources in the industrial age. At other times they are painted as a people who need to be saved in order to fund settlement school projects or to bolster the careers of politicians and journalists who hope to gain national prominence. Author John O'Brien observed that "Appalachia had wheels on it. It rolled around the mountains and, like a traveling circus of hillbillies, stopped wherever the

\footnotetext{
${ }^{28}$ Bartov, Mirrors of Destruction, 6.
} 
politicians wanted it to stop." ${ }^{29}$ This phenomenon is not unique to Appalachia. Numerous groups are generally stereotyped in order to achieve some purpose. Unfortunately, throughout Appalachian, and even world history, the motives behind generalizing groups have often been sinister. Such was particularly the case during the Second World War.

As this study has endeavored to demonstrate, in the case of Appalachians, the stereotypes associated with mountaineers were sometimes grossly exaggerated and, more often than not, completely false. Nowhere is this more evident than on the battlefield. For if the Second World War was filled with many ironies, there is no greater irony than this: while the belief in stereotypical views in the enemy influenced humans to killing other humans in combat, it is on the common experience of the battlefield where all the distinguishing stereotypes of race, ethnicity, nation, and culture are the most clearly eradicated. There are other scholars who have reached similar conclusions. Concerning the First World War, Niall Ferguson wrote, "anyone seeking fundamental differences of national character will look in vain in the records of the trenches." ${ }^{30}$ It was in the trenches, Ferguson argued, that a common humanity far outweighed the differences of the various combatants. The same is the case in the Second World War. This chapter will focus on four aspects of the battlefield experience that dissolve almost all

${ }^{29}$ John O'Brien, At Home in the Heart of Appalachia (New York: Anchor Books, 2001), 52 .

${ }^{30}$ Niall Ferguson, The War of the World: Twentieth Century Conflict and the Descent of the West (New York: Penguin Books, 2006), 118. 
variations of national, ethnic, cultural, and racial differences. These are the common denominators: 1) the physical environment of modern war, 2) the fear and uncertainty of combat itself, 3) the reality of killing and of death and 4) the ways in which the soldiers cope with combat. Thus far we have witnessed the transition of mountaineer identity from peace to war, from local to Appalachian, and from Appalachian to American. With the reality of the battlefield, we will see their transition from American to human.

The Physical Environment

\section{Of Modern War}

Modern war can be a powerful unifying factor within nation-states. In both of the World Wars, the majority of populations in countries around the globe met their governments' declarations of war with strong feelings of nationalism and patriotism. Whether the country went to war as aggressor or defender, citizens rallied around the banner of their nation and, for the most part, dutifully served their leaders. ${ }^{31}$ Even in places like the Soviet Union, where the populace labored beneath one of the most oppressive regimes in human history, Joseph Stalin was able to muster considerable unity in what many Russians termed the "Great Patriotic War." Granted, the Soviet Union was invaded and many Soviets fought not specifically for Stalin but to repulse an invader. Nonetheless, large percentages

${ }^{31}$ John Keegan, The Second World War, (New York: Penguin Books, 1989), 26-30. 
of the men who left their homes marched willfully under Stalin's flag. ${ }^{32}$ At the beginning of war, it seemed as though nearly everyone wanted to fight for his country. Victory or defeat often heavily influenced the attitudes of the soldiers. American troops, for example, largely felt more pride in their country at the war's end. ${ }^{33}$ Japanese soldiers who felt the pangs of their government's failure to achieve victory felt somewhat differently. Upon the conclusion of the war, a Japanese soldier bluntly remarked, "a world without states seemed best of all. The nation didn't matter to me anymore." ${ }^{, 4}$ The point is that no matter their country or class or race or culture, men from incredibly diverse backgrounds marched towards a singular unifying experience of destruction and killing. The only world truly without states was the one on the battlefield, where death and survival proved to be greater motivators than any national ideology. The first aspect of this unifying experience was the physical environments playing host to the battles themselves.

This study has already established the impact of the new environments on West Virginia soldiers throughout their military service. Their narratives remarked upon the distinguishing and varying features of their homeland, the isolation they felt on the Pacific islands, the architecture of European antiquity, and the equally harsh conditions of the desert sun and tropical rain. The new environments impacted their psyche and their identity. Nowhere is this more evident than on the

\footnotetext{
${ }^{32}$ Martin Malia, The Soviet Tragedy: A History of Socialism in Russia, 1917-1991 (New York: The Free Press, 1994), 275-280.

${ }^{33}$ Studs Terkel, The Good War: An Oral History of World War II, (New York: The New Press, 1994), 558-574.

${ }^{34}$ Cook and Cook, Japan, 291.
} 
battlefield where soldiers of all sides were equally subjected to rain, snow, mud, heat, and cold, causing them to share a "common bedrock of suffering" due to the climate. ${ }^{35}$

The two world wars have much more in common than is typically credited by scholars. For the soldiers in combat, a great deal of the war was experienced from a hole in the ground. While the types of weapons changed between wars, one instrument kept its fundamental significance - the shovel. Soldiers of both wars dug in to protect themselves from modern industrialized weapons. The only major difference between the First and Second World Wars was that, in the first one soldiers usually stayed in the same hole while in the second troops simply moved from one hole to another. ${ }^{36}$ When it rained, men lived in mud holes. An English soldier fighting in Italy even remarked that "the greatest enemy by far was the mud." ${ }^{, 37}$ An American officer expressed it by saying, "the cumulative psychological effect of mud is an experience which cannot be described." ${ }^{38}$ When the mud was gone and it was sunny, soldiers battled with dust, sand, and heat, often for days and even weeks at a time. Being stuck in the tropical heat and dryness also heavily impacted the mental stability of the troops. "The sun and the sand, the sea and the unvaried scenery seem to leave the mind to rot and stagnate

\footnotetext{
35 John Ellis, The Sharp End: The Fighting Man in World War II, (New York: Charles Scribner's Sons, 1980), 28.

${ }^{36}$ Ellis, The Sharp End, 28-29.

${ }^{37}$ Ibid., 16.

38 Ibid., 17.
} 
like a sultry swamp." ${ }^{39}$ Filth in every theatre permeated the foxholes, and soldiers had few opportunities to clean or bath themselves. "Sometimes you didn't get to shave for a month," remembered Junior Scott of Pinch, WV. He recalled, "we'd use our helmets as wash pails. The simple things didn't seem very important while you were over there. There was always something going on that you had to be aware of and shaving just wasn't one of them. Ever since I came home, I've shaved every day, though." 40

Living in the foxholes affected other basic aspects of normal existence. One mountaineer wrote, "I went through many things that would have frightened the average person but I was young and stupid. The only thing that bothered me was sleep! I never could get any sleep. ${ }^{, 41}$ Constant shelling and gunfire could keep men awake, but the natural climate also contributed to the lack of sleep afforded the combat troop. In the dry, hot foxholes of North Africa, the climatic conditions alone kept soldiers from rest. Once the soldiers dug in, they found the holes a haven for unwelcome guests. One soldier remembered, "as soon as we settled down the native rats started. One of them ran across my face and scratched my nostril with his sharp claws. They kept running over my body, and when I dozed off, they started nibbling my hair." ${ }^{42}$ In North Africa, soldiers could not sleep because of the sweat pouring down their bodies and the flies biting at their skin. In

\footnotetext{
${ }^{39}$ Gerald F. Linderman, The World Within War: The America's Combat Experience in World War II (New York: The Free Press, 1997), 347.

${ }^{40}$ Junior L. Scott interview by Elisha Scott, April 19, 2004, Pinch, WV, WVVP.

${ }^{41}$ Account of Clyde Reed, WWII Records, WVARHC.

${ }^{42}$ Ellis, The Sharp End, 24.
} 
the Pacific, the mosquitoes had a similar impact. ${ }^{43}$ When the mosquitoes, flies, and rats were not harassing the men and adding to their lack of hygiene and sleep, worms feasted on the bodies of the dead, turning the stomachs of friend and foe alike. A Japanese soldier observed that "dead bodies were everywhere. White worms covered the bodies. Millions of worms in human shapes, rustling just like reeds. You'd see a dead man's glasses moving because of worms. Moving as if he were alive. ${ }^{, 44}$

Another common enemy shared by troops on many fronts was the coldness of winter. Nowhere was this more apparent than in Russia where the winter was most severe. According to one German soldier, "the cold numbed and deadened the human body from the feet up until the whole body was an aching mass of misery. . . . Everyone felt brutalized and defeated by the cold. ${ }^{, 45}$ In the winter of 1941-42, the snow could cover the tracks of men within minutes, men's hands froze inside their gloves, horses could not stand because of ice on the roads, and machinery ceased to operate. When a German officer found a young replacement troop, newly arrived on the Russian front huddling around a fire, he told the new soldier to count himself lucky that it was only ten degrees below zero. The officer told the young troop that within a month the thermometer would drop to twenty-

\footnotetext{
${ }^{43}$ Ibid., 20-21.

${ }^{44}$ Cook and Cook, Japan, 279.

${ }^{45}$ Stephen G. Fritz, "Frontsoldaten: The German Soldier in World War 2 (Lexington: University Press of Kentucky, 1997), 110.
} 
five below. "At this, the poor fellow broke down and sobbed." ${ }^{46}$ As the Germans suffered, so did others. Mountaineers, it appeared, were just as likely to freeze from the cold as anyone else. William Schnupp was sent into the Battle of the Bulge as part of the reinforcements. On the way to the battlefield his train was hit by German artillery and he, injured but still alive, had to hobble to the nearest base. The winter quickly enhanced the pain of his wounds. "I was limping. I couldn't get my boots off. My legs were frozen above the knees. Both legs were frozen. They took a pin and went up my legs in the medic tent to see how much of my legs were frostbit. ${ }^{, 47}$ Fred Stats also found the winter in Europe miserable. "It was so bad in there. Cold. Your feet freeze in the mud in the foxhole, and it'd rained, snowed and froze and laying in that stuff trying to get a little sleep of a night, you know. Shells a-falling too, and I don't think there's any way to describe how horrible it was. ${ }^{48}$ Whatever side a soldier found himself fighting for, the environment hit him with an overwhelming tenacity. Everyone suffers in the cold, everyone gets wet in the rain, and everyone is miserable in the mud. If different ideologies and varying necessities brought men to the battlefield, the rats, worms, and insects did not have any bias towards one side. They feasted on the attacker and the defender, the just and the unjust. Not only did the physical climate attack each army with equal tenacity, but one can find no distinguishing "cultural

\footnotetext{
${ }^{46}$ Ibid., 108-109.

${ }^{47}$ William Schnupp interview by Matthew Schnupp, December 15, 2004, Wheeling, WV, WVVP.

${ }^{48}$ Fred R. Statts interview by Margaret Scharf, February 9, 2002, Pinch, WV, World War II Interviews and Papers, WVDCH.
} 
otherness" in the reactions of soldier narratives. The above examples suggest that the complaints of a German, Englishman, or Japanese could just as easily have been interchanged with those of a mountaineer.

\section{The Fear and Uncertainty \\ of Combat}

General William C. Westmoreland is quoted as saying, "war is fear cloaked in courage. ${ }^{, 49}$ No one can express surprise that newspapers and the war propaganda machines of each nation-state involved in the war hoisted the virtue of courage under fire and tried to celebrate the courage of their respective fighting men. Certainly courage was to be found on every battlefield, and there are abundant examples of mountaineers performing their duties with bravery. Of the 218,665 West Virginians serving in the military during the war, eleven West Virginians received the Congressional Medal of Honor while dozens more were recognized with the Silver Star, Distinguished Service Cross, Distinguished Flying Cross, and the Legend of Merit, among other awards. ${ }^{50}$ Journalists were quick to tout the heroic exploits of West Virginians whenever such examples presented themselves. They told of how Lawrence Selak rescued several of his men after a

\footnotetext{
${ }^{49}$ Quote found at http://www.thinkexist.com/quotation/war/war_is_fear_cloaked_in_courage/206836.html. ${ }^{50}$ James G. Jones, "West Virginia in World War II," Ph.D. Dissertation, West Virginia University, 1952, 402-403.
} 
tank was bombed. ${ }^{51}$ They wrote of Jimmy McCartney who, along with four other Americans, captured fifty-four Germans in Tunisia. ${ }^{52}$ They celebrated the achievements of Joseph M. Waterman who scored several direct hits in his fighter over the Solomon Islands. ${ }^{53}$ Any researcher scanning the West Virginia newspapers from 1942 to 1945 can find daily examples of courage at the front. Public glorification of warriors in the midst of war is to be expected. Stories from the front helped boost morale and motivated individuals on the home front to support the war effort. The stories also emphasized how individuals from a particular region contributed to their country's victory. It is also no surprise that while courage was emphasized the fear experienced by men at the front did not find its way to the front page of the Sunday edition. Without a doubt, courage existed everywhere, but it was only one of a prism of emotions running through the minds of soldiers in war. The following narrative exemplifies this complexity of emotions:

People ask, what is it like to be in combat? This is a difficult question to answer. With combat comes many strange feelings. You know that at any moment you might fall dead or be seriously wounded, but you haven't the time to worry about the death that is whistling around you. The time of serious thoughts of life and death, home and the future come before and after an attack. The moment before actual fighting you're scared, scared stiff. Your thoughts are a mile a minute - home, the objective, what to do, when to do it, did you get the plan across to the men, will the attack be successful, your

${ }^{51}$ Morgantown Post, May 7, 1943.

52 Ibid., May 11, 1945.

${ }^{53}$ Ibid., May 6, 1943. 
tongue is dry, what time is it, glad you wrote that letter last night, wish this was over, time to go..., 54

The above passage was written by Rudy Barie, a mountaineer attending West Virginia University in 1946, but one can easily imagine similar thoughts racing through the mind of any soldier from any army during the war. Predictably, the soldier mentions his longing for home, a recurring theme amongst fighting men everywhere. There are, however, two other significant themes: fear and uncertainty. If the author of the above narrative was a typical product of an inherently violent culture, it would seem unlikely that he would find himself "scared stiff" in the moments before the fighting began. The narrative, then, does not fit neatly into the category of an "Appalachian" narrative, but rather, a more generalized human narrative that expresses general emotions shared by anyone. These emotions that so prominently reveal themselves in soldier narratives combine to form the second common denominator found among combat veterans of the Second World War. A German soldier's description of the mood of himself and his comrades before battle echoes the sentiments expressed by Rudy Barie.

We sat on the gun carriage drinking warm coffee in an attempt to dissipate the cold feeling within us. Everyone decided to appear nonchalant and spoke of things not associated with the war, attempting through conversation to conceal the anxiety clearly etched in sun burned faces. ${ }^{55}$

${ }^{54}$ Account of Rudy Barie, WWII Records, WVARHC.

${ }^{55}$ Gottlob Herbert Bidermann, Derek Zumbro, trans., In Deadly Combat: A German Soldier's Memoir of the Eastern Front (Lawrence: University Press of Kansas, 2000), 19. 
Anxiety and anticipation contributed to the fear felt by soldiers on the eve of battle. But a question remains, what exactly did soldiers fear? A simple answer would be death or injury. It is only natural that men approaching battle should feel anxiety over the possibility of imminent annihilation on the battlefield.

Surprisingly though, many soldiers did not expect death before their first experience with combat. Initially, they usually expected others to die, but not themselves. Gerald Linderman's study of combat soldiers in the war reveals that the concept of death in the mind of the soldier evolves through several stages. In the days prior to any actual combat, soldiers feel a kind of invincibility. This invincibility later erodes to vulnerability upon the actual experience of combat, and from vulnerability to fatalism after extended periods at the front. ${ }^{56}$ But in the beginning, at least according to Linderman's argument, fear of death is not overly prevalent. One veteran reminisced about this idea of invincibility. With a dangerous assault only a few hours away, his battalion commander told the group that the whole battalion except for one or two of them would probably die on their mission. "The remark bit deeply into every man present," the soldier said. "Each glanced at his comrades with undisguised compassion. 'Gee,' each man thought to himself, 'those poor fellows.,",57

If not death, then what was it that put fear into the hearts of inexperienced troops? One Russian soldier's comments give us another possibility. "Was I

\footnotetext{
${ }^{56}$ Linderman, The World Within War, 7-17.

${ }^{57}$ Ibid., 8.
} 
scared? Maybe, but I was really afraid that the men would see my fear." ${ }^{\text {,58 }}$ The point is stated indirectly, but is there nonetheless - this Red Army soldier is worried that he might, in some way, let his comrades down. The fear of not performing well in battle and of not "doing his part" permeated in the minds of troops far more than idealism, training, patriotism, or any type of cultural traits that may have prepared him for battle. The comradeship formed within the confounds of war bonded men together to such an extent that they were willing to march that extra mile, dig another foxhole, and shoot another enemy for the sake of their buddy next to them. The Germans referred to this soldierly bond as Frontgemeinschaft: Americans often used the term "foxhole buddies." According to a British officer, the fear of not performing one's duties and holding steadfast for one's "fellow lads" was a healthy and, indeed, necessary part of success in battle. ${ }^{60}$ The officer's comments are further validated by a West Virginia marine who stated, "on the fourth day, about two in the morning, I was awakened by loud booming sounds. I arose and went quickly to the top deck where I could see what was going on. I noticed that our LST had stopped and I could see flashes of gunfire in the morning skies. I knew that this was it!! I felt

\footnotetext{
${ }^{58}$ Evgenii D. Moniushko, Oleg Sheremet, trans., From Leningrad to Hungary: Notes of a Red Army Soldier, 1941-1946 (New York: Taylor and Francis Group, 2005), 100.

${ }^{59}$ Stephen Bull and Gordon L. Rottman, Infantry Tactics of the Second World War (New York: Osprey Publishing, 2008), 33-34.

${ }^{60}$ Philip Ziegler, Soldiers: Fighting Men's Lives, 1901-2001 (New York: Alfred A. Knopf, 2002), 64.
} 
week and scared of what lay ahead but some force seemed to carry me on." ${ }^{61}$ The marine's name was Sammy Adams, and despite his fear, he mentions a mysterious force that enabled him to perform his duty. The force of which he spoke may well have been the very fear of not performing his duty. Thus, in the preliminary stages of the combat experience, soldiers everywhere used this particular type of fear as motivation for performing their duties.

New types of fear would take hold after fighting began. John Mangano had just entered a French village with his platoon when he was first fired upon by German troops. They heard noises and began searching for the enemy; they "just kind of roamed around to see what the hell, what the hell was going on, you know. Boy, oh boy. Something came up the street just a firing, fiery red. Just buzzing. Bzzzzz, bzzzzz. We got the hell out of the way then. We knew it was real then."62 Mangano's experience reveals the impact that the first enemy fire has on the individual. It is when the gunfire begins that fear contributes to washing all other ideologies away. Only survival and duty remain. "These Jerries sure know how to fight," wrote Paul Richard to his parents in West Virginia as he described his first encounter with the Germans. "We pulled up to within range of the enemy artillery when they opened fire. You could see every man turn chalk white. It wasn't long before we had our foxholes dug and you couldn't see a man in sight. But we were

61 Account of Sammy Adams, WWII Records, WVARHC.

${ }^{62}$ John Mangano interview by John Gianola, April 15, 2004, Sabraton, WV, WVVP. 
there and Jerry knew it. We wouldn't be greenhorns for long." ${ }^{.63}$ Enemy fire quickly became another source of fear for the combat soldier. In retrospect, Richard expresses dread at the mention, and implication that he and his comrades would be exposed to enemy artillery. Richards expressed a common fear. Of all the devises of the enemy, including booby traps, snipers, landmines, and machine gun fire, nothing put fear into a soldier more than artillery. United States troops particularly feared the German $8.8 \mathrm{~cm}$ gun above all others. ${ }^{64}$ Artillery not only added to the fighting man's sense of fear, but to his sense of uncertainty. Valor is irrelevant in the face of enemy artillery. Whether or not one survived had little to do with one's individual actions. Being caught under a barrage could make a man feel "as helpless as a leaf tossed in the whirlwind" 65 regardless of how inherently violent or otherwise he may be. One soldier commented that artillery fire from the Germans was so loud and he felt so helpless. He stated, "I came as close to dying from fear as I ever will.,

In soldier letters, while not using the word "uncertain," left a strong impression that they understood the fragility of their lives in war. Writing to his mother, Paul Atkins implied his uncertainty rather than mentioning it straight away. "This is very hurried as I haven't any time," he wrote. "We are again in combat and you probably know where but as yet I won't say. Whatever happens I

\footnotetext{
${ }^{63}$ Paul Richard to his parents, October 13, 1944, West Virginia War History Commission Records, WVARHC.

${ }^{64}$ Bull and Rottman, 11-12.

${ }^{65}$ Linderman, The World Within War, 15.

66 Ibid.
} 
love you always and you know how much. ${ }^{, 67}$ Clearly, Atkins did not know if he would be alive the next day and thus, felt compelled to say what was most important to him in the event that he did not survive. Uncertainty even affected the burial of the dead, as a Russian soldier noted:

We bury our dead comrades in the evening ... comrades in arms, with whom we didn't have time to get acquainted. Two short speeches. The earth falls with a dull sound. Flashes of officers' handguns punctuate the darkness. I salute with everyone. The grave is marked on the commander's map, but there is no marker here. Who knows who will be in possession of this land tomorrow or the day after? ${ }^{68}$

Modern war, with its automatic guns, bombers, and long range artillery gave the combat soldier a feeling of randomness. Men seemed to die for no reason at all, other than they were unlucky enough to be in the wrong place at the wrong time. Anyone could get killed and even the privilege of rank could not protect a man. "Men had to be men there. Enemy bullets hit the officers as well as the enlisted men," one soldier recalled. "I shall forever be sorry that so many bullets hit the good officers and left the rest for us to put up with." ${ }^{, 9}$ Soldiers were periodically overcome with the notion that the best of them did not survive. They also often fought an enemy they could not see and were killed by the bombs of those who could not see them. Soldiers additionally came to feel that luck dictated who died

${ }^{67}$ Paul A. Atkins to his mother, October 26, 1944, Paul A. Atkins Collections, WVARHC.

${ }^{68}$ Moniushko, From Leningrad to Hungary, 102.

${ }^{69}$ Account of Stanley Reckart, WWII Records, WVARHC. 
and lived and men gave in to a mindset of "complete vulnerability." ${ }^{, 70}$ Fred Stats recalled that "it's a terrible feeling for someone to be shooting at you, you know. People getting killed all around you and you wondered why you didn't get it, you know. Yeah., ${ }^{, 11}$ Another West Virginian paints an unforgettable picture of helplessness and uncertainty during the war in his recounting of a Japanese air raid:

Amid the bomb bursts I saw one of my friends crawling towards my pit without the use of his right arm. Blood was pouring from his side as if someone had hit him with an axe. There were screams of pain all around me as I jumped up to help my buddy into the pit. Then I saw another fellow running across the field toward another shelter. Just then another blast came rolling in over us. After the dust cleared, where that kid was I saw a shoe lying on the ground where he was running and hoped God would have mercy on his soul. Then it was quiet and I knew the raid was over. I yelled for a medic who helped me carry the fellow with the missing arm to the first aid tent. I never saw him again. I can't explain why, but I went away so no one could see me and tried to hide the tears that were rolling down my face. Once again my Mother and Dad had been spared their son. I guess I'm not so tough after all. ${ }^{72}$

The victims of bombings were not the only ones to feel helplessness. It could also be felt by those who took part in the bombing. Rob Cox, from Lewis County, served in the Air Force and flew on B-17 bombing missions. Flying from England, he bombed railroads south of Berlin. "The day I flew my mission the sky was clean and cold," he stated. "The Germans had determined our altitude and

\footnotetext{
${ }^{70}$ Lindserman, 26-27.

${ }^{71}$ Fred Statts interview.

${ }^{72}$ Account of Daniel Kessler, World War II Records, WVARHC.
} 
speed and. . the sky was filled with black puffs of smoke from the bursting shells." He watched German fighters attack other B-17s. "However, we were not attacked," he concluded, "and a few minutes later I made myself comfortable for the long ride home., ${ }^{, 73}$ Anti-Aircraft fire and opposing planes could make those in the sky feel just as vulnerable as those on the ground. Joseph Doyle was a gunner on a B-24 and flew missions for three months in Europe. They were "full of excitement. The nearness of death in a crash landing, leaky gasoline tanks and faulty engines made me wonder if I would live.,74

The uncertainty of combat could weigh on a person's psyche to the extent that they wonder if their service is making any difference at all. "In a man's mind, there remains a little hope," Stanley Reckhart wrote. "In the face of all this, he still hopes that perhaps he is doing his little bit. I still am hoping that I had done some good; I have no way of ever knowing certainly." ${ }^{, 75}$ The battlefields of World War II spread fear and uncertainty to everyone who experienced it firsthand. As Stats' remarks illuminate, the reality of death and killing would further cement the shared bond of mountaineers. Significantly, their narrative accounts of combat would reflect their common humanity over their Americanism.

Death and Killing on the Battlefield

\footnotetext{
${ }^{73}$ Account of Robert Cox, WWII Records, WVARHC.

${ }^{74}$ Account of Joseph Doyle, WWII Records, WVARCH.

${ }^{75}$ Account of Stanley Reckart, WWII Records, WVARHC.
} 
Veterans who write or talk about their experiences in modern war struggle the most when it comes to describing the world of combat. Some of the veterans who were interviewed outright refused to speak of battles in any detail, as they were overcome with bad memories. ${ }^{76}$ Those who have detailed their combat experiences to interviewers or put their memories to paper give us depictions of war with more sincerity and emotion than any civilian ever could. However, the writings and interviews of West Virginia soldiers not only tell us about the front lines of World War II, they tell us something crucial about the soldiers themselves. Since the men of Appalachia were thought to have inherited a unique culture that fostered violence, nowhere should their supposed bloodlust be more apparent than in their stories of battle. The quintessential questions of this study then becomehow did the presumed violent mountaineers react to the ultimate form of violence and do their reactions reveal the stereotypes to be true? There is no greater litmus test than the battlefields of mankind's largest armed conflict. Did men coming from a culture of guns enjoy using them? Finally, how did their reactions compare with those of other veterans?

Military studies after the war showed surprising evidence that a multitude of American troops did not relish the idea of shooting anyone, even the enemy. It was common for troops to shut their eyes before they shot at a man. Occasionally

\footnotetext{
${ }^{76}$ Among many other examples see Wayne Martin Interview by Joanna Ross and Monica Cutlip, November 19, 2004, WVVP; Steve Riffon interview by Jonathan Dodd and Matthew Thorn, December 2, 2004, Morgantown, WV, WVVP.
} 
U.S. soldiers refused to fire at all, paralyzed by what was happening all around them. ${ }^{77}$ They all knew that they were supposed to kill. In fact, they were trained to shed their sanctity of human life for the purposes of war. Taminaga Shozo, a $2^{\text {nd }}$ Lieutenant from Japan noted what the war did to one's humanity: "Good soldiers were those who were able to kill. We made them like this. Good sons, good daddies, good elder brothers at home were brought to the front to kill each other. Human beings turned into murdering demons., ${ }^{, 78}$ But men did not enter the war as murderers, even if they came from the so-called "murder land of Appalachia."79 Golden Crane remembered the hesitation that he felt when his introduction to combat came during a German attack at Cherbourg, France, in 1944. "The first man I shot at," he remembered, "was this tall German. He was running ammunition to the machine gun position in front of us. I tried not to hesitate, but it was hard not to. I couldn't believe what I was doing." ${ }^{, 0}$ A world away on Saipan, killing also weighed heavily on the mind of Jack Kieffer. "You're wondering where you're at," he pondered, "and what am I doing?",81

Whether or not they wanted to fight became irrelevant once the fight began.

Killing became a necessity for reasons other than achieving victory; it was a

\footnotetext{
${ }^{77}$ Bull and Rottman, Infantry Tactics of the Second World War, 36.

${ }^{78}$ Cook and Cook, Japan, 43.

${ }^{79}$ Anthony Harkins, Hillbilly: A Cultural History of an American Icon (Oxford: Oxford University Press, 2004), 39. Harkins is quoting a series of popular articles written by a New York journalist after the turn of the twentieth century.

${ }^{80}$ Golden Crane interview by Josh Arthur, St. Albans, WV, March 2, 2002, World War II Interviews and Papers, WVDCH.

${ }^{81}$ Jack Kieffer interview by John Simms, St. Albans, WV, April 24, 2002, World War II Interviews and Papers, WVDCH.
} 
means to survive. "Silence filled the air and not a human being was to be seen, but death waited behind a tree or in a cave," one mountaineer wrote of Guadalcanal. "The enemy had infiltrated our lines and it was not noticed until we heard the cry that became so familiar to our ears, the cry of a man being choked to death by the strong piece of fine wire. Every man knew that he must move, that he must find the enemy and destroy him. ${ }^{\prime 82}$ Soldiers may have enlisted for a variety of reasons. Once on the battlefield the soldier could feel stripped of any choice but violence. "We went into the Philippines. That was hard. All the fighting and guys were just falling over and had been shot right beside you and you wanted to get out of there. You wanted to run away from it all but you couldn't because there was nowhere to go. So you just stayed there and fought. ${ }^{, 83}$ Sammy Adams was also resolute about what needed to be done in battle, but his account reveals harsh psychological consequences upon those who killed. His memoir recounts a marine attack on a Pacific island: "I had never seen any of the Japs shooting at me and I still couldn't see them, but as the fog cleared, I saw one creeping towards a wounded marine and I shot him at least a dozen times. I don't feel like writing any more. I am nervous enough now and the horrors I've been through I wouldn't want anyone else to know." ${ }^{, 84}$

${ }^{82}$ Account of Robert Urbas, World War II Records, WVARHC.

${ }^{83}$ Steve Riffon interview by Matthew Thorn and Jonathan Dodd, December 2, 2004, Morgantown, WV, WVVP.

${ }^{84}$ Account of Sammy Adams, WWII Records, WVARHC. 
The remorse over killing and death tells us that West Virginia soldiers took no pleasure from the killing and death going on around them. Such an observation may seem self explanatory and evident. After all, what good-natured American boy would relish becoming a killer? What would have been surprising to many Americans (and may still surprise some) is that the subhuman, evil, and demonic enemy that they fought often felt similar things. One German fighting against the Soviets wrote that "our only thoughts were to flee this nightmare, to escape from this place of filth, misery, and death, far away where no shells would fall. ${ }^{, 85} \mathrm{An}$ even more remarkable account comes from the following excerpt of a German soldier's letter:

On Tuesday I knocked out two T-34s with my mobile antitank gun. Curiosity had lured them behind our lines. It was grand and impressive. Afterwards I drove passed the smoking remains. From a hatch there hung a body, head down, his feet caught, and his legs burning up to his knees. The body was alive, the mouth moaning. He must have suffered terrible pain. And there was no possibility in freeing him. I shot him, and as I did it, the tears ran down my cheeks. Now I have been crying for three nights about a dead Russian tank driver, whose murderer I am. . . . My life is a terrible contradiction, a psychological monstrosity. ${ }^{86}$

Hope of escaping the violence and repulsion to violent acts were not, then, limited to American soldiers. Even the German, who fought for the same regime responsible for the Holocaust, could be overcome by the destruction of war.

${ }^{85}$ Gottlob Herbert Bindermann, Derek Zumbro, trans., In Deadly Combat: A German Soldier's Memoir of the Eastern Front (Lawrence: University Press of Kansas), 59. ${ }^{86}$ Schneider and Gullans, Last Letters, 112. 
General human characteristics overshadow cultural stereotypes in the above examples. However, the unanimity of horror expressed in both German and West Virginia, prompts a complicated question as is illustrated by the following account of a mountaineer who came upon a German concentration camp.

We arrived the day the camp was taken by American troops. The Germans had tried to do away with the camp and prisoners. Dead men tell no lies and they did try to kill them all but we surprised them and took over the camp before SS troops could do too much of their devilish work. Dead bodies were stacked on wagons in long rooms with running water over them. There was at least 3,000 dead bodies around the place. The dead had been shot, gassed, beaten to death, put to death with shots in the head, and any other way that would cause death. This I will never forget as long as I live. ${ }^{87}$

While this passage continues to reflect how West Virginians did not embrace, but were in fact horrified by the violence of war, it also presents an enormous problem. If such a large number of troops from every nationality were disgusted with the horrors of violence in the war, how did so many acts of extreme brutality occur in the war? While this study can in no way fully explain atrocities such as the Holocaust and the Rape of Nanking, as a multitude of scholars have already attempted, the soldier narratives can shed a little light on violence, brutality, and collective identity in World War II. Creating stereotypical identities in order to justify a death camp, as the Nazis surely did, does help provide a partial explanation. While World War II may well be the supreme example in human history when stereotypes are misused to shape cultural identity, it does not explain

${ }^{87}$ Account of Ray Silver, WWII Records, WVARHC. 
why people believed in stereotypes to such an extent as they did, and it does not tell us why so many humans would willingly participate in acts of brutality. ${ }^{88}$ The fact cannot be overlooked that violence breeds more violence and brutality feeds upon brutality. While the war horrified millions it also fostered hatred. While the Holocaust is by far the most extreme example of hatred in the war, it is not the only one, nor was hatred confined to one group. Just as the world of killing and death repulsed many, others used it to fuel their hate. This was another common human experience of the war. In a letter to a friend, one West Virginian expressed this hatred. "I wish you could have been there," he wrote, "and watched some of those S-of-a-B's pay for their sins. I admit it. I hate the Japs and don't want any live ones in my presence." The soldier was aware of what he had become mentioning that he now had a "contaminated mind" and he stated that "war has made me harder and tougher with hate." 89

As violence continued, hatred grew. The war in the Pacific resulted in extreme instances of brutal acts on both sides. The Japanese reacted to American bombings by cutting of the heads of captured pilots. Other times, captured American infantrymen were tortured, killed, and then had their bodies mutilated, sometimes by castration. By contrast there are plenty of examples of American troops using machine guns to mow down lines of Japanese prisoners after they had

\footnotetext{
${ }^{88}$ See Omer Bartov, Mirrors of Destruction: War, Genocide, and Modern Identity (Oxford: Oxford University Press, 2006), 4-6.

${ }^{89}$ Charles Godwin to Bryan Hamilton, January 16, 1944, WVWHCR.
} 
surrendered. Others kept Japanese skulls and bones as souvenirs. ${ }^{90}$ Thousands of soldiers who fought in the Pacific gradually held harsher and more unmerciful attitudes towards the Japanese. This is particularly evident in how many soldiers reacted to the news of Hiroshima and Nagasaki. Nearly every veteran interviewed who served in the Pacific approved of President Harry Truman's decision to drop the atomic bombs. One soldier said, "Truman made the right decision. It saved a bunch of lives." ${ }^{91}$ Another account is even more explicit:

We should've done it sooner! No, I don't feel sorry one bit about that. We were dying over there. I know too many guys that didn't make it back from over there. People talk about civilians. They bombed Pearl Harbor and didn't give a damn about our civilians. What did they expect? Yeah, I don't make no apologies for that. [Truman] should've hit them sooner, and Tokyo too. . . . Guys were dying. I say do it all over again if needed. ${ }^{92}$

That many troops found themselves wanting to kill the enemy is evidence of how warfare transforms civilized humans. Of course, in the minds of most Americans, the unleashing of the Atomic Age was synonymous with the end of the war; therefore, it is understandable how most soldiers would have warmly greeted the news of Hiroshima. Nonetheless, the remorse highlighted in the earlier passages is in sharp contrast to the vengeful attitude expressed in others. If we can

\footnotetext{
${ }^{90}$ John W. Dower, War Without Mercy, Race and Power in the Pacific War (New York: Pantheon Books, 1986), 55-63.

${ }^{91}$ Jack Kieffer interview by John Simms, April 24, 2002, St. Albans, WV, World War II Interviews and Papers, WVDCH.

92 Steve Riffon interview by Matthew Thorn and Jonathan Dodd, December 2, 2004, Morgantown, WV, WVVP.
} 
learn anything from these narratives and how they relate to the war's brutality it is the transformative power of combat. Mountaineers, along with everyone else, did not enter the war as uncivilized men; it was the war that stripped men of their civilization. The shredding of civilized behavior and common decency impacted everyone who fought. The brutality of the war, while expressed with varying degrees at different levels and with different methods, was a universal human consequence of the war and was not confined to specific nations, ideologies, and regional cultures.

\section{Coping With Combat}

Without a doubt, combat in the Second World War eliminated civilization in the hearts of men. In order to cope with the fear, uncertainty, and violence in combat, men of all sides turned to largely two devices - comradeship and faith. Life and death on the battlefield had another universal effect not confined to nationality; it left the men with nothing but one another and any faith in a higher power that they may have. A German soldier remarked upon the comradeship formed in war: "As yet we had not experienced the true effects of prolonged warfare, which becomes an environment that sets aside all former bonds to family and culture and irretrievably replaces them with bonds to the comrade at your 
side." ${ }^{, 93}$ The only one who could truly understand the misery of an individual

soldier is one who shared in his misery. The shared experiences of battle branded

men together in ways difficult to comprehend and helped them endure the day to

day trials of the conflict. The story of Hershel Woodrow Williams, a

Congressional Medal of Honor winner from southern West Virginia, describes this

bond and commitment to one's fellow soldier with vivid detail.

When we went overseas a fellow of the name of Vernon

Waters, who was a huge Swede who lived in Montana,

northern Montana. He and I became really close friends.

He was six foot six. I'm five foot six. You know, I had to

look up to him whether I wanted to or not. But we became very close friends and, when we got over to Guadalcanal they put Vernon and myself into a special unit, which kept us together. At that time until we got to Iwo Jima, we were closer than any brother than I have had, and I had several brothers....

Each of us wore a ring and mine was a ruby that probably came from a dime store because it turned my finger green. But Ruby is my wife's name and at that time we were engaged. So I wore what she gave to me to remind me that there was a Ruby waiting for me. Well, he had a ring on his right hand that his father had given him in the Marine Corps. It is absolutely a Court Martial offense to remove anything from a deceased marine's body ... but Vernon and I, we didn't know there was such a law when we made the pact that if anything happened to us I will give his ring back to his folks and he will give my ring back to Ruby. And then, on Iwo, on March 7, he got hit with a mortar and he got killed. I ran to him and soon as I got to him, I knew he was dead. But, I saw that ring on his finger and that pact struck me. This is what I promised to do. So, I jerked the ring off his finger before anybody else got there. But, having been in the sun, and for the South Pacific we had lots and lots of sun, and under that ring it was as white as snow. And,

${ }^{93}$ Bidermann, In Deadly Combat, 23-24. 
they would know that somebody would have that ring. So, in order to camouflage that, I grabbed some old black sand which we had lots of around - old, volcanic black sand. I spit in my hand and rubbed that sand and made a little bit of mud out of it and I rubbed that on [his finger] and you could sort of see all the whiteness was still there but, it wasn't what it was before.

So I stuck the ring in my pocket, kept it, and never said anything to one person about it. As I got home in January 1946 my wife to be and I drove to northern Montana about as far as you can go to the Canadian border, and I delivered that ring to Vernon's father. That's the most memorable thing I can remember. ${ }^{94}$

At times soldiers, in an attempt to shield themselves from additional emotional trauma, would try to keep from getting too close to others. New troops who were brought into veteran units to replace injured or killed comrades were often shunned by the battle-hardened soldiers. Concerning replacement men and comradeship, a British soldier remarked, "I don't want to get too close. They die. ${ }^{95}$ But, in battle, bonds would continue to form. This was a universal, not simply an American facet of the war. As stated by one veteran, "I hold it to be one of the simplest truths of war that the thing which enables an infantry solder to keep going with his weapons is the near presence or presumed presence of a comrade. The only thing that kept you going was your faith in your buddies. ${ }^{, 96}$ Soldiers in the same platoon or squad depending on one another to cope was yet another example of the human experience of the war.

\footnotetext{
${ }^{94}$ Hershel Woodrow Williams interview by Charles King, March 21, 2002, South Charleston, WV, World War II Interviews and Papers, WVDCH.

${ }^{95}$ Ziegler, Soldiers, 42.

${ }^{96}$ Linderman, The World Within War, 269.
} 
Faith also played a significant role. Most of the soldiers interviewed after the war said that when the "going got tough" prayer enabled them to stay sane.

Researchers were told that they actually became more religious in the Army. Some units even prayed together before going into battle. ${ }^{97}$ Eighty-three percent of combat veterans in Italy admitted to praying frequently in combat. ${ }^{98}$ A sizeable percentage, like Fred Statts, attributed their survival to the mercy of God: "I thought we'd get through it somehow and I did. With the help of the Lord, I guess. Well, I wouldn't want to guess, I know. ${ }^{99}$ Others noted how soldiers became more religious minded the closer they approached fighting zones.

Perhaps the most interesting feature of the whole voyage to me was watching church attendance grow as we came nearer to the objective. Services were held in the early evening on the fan tail of the ship. Seven days off [the coast] there were perhaps 200 in attendance. Four days off, there was at least 700. The evening before, it was impossible to get closer than a far hearing distance to the Chaplain. ${ }^{100}$

The dependence on faith only intensified under the stress of battle, as another mountaineer attested:

Without warning, a formation of Jap planes came over from out of nowhere and started dropping Easter Eggs, only it wasn't Easter. It seemed as if it were raining bombs and all of us were hoping and praying that our name wasn't on one of those drops of death. I dropped into a drainage pit and hugged the earth and prayed for my life. It seems that when men have fear in

\footnotetext{
${ }^{97}$ Kennett, G.I., 138-139.

${ }^{98}$ Linderman, The World Within War, 75.

${ }^{99}$ Fred R. Statts interview by Margaret Scharf, February 9, 2002, Pinch, WV, World War II Interviews and Papers, WVDCH.

${ }^{100}$ Account of Jim Collier, WWII Records, WVARHC.
} 
their hearts they turn to God for comfort. I was no different ${ }^{101}$

Dependence on faith, like the other aspects of combat, was shared by

soldiers of other armies as well. Even in the German military, while under a government that hoped to eradicate Christianity, religious faith remained.

"Foresight, strength and faith remained the watchwords during these days," a

German remarked. "We attempted to find comfort through the words of the priests

and chaplains." ${ }^{102}$ A German soldier surrounded by Soviet troops at Stalingrad

shows considerable emotion and religious feeling:

May God hold his hands over you, dear parents for now the evening is at hand. And we will do well to set our house in order. We will go into the evening and the night calmly, if it is the will of the Lord of the world. But we do not look into a night without end. We give our life back into the hands of God! May he be merciful when the hour has come. ${ }^{103}$

No individuals were more attuned to the faith of soldiers and how they used their faith as a coping mechanism than the chaplains who served in the armed forces. The Reverend John J. Mueller, originally from Wheeling, served as a Catholic priest in Lewis County when the United States entered the war. In 1943, Mueller joined the U.S. Army as a chaplain ${ }^{104}$ After attending chaplain school at Harvard University, Mueller, at the age of twenty-three accompanied the $10^{\text {th }}$

\footnotetext{
${ }^{101}$ Account of Daniel Kessler, WWII Records, WVARHC.

102 Bidermann, In Deadly Combat, 67.

${ }^{103}$ Schneider and Gullans, Last Letters, 62.

${ }^{104}$ Joseph J. Tennant to Rev. Joseph Mueller, March 29, 1943, Reverend Joseph J. Mueller Collection, Catholic Heritage Center Archives, Wheeling, West Virginia (Hereafter cited as Mueller Collection).
} 
AAA Group in the Pacific theatre where he would attend to the religious needs of combat troops. ${ }^{105}$ Before Mueller left for the front, he was given the Vademecum for Catholic Chaplains written by Rev. John F. O'Hara. In this booklet, Mueller's religious and patriotic task was laid out before him. It stated: "Your primary duty in the service is to help your men live well - and, if die they must (quod Deus avertat), die well. Waste no opportunities for helping your men live well ... [and] place the souls of your men in touch with God."106 The experiences and extensive correspondence of Reverend Mueller during the war offer another West Virginian's perspective on faith and combat in World War II.

Mueller witnessed battles and death firsthand, and as the war ground ahead, the tone of his letters change along with his role in the military. As chaplain, Mueller fulfilled the role as a spiritual and personal confidant to many troops. They often spoke to him of their homes and family. "The men are always telling me about their children," he remembered, "- how some of them whom they have never seen are now walking and talking." He wrote to his sister, Sally: "It makes it seem ages since we were home." ${ }^{107} \mathrm{He}$ also conducted funerals, administered last rights to those who were dying, and held special masses for those already killed. Especially telling are the many letters Mueller wrote to the mothers and wives of soldiers killed in action. In these letters, Mueller gives candid

\footnotetext{
105 Travel orders, HQ 40 ${ }^{\text {th }}$ Coast Artillery Brigade, February 15, 1944, Mueller Collection.

${ }^{106}$ Rev. John F. O'Hara, Vademecum for Catholic Chaplains of the Armed Forces of the United States (New York: The Military Ordinariate, 1943), 2-3, Mueller Collection.

${ }^{107}$ Joseph Mueller to Mrs. George Hores, April 15, 1945.
} 
descriptions of the funerals of the soldiers. To the brother of Carl Morrison he wrote, “[Carl's] funeral took place on Monday afternoon, October 8. Every possible military honor was rendered. I wish you could have been present. The full funeral service was read at the grave, followed by the firing of three volleys by the firing squad, the folding of the flag, and the sounding of "taps" by the bugler. It was all most impressive." 108

Occasionally, Mueller provided details to family members about the actual death of the soldier in question. The following description, written to Mrs. Anna B. Young, details the death of her son: "Glyn's death occurred during a surprise, night attack on the early morning of January 19 by the Japanese. Glyn was in charge of the defense of his section at the time, and acquitted himself nobly to the task. Perhaps if he had been less brave he might have been spared. But that was not to be. And he was shot, dying almost immediately."109

Mueller also provided words of compassion to grieving loved ones. To the wife of Robert Jenkins he wrote: "His fellow soldiers told me that they had lost a real friend as well as a comrade. Yours, however, is the greatest loss. We realize that. But try to be consoled in the fact that, in giving his life for his country, Robert, in a more particular way, gave his life for you. For, to the average American soldier, his wife and mother and children and sisters are the American

\footnotetext{
108 John Mueller to Walter F. Morrison, October 10, 1945, Mueller Collection.

109 John Mueller to Anna B. Young, January 24, 1945, Mueller Collection.
} 
Way for which he is fighting." ${ }^{110}$ Whenever possible, Mueller tried to offer spiritual consolation to bereaved family members. He wrote the following to the father of Hersal Heal.

There is little that can be said, I know, to console you at this time. But, as I told the men in my little talk at the grave and at the Mass, you and we should be consoled in the fact that Hersel was perhaps as well prepared to face death as a man could be. I personally saw him at Mass, confession, and Holy Communion on Christmas, just the day before. And I, the priest, was with him at the end. What more could anyone ask when his time has come? ? $^{11}$

To Mueller's credit, every letter differed greatly in its form and detail, attributed to the amount of time and care put into his duties. And his efforts did not go unnoticed. Many family members wrote back to Reverend Mueller and thanked him for his candid observations and his spiritual care of their deceased loved one. In this way, one finds that the chaplains not only helped with the spiritual and psychological well-being of the soldiers, but of their families as well. A letter from Anna Young, of Bardwell, Kentucky, typifies the gratitude and concerns of many family members: "I am thanking you so much for writing," she said, in response to Mueller's letter concerning her son's death. "If you can give us any information about having [her son's] body brought back or getting his personal belongings we will appreciate it so much ... May God watch over you all and it is my prayer that this cruel war will soon be over." She ended her letter

\footnotetext{
${ }^{110}$ John Mueller to Mrs. Robert A. Jenkins, September 25, 1944, Mueller Collection.

111 John Mueller to Harold Heal, January 24, 1945, Mueller Collection.
} 
with a post-script that read: “Anything you can tell us about Glyn's life in the Army we will appreciate it. We hadn't seen him in two years."112

While Mueller responded to such letters and offered whatever details he could, the unenviable task of administering emotional support to soldiers and families alike must have taken an enormous emotional toll on the young priest. A hint of this emotional stress and the horrors of war can be found in a letter written to his sister while stationed in the Philippines. The letter was originally intended to wish his sister a happy birthday, but the harsh reality of the war quickly made its way into the text.

I could tell you tales which would wring your heart. But what's the use? [The soldiers] and we will just have to sweat out the mess, and hope for better things to come. You should thank God that none of your boys are old enough for this war. For it is not pretty, this war, any aspect of it. Some of the things I have seen would have made me sick two years ago. Now, no. But I can never be hardened to the thought that the poor lad in question had all the hopes and dreams of the rest of us, and perhaps a mother or a wife or a sweetheart watching the mail box every day. What a rude shock must be the news that finally comes of him! What everyone thinks he knows from reading and hearing takes on a new reality when you see. But, whatever started me on this? This is a heck of a birthday letter! Please excuse it. I am really not depressed. I know that these things must be. I only hope that those who make the peace remember what price was paid for it, and they make it stick. $^{113}$

112 Anna Young to John Mueller, February 15, 1945, Mueller Collection.

${ }^{113}$ Mueller to Mrs. George Hores, April 15, 1945, Mueller Collection. 
Even for a priest, coping was difficult. When confronted with the totality of combat, it seems that soldiers relied on the only things afforded them in the foxholes - their faith and one another. But even this was not always enough. It must not be forgotten that examples abound of men who simply buckled under the weight of the war. Even some Americans were overcome by what they had seen. Roy Cashdollar flew thirty-five bombing missions over Germany. He was shot down over France and was smuggled back to England through the French resistance. After returning from one particular bombing raid, he noticed that the pilot was extremely rattled: "I watched him. He just stepped into a propeller.",114

\section{Conclusion}

When the American soldier entered the battlefield he left much of his former identity behind him. The universal experiences of the environments, fear and uncertainty, killing and death, and methods of coping, ushered in a new world where the common denominator was the humanity of the individual. In the soldier narratives quoted above, nationality, ethnicity, and cultural differences are overshadowed by a common humanity. The West Virginia soldiers did not write about their lives in combat as Appalachians or Americans, they wrote as human beings. The myth of the uniquely violent mountain man is destroyed when comparing the accounts of West Virginians with those of other soldiers. In fact,

\footnotetext{
${ }^{114}$ Roy Clem Cashdollar interview by Tory McMahan, November 29, 2004, Chester, WV, WVVP.
} 
the soldier narratives go a long way in deconstructing the claim that any culture can fashion an individual who is inherently different from any other. The experience of nations demonstrates that similar conditions in battle evoke similar responses in soldiers. The end result is a loss of ideology and the destruction of most preconceptions men have before they enter combat. Dr. Richard A. Gabriel, in his study of psychiatrics and modern war proclaims that a loss of ideology is the least concern a battle-tested soldier must endure. Gabriel argued, "A historical review of psychiatric collapse in battle shows that no matter how well trained the soldiers . . . no matter how motivated the soldier, men under fire will succumb to the stresses and strains inflicted upon their psyche by the horribly destructive environment of the battlefield." 115 The soldiers themselves were the first to comprehend this claim. Here are the words of one mountaineer:

I entered the army with high hopes and still greater aspirations. I was a member of that generation of frustrated, heroic, pigheaded youth which laid in the gutters, wallered and slept in mud, snow, and rain actually thinking we were accomplishing something for our home and nation - for democracy. I dreamed of returning a conquering hero. I wanted to help preserve those freedoms so many were dying for. As I see it now - all was in vain. While helping to protect those many aspects of our security, our freedom, and of our peace. I lost something more vital than any hypocritical peace could ever mean to a bunch of money hungry gluttons, flag-waving, patriotic boosters at home. I lost my peace of mind, my own confidence in our government, and worst of all, I learned to doubt God. My doubt in the existence of a God and a Faith, which had been driven into me since I was old enough to distinguish between right and wrong, good and bad, drove me to

\footnotetext{
${ }^{115}$ Richard A. Gabriel, The Painful Field: The Psychiatric Dimension of Modern War (New York: Greenwood Press, 1988), 2.
} 
committing acts that only now do I realize and feel I am suffering for. The sword and the metallic thunder of the cannon made me conclude that there were more powerful things here on earth, than even my own blind faith. Now I wish I had remained blind, absurd, yet quite believable. ${ }^{116}$

Yet again, the loss of identity is often rejoined irrespective of nationality, as seen by this German example:

You are my witness that I never wanted to go along with it, Because I was afraid of the East, in fact of war in general. I have never been a soldier, only a man in uniform. What do I get out of it? What do the others get out of it? We who are playing the walk-on parts in this madness incarnate? What good does a heroes' death do us? ${ }^{117}$

The misguided ideals that brought men to the battlefields of World War II offered them no comfort when the fighting began, as the combatants were well aware.

No one can tell me any longer that the men died with the words "Deutschland" or "Hail Hitler" on their lips. There is plenty of dying, no question of that, but the last word is "mother" or the name of someone dear, or just a cry for help. ${ }^{118}$

On the other side of the world, the Japanese felt the same way: "There's not one soldier who ever died saying, 'Long live the Emperor!' I was with hundreds of men when they died."119 According to another Japanese veteran, "the only one

116 Account of Lloyd Kennedy, WWII Records, WVARHC.

${ }^{117}$ Schneider and Gullans, Last Letters, 46.

118 Schneider and Gullans, Last Letters, 50.

${ }^{119}$ Cook and Cook, Japan, 35. 
who wept at the actual news of Japan's defeat was the commander. I listened to the news laughing. I could hardly contain myself. I'd live!"120

The similar theme of disillusionment in all of these narratives is unmistakable. All over the world, millions of men mistakenly fought under the belief that their people were inherently superior and their enemies were inherently inferior. Tragically, it took the battlefield experiences and war narratives to demonstrate the myth of unique "cultural otherness." It was a terrible price to pay to gain the understanding that people are basically the same. Some of the mountaineers recognized this right away. William Wintz, of East Bank, WV, understood that West Virginians were not exceptionally different than any other Americans. He realized that "some people have tried to prove that West Virginians were better soldiers than anybody else. I disagree with that. They were good soldiers, but when you got in a unit and tried to become a hero and do something on your own, you didn't last long. ... You did your part and everyone else did their part. I had never seen one incident where one section of the country was better than others." ${ }^{121}$ Another mountaineer, Elmer Hendershot took the concept a step further. With an eye on the approaching Cold War, he declared that Americans were not so different from other nationalities. He stated that "there can't be too much difference between the people of Russia and the people of the United States. As long as this feeling prevails there is not likely to be another

${ }^{120}$ Cook and Cook, Japan, 280.

${ }^{121}$ William Wintz interview by Catherine Davis, February 17, 2002, East Bank, WV, World War II Papers and Interviews, WVDCH. 
war." ${ }^{122}$ Finally, are the thoughts of Jack Kieffer who remarked that the war taught him that perceived inherent differences based on stereotypes are trumped by our common humanity:

I've found that if you don't break it down to understand our fellow man enough because he's got a foreign language, looks different, and dresses different and all this. But when you get in the Marines and you begin to patronize with everybody. They're all a little different from New York, Kentucky, or somewhere and there's something about each one of them that you find are all alike ... there's toleration. ${ }^{123}$

122 Account of Elmer Hendershot.

123 Jack Kieffer interview. 


\section{Conclusion}

\section{From Humans to Stereotypes}

In December 1941, scores of young men joined the military eager to get away from home and join FDR's Arsenal of Democracy. In 1945, those who survived the conflict returned home with an equal if not greater enthusiasm than that when they departed. Herbert Dale couldn't wait to get home. "I was looking

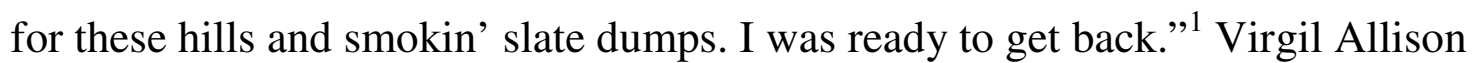
quietly made his way back to the Appalachian Mountains. "My last contact with the Army was on February 23, 1946, at Camp Atterbury, Indiana, where I received my honorable discharge and immediately started thumbing to my home town which is in Chester, West Virginia."” Jack C. Birkhimer was discharged in Maryland on November 16, 1945. "After spending a few wild days in Washington DC, and letting off steam, I went home. . . to rest my weary bones." ${ }^{, 3}$ Malcolm Campbell found homecoming difficult to describe "Arriving in the United States

\footnotetext{
${ }^{1}$ Herbert Dale Stover Interview by Matt Stover, November 19, 2004, Eccles, West Virginia.

${ }^{2}$ Account of Virgil Allison, World War II Records, West Virginia War History Commission Records (hereafter cited at WVWHCR), West Virginia and Regional History Collection, Morgantown, West Virginia (hereafter cited as WVARHC).

${ }^{3}$ Account of Jack C. Birkhimer, World War II Records, WVARHC.
} 
was a rather queer feeling down deep inside that is hard to write on paper, but only the ones that were over there knows."

For some, returning would present another challenge. Before his discharge, Charles Godwin admitted to a friend that rejoining civilian life would not be easy. "It will take time to readjust." The war left an indelible imprint on everyone who fought in it and without any proper government or military apparatus to help them deal with any psychological trauma, veterans did what they could on their own. "If I had come home and sat around and thought about it all the time, I would have went nuts. ${ }^{\prime 6}$ Men like Steve Riffon, however, could not help but to think about their wartime past. "Oh, you can never forget about it. Not a day goes by that I don't think about what happened over there. When you fight like that and have people die, it's not something you ever forget about. You can never get away from it all. It never leaves you."

Wives of the World War II veterans speak more freely of the post traumatic stress syndrome that so many men suffered. "It was a time of joy when they got back and it was a time of sadness because there was a lot of rehabilitation they had to do mostly on their own. Some could adjust and some couldn't. Some of the boys adjusted and some of the boys didn't adjust, could not adjust. Some of them became alcoholics." Betty Blume's words remind us that for thousands of men the

\footnotetext{
${ }^{4}$ Account of Malcolm Lyon Campbell, World War II Records, WVARHC.

${ }^{5}$ Charles Godwin to Bryan Hamilton, January 16, 1944, WVARHC.

${ }^{6}$ Junior L. Scott interview by Elisha Scott, April 19, 2004, Pinch, WV, WVVP.

${ }^{7}$ Steve Riffon interview.
} 
war continued on in their minds long after the firing had ended. "There weren't any rehab. If you didn't adjust you'd go to your local doctor and talk with him and he'd give you some sleeping pills and he'd tell you to go home and take some pills and go to bed. That's about what it amounted to." ${ }^{\prime 8}$ Even years later when an interviewer asked Wallace Shatzer if we was wounded during combat, he simply responded, "Not visibly.",

Unfortunately, the United States military had no real organizational structure to deal with post-traumatic stress endured by numerous veterans. Psychiatric breakdowns of soldiers during wartime had been a problem for the military dating back to the Civil War. Surgeons who dealt with psychiatric cases in the Civil War led to the field of neurology in the United States, but progress towards treating soldiers and veterans remained in an infant state. ${ }^{10}$ During World War I, Allied physicians mistakenly treated shell shock as though it was caused by concussive effects to the brain during artillery shelling. Men who broke down were either seen as suffering from a physical problem or assumed to be of weak character. In the Second World War, psychiatrists were hired by the military to screen enlistees for battle readiness, but their efforts were in vain as the rate of

\footnotetext{
${ }^{8}$ J.C. Blume, Betty Blume, and Evelyn Estep interview by Ashton N. Critchley, April 27, 2006, Fayetteville, WV, WVVP.

${ }^{9}$ Wallace M. Shatzer Interview by Kim Bailey and Thomas Luria, November 7, 2004, Morgantown, WV.

${ }^{10}$ Richard A. Gabriel, The Painful Field: The Psychiatric Dimension of Modern War (New York: Greenwood Press, 1988), 123.
} 
psychiatric casualties were double that of World War I. ${ }^{11}$ Even so, the military failed to provide any medical or psychiatric treatment for veterans after the war. Instead, the military concentrated its efforts on aiding soldiers during the war so that those adversely affected by modern combat could resume their military duties as soon as possible. Once the conflict ended, soldiers were on their own. Serious treatment for veterans did not arrive until after the Vietnam War. ${ }^{12}$ By the 1980s, nearly forty years after the end of World War II, veterans were able to seek psychiatric help for dealing with trauma. After many years, thousands of veterans from the "greatest generation" finally found some help in Veterans hospitals around the country. ${ }^{13}$

A significant number of veterans, particularly those who saw no combat, chose to focus on positive memories when recalling their military service in the war. "I got the experience of going around the world and seeing things. My over all ability to know what was going on in the world. But, it was good that I got out of my West Virginia surroundings for a while." ${ }^{14}$ Still others enjoyed the fanfare of victory. "People respected what the American soldier did. You were a hero. If you walked into a bar, someone bought you a drink. For a few years businessmen would ask if you were in the service ... they would knock off some when I bought

\footnotetext{
${ }^{11}$ Ibid., 126-128.

12 Theodore Nadelson, Trained to Kill: Soldiers at War (Baltimore: Johns Hopkins University Press, 2005), 90-91.

${ }^{13}$ Ibid., 97-98.

${ }^{14}$ Ira Dupey Lilly Interview by Meghan Lilly and Jaime Filipek, November 29, 2004, Orlando, Florida.
} 
stuff. " ${ }^{15}$ For Junior Gordon Arnold, who worked in the coal mines after the war, the military experience defined his masculinity. "It will make a man out of you. It'll either make you, or break you. You either stand up and be counted, or you're gone." ${ }^{16}$ And some view their service as a great positive moment in their lives. "Would I do it again?" Nick Oliver remarked, "Yes, in a heartbeat. When the Vietnam War broke out if I could've, I would've joined again. When the Persian Gulf broke out I thought, “Wow, if I was just young again.”,17

If veterans wanted to focus on something truly positive, they needed look no farther than the GI Bill. The impact of this piece of legislation is difficult to overstate. A few historians have even called it the most important bill of the last century and a "mid-twentieth century Bill of Rights." ${ }^{18}$ But many veterans did not realize it to be so at first. Coming from a Depression torn society many soldiers shared considerable concern about the state of the economy when they rejoined American society. No one knew for sure how the economy would hold up after demobilization. War plants were closing all across the nation as the government cancelled contracts and a few economists predicted a return to tough times. ${ }^{19}$ There was reason for apprehension in West Virginia as well. The powerful coal

${ }^{15}$ William Schnupp Interview by Matthew Schnupp, December 15, 2004, Wheeling, WV. 16 Junior Gordon Arnold Interview by Jackie Ayres, November 9, 2004, Morgantown, WV.

${ }^{17}$ Nick Oliver Interview by Ashley Strickler and William Shalhoub, November 16, 2004, Morgantown, WV.

${ }^{18}$ Glenn Altschuler and Stuart Blumin, The GI Bill: The New Deal for Veterans (Oxford: Oxford University Press, 2009), 3.

${ }^{19}$ Lee Kennett, G.I.: The American Soldier in World War II (Norman: University of Oklahoma Press, 1997), 230-231. 
industry had begun to see a renewal of labor struggles as a major strike wave coursed through the coal towns. Additionally, the increasing mechanization of the coal industry in the decade following the war would lead to thousands of men being replaced by machines. ${ }^{20}$ The machines would stay and the men would have to go. One soldier pondered the probability. "Perhaps you would rather settle down in West Virginia," he wrote to his wife, "but I am beginning to think it may be hard to get work there. ${ }^{, 21}$

While economic instability for West Virginia loomed on the horizon, the GI Bill gave a considerable jump start to returning soldiers. Within ten years of the war, 2,232,000 veterans had attended college on the GI Bill, often making them the first individuals in the history of their families to earn a college education. ${ }^{22}$ "Everybody then was taking advantage of the GI Bill of Rights," John Mangano remembered, "Everybody was going to the university. Shit, the dumbest guys that you knew were coming out with degrees, all kinds of degrees." ${ }^{23}$ It opened up higher education to the lower classes who would have never been able to attend a college without the legislation. Jewish and Catholic veterans were also able to enter campuses in unprecedented numbers. One Catholic priest even remarked that

\footnotetext{
${ }^{20}$ For postwar turbulence in the coal industry, see The Charleston Gazette, March 2, 1945; March 10, 1945; March 13, 1945; and March 17, 1945.

${ }^{21}$ Patrick Ward Gainer to his wife, August 26, 1945, Patrick Ward Gainer Collection, WVARHC.

${ }^{22}$ Keith W. Olson, The GI Bill, the Veterans, and the Colleges (Lexington: University Press of Kentucky, 1974), 43.

${ }^{23}$ John Mangano interview by John Gianola, April 15, 2004, Sabraton, WV, WVVP.
} 
the two most important events in the history of American Catholicism were the Second Vatican Council and the GI Bill. ${ }^{24}$

The bill also helped many GIs get their first home. The statistics are actually quite remarkable. A study in 1984 revealed that nine out of ten World War II veterans owned their own home and over half had paid off their mortgages. ${ }^{25}$ Around 8.3 million veterans received unemployment payments provided by GI Bill as "readjustment allowances." Approximately four million were granted a VA-guaranteed loan to finance a home, farm, or business. In all, seventy-eight percent of all veterans of the Second World War accepted benefits from the GI Bill. ${ }^{26}$

Just like in wartime conditions, veterans also helped one another. The Stuart family used money from the GI Bill, along with help from some other GIs who owned a lumber yard, to buy land and build a house near Morgantown, West Virginia. Stuart also used the GI Bill to help finish up his education. He earned a Ph.D. in Horticulture from West Virginia University and later returned to WVU to teach. ${ }^{27}$ Edwin Berry also took advantage of the GI Bill. After the war, he returned to Huntington, worked at the Post Office like his father, and used the GI Bill to finish his degree at Marshall and buy a house. ${ }^{28}$ Others used their money earned

${ }^{24}$ Suzanne Mettler, Soldiers to Citizens: The GI Bill and the Making of the Greatest Generation (Oxford: Oxford University Press, 2005), 53-54.

${ }^{25}$ Kennett, GI, 234.

${ }^{26}$ Altschuler and Blumin, The GI Bill, 8.

${ }^{27}$ Phoebe Stuart interview by Laura Stamm, April 26, 2006, Morgantown, WV, WVVP.

${ }^{28}$ Edwin C. Berry interview by Charles A. Nichols, Huntington, West Virginia, May 7 , 2002, World War II Interviews and Papers, WVDCH. 
during their service. William Wintz had saved one thousand seven hundred dollars by the end of the war and furnished his entire house with the money. ${ }^{29}$ One returning mountaineer simply said, "Everything had changed. There were more automobiles, more jobs." ${ }^{30}$

Numerous GIs enjoyed a measure of prosperity after the war, but many had to leave West Virginia in order to find it. Lester Hudson returned to West Virginia after the war and couldn't find work. He moved to Akron to work in a rubber factory. ${ }^{31}$ Ira Lilly started a trucking business after the war and became very successful, but he needed to move to Florida in order to make the business work. ${ }^{32}$ All over Appalachia people were leaving to find work elsewhere. Between 1940 and 1960 around seven million Appalachians left the region and flooded cities such as Cincinnati, Dayton, Akron, and Chicago. Akron, Ohio hosted so many mountaineers it came to be known as the "capitol of West Virginia."33 The natives of these cities often treated West Virginians like immigrants from a distant shore. City officials publicly debated on how to deal with the new "SAM Problem" (southern Appalachian migrants), and in Cincinnati and Chicago scholars hosted workshops in order to educate urbanites on how to relate to the "backward

\footnotetext{
${ }^{29}$ William Wintz interview.

${ }^{30}$ Haskell Moore Interview by Craig Arthur, November 28, 2004, South Charleston, WV, WVVP

${ }^{31}$ Lester R. Hudson Interview by Matthew Thorn, December 2, 2004, Point Pleasant, WV.

${ }^{32}$ Ira Dupey Lilly interview.

${ }^{33}$ Phillip Obermiller, Thomas Wagner, and E. Bruce Tucker,, eds., Appalachian Odyssey: Historical Perspectives on the Great Migration (Westport: Praeger Publishing Co., 2000), 4-9.
} 
mountaineers" who had "infested" their neighborhoods. The hundreds who attended these workshops were told that Appalachians were not like other Americans - they had different traits. ${ }^{34}$ In short, the Appalachian mountaineer was once again reentering the public consciousness, not as a human, but as a stereotype.

Due to deindustrialization and a sharp decline in the coal industry, millions had left the mountains for greener pastures. When workers left, local shops and restaurants also shut down, adding to the wave of out-migrants. Those who stayed behind were left with an economy that did not live up to national standards. In 1960, West Virginia's unemployment rate was more than double the national average and its per capita income was only seventy-five percent of the national average. ${ }^{35}$ When John F. Kennedy chose West Virginia as the launching pad for his presidential primary run, he travelled the state accompanied by journalists and scholars who wanted to know why West Virginians were so poor while living in a nation that had become so wealthy. The answers came in popular books such as the bestseller Yesterday's People, by Jack Weller and Harry Caudill's Night Comes to the Cumberlands. Even the Saturday Evening Post chimed in with a feature called "The Strange Case of West Virginia." 36 Their conclusion? West Virginians remained poor because of an inherent cultural otherness that prevented

\footnotetext{
${ }^{34}$ Ibid., 10-12.

${ }^{35}$ Otis K. Rice and Stephen Brown, West Virginia: A History (Lexington: University of Kentucky Press, 1991), 280.

${ }^{36}$ Ibid., 281-282; Jack E. Weller, Yesterday's People: Life in Contemporary Appalachia (Lexington: University of Kentucky Press, 1965); Harry M. Caudill, Night Comes to the Cumberlands: A Biography of a Depressed Area (Boston: Little Brown Press, 1963).
} 
them from properly adapting to a modern industrialized world. Despite the changing world around them, they were still isolated, rugged, and individualistic, clinging to traditionalism, familism, and fatalism. With the war twenty years gone, Appalachians were still seen as backward and the new twist on the old stereotype was to say that mountaineers were stuck in a "culture of poverty." In other words, the problem of Appalachia had nothing to do with flaws in the prevailing economic system of the United States; the problem was found in the inherent culture of the Appalachians themselves. ${ }^{37}$ Once again, they were given an old stereotype wrapped in a new package. When stereotypes are believed to be true, then some of the humanity is taken away from those who are being generalized. It seemed as though the scholars and journalists of America had not learned one of the most important lessons of the Second World War.

But what lessons can be learned from the experiences of West Virginians in World War II? First, the war narratives of mountaineers deeply broaden our understanding of stereotypes and Appalachian identity. While many West Virginians had never traveled away from home before the war, they still were very much in touch with mainstream American culture. They read many of the same books, listened to the same radio shows, and lived their lives in much the same way as rural Americans everywhere. As a result their experiences and recollections did not differ much from other Americans. The soldier narratives

\footnotetext{
${ }^{37}$ Dwight Billings and Kathleen M. Blee, The Road to Poverty: The Making of Wealth and Hardship in Appalachia (Cambridge: Cambride University Press, 2000), 8-17.
} 
also testify that geographic isolation does not necessarily lead to cultural isolation. Appalachian stereotypes are almost always contradicted by the behavior of Appalachians throughout their military service in the Second World War. The most obvious exception to this rule was when a few mountaineers selectively embellished hillbilly stereotypes in basic training because living up to the stereotype as a fighter suited their needs at the time. However, they did not behave as inherently violent and backward men once the actual fighting began. In battle, Appalachians reacted in a manner typical to all young men. In the specific case of mountaineers, their narratives were laced with the color of regional culture, a touch of Americanization, and broad strokes of general human emotion and contemplation. In the narratives, West Virginians often noted their love of music, they expressed deep appreciation for the physical environment around them, and they felt sympathetic towards those whom they found in poverty overseas. This does not suggest the existence of an "Appalachian otherness." Instead, it merely highlights the impact of regional geography and culture on any given individual. Second, we learn that a person's identity, and the stereotypes associated with their identity, can change based on where a person is more than who a person is. A young man from Charleston, West Virginia could plausibly transform from being seen as an urbanite at home, to a hillbilly in basic training, to an American cowboy overseas, to a subhuman enemy on the battlefield. Different stereotypes may apply to the same person over time, depending on the location of the individual. This reveals that stereotypes are almost always imposed by one group 
onto another group based on the preconceptions and knowledge (or lack thereof) of the group who is doing the stereotyping. When a soldier from New York met a West Virginian in boot camp, he may well have immediately conjured mental images of Appalachian stereotypes based on his own preconceptions. A French civilian who had never heard of a feuding redneck, by contrast, looked at a West Virginian and only recognized American stereotypes. In both cases, the behavior of the individual and their own personal identity had little to do with how they were perceived.

Finally, this study warns of the dangers of stereotyping. While Appalachians have been marginalized and stigmatized since the late nineteenth century, other groups have suffered even greater persecutions as a partial result of stereotyping. During World War II, stereotypes were used as justification for killings everywhere in the world. Mountaineers were one group accused of inherent violent behavior and cultural backwardness, but the groups who were the most guilty of mass violence and crimes against civilization were those groups such as the Nazis and the Japanese who utilized stereotypes for their own purposes. As the twenty-first century progresses, we must not forget the perils of using stereotypes to define culture. If further crimes against civilization are to be avoided, nations and ethnic groups need to recall our shared human traits more so than our cultural differences. Only when we fully embrace all that we share as a species can we know what is best for the prosperity, peace, and survival of the human race. 


\section{Bibliography}

\section{Manuscript Collections}

\section{Catholic Heritage Center Archives, Wheeling West Virginia}

Reverend Joseph J. Mueller Collection

West Virginia and Regional History Collection, Morgantown, West Virginia

Eisenhower Convocation Address Transcript

Glen L. Vaughn Collection

Patrick Ward Gainer Collection

Paul A. Adkins Collection

World War II Records

West Virginia Veterans Project

West Virginia War History Commission Records

West Virginia Division of Culture and History, Charleston, West Virginia

World War II Interviews and Papers.

\section{Newspapers}

Charleston Daily Mail

Charleston Gazette

Daily Athenaeum

Fairmont Times

Huntington Herald-Dispatch

McDowell Times

Morgantown Post

New York Times

Parkersburg Sentinel

Parkersburg Tribune

The West Virginian

Wheeling Intelligencer

Wheeling News Register 


\section{Books}

Adams, Michael C.C. The Best War Ever: America and World War II. Baltimore: John Hopkins University Press, 1994.

Allyn, David. Make Love, Not War: The Sexual Revolution, an Unfettered History. New York: Little, Brown, and Company, 2000.

Altschuler, Glenn and Stuart Blumin. The GI Bill: The New Deal for Veterans. Oxford: Oxford University Press, 2009.

Anderson, Karen. Wartime Women: Sex Roles, Family Relations, and the Status of Women During World War II. Westport: Greenwood Press, 1981.

Ayres, Thomas. A Military Miscellany. New York: Bantam Books, 2006.

Bauman, John F. and Thomas H. Coode, In the Eye of the Great Depression: New Deal Reporters and the Agony of the American People. Dekalb: Northern Illinois University Press, 1988.

Bartov, Omer. Mirrors of Destruction: War, Genocide, and Modern Identity. Oxford: Oxford University Press, 2006.

---------. The Eastern Front, 1941-1945: German Troops and the Barbarisation of Warfare. New York: St. Martin's Press, 2001.

Batteau, Allan W. The Invention of Appalachia. Tuscon: The University of Arizona Press, 1990.

Becker, Jane S. Selling Tradition: Appalachia and the Construction of an American Folk, 1930-1940. Chapel Hill: University of North Carolina Press, 1998.

Bertalan, Joseph. GI Joe Relives World War II. Morgantown: The Permutation Press, 1998.

Bidermann, Gottlob Herbert, Derek Zumbro, trans. In Deadly Combat: A German Soldier's Memoir of the Eastern Front. Lawrence: University Press of 
Kansas, 2000.

Billings, Dwight and Kathleen Blee, eds. Back Talk from Appalachia: Confronting Stereotypes. Lexington: University of Kentucky Press, 1999.

----------, The Road to Poverty: The Making of Wealth and Hardship in Appalachia. Cambridge: Cambridge University Press, 2000.

Blum, John Morton. V was for Victory: Politics and American Culture During World War II. New York: Harcourt Barce Jovanovich, 1976.

Brandt, Allan. No Magic Bullet: A Social History of Venereal Disease in the United States Since 1880. Oxford: Oxford University Press, 1987.

Bronner, Simon J., ed. Manly Traditions: Folk Roots of American Masculinities. Indianapolis: Indiana University Press, 2005.

Brown, Edwin L. and Colin J. David, eds. It is Union and Liberty: Alabama Coal Miners and the UMW. Tuscaloosa: University of Alabama Press, 1999.

Bull, Stephen and Gordon L. Rottman, Infantry Tactics of the Second World War. New York: Osprey Publishing, 2008.

Caudill, Harry M. Night Comes to the Cumberlands: A Biography of a Depressed Area. Boston: Little Brown Press, 1963.

Cesarini, David, ed. The Final Solution: Origins and Implementation. London: Routledge, 1994.

Chafe, William. The Unfinished Journey: America Since World War II. Oxford: Oxford University Press, 2003.

Chang, Iris. The Rape of Nanking: The Forgotten Holocaust of World War Two. New York: Penguin Books, 1997.

Churchill, Winston S. The Second World War, Volume 3: The Grand Alliance. New York: Bantam Books, 1962.

Cook, Taya Haruko and Theodore F. Cook, eds. Japan at War: An Oral History. New York: The New Press, 1992.

Cooke, Alistair. The American Home Front, 1941-1942. New York: Atlantic Monthly Press, 2006. 
Corbin, David Allan. Life, Work, and Rebellion in the Coalfields. Urbana: University of Illinois Press, 1981.

Day, John F. Bloody Ground. New York: Doubleday, 1941.

DeStasi, Lawrence, ed. Una Storia Segreta: The Secret History of Italian American Evacuation and Internment During World War II. Berkley: Heydey Books, 2003.

Dower, John W. War Without Mercy: Race, Power, and the Pacific War. New York: Pantheon Books, 1986.

----------. Embracing Defeat: Japan in the Wake of World War II. New York: The New Press, 1999.

Ellis, John. The Sharp End: the Fighting Man in World War II. New York: Charles Scribner's Sons, 1980.

Evans, Richard. Rereading German History, 1800-1996. London: Routledge, 1997.

Ferguson, Niall. The War of the World: Twentieth Century Conflict and the Descent of the West. New York: Penguin Books, 2006.

Fest, Joachim. Inside Hitler's Bunker: The Last Days of the Third Reich. New York: Farnqr, Straus, and Giroux, 2004.

Fritz, Stephen G. Frontsoldaten: The German Soldier in World War 2. Lexington: University Press of Kentucky, 1997.

Fry, Michael. The Scottish Empire. Edinburgh: Tuckwell Press, 2001.

Fuchida, Mitsuo and Masatake Okumiya. Midway: The Battle that Doomed Japan. New York: Bluejacket Books, 2001.

Fussell, Paul. The Boys' Crusade: The American Infantry in Northwestern Europe, 1944-1945. New York: The Modern Library, 2003.

---------. The Great War and Modern Memory. Oxford: Oxford University Press, 1975.

Wartime: Understanding and Behavior in the Second World War. 
Oxford: Oxford University Press, 1989.

Gabriel, Richard A. The Painful Field: The Psychiatric Dimension of Modern War. New York: Greenwood Press, 1988.

Gammer, Moshe. The Lone Wolf and the Bear: Three Centuries of Chechen Defiance of Russian Rule. Pittsburgh: University of Pittsburgh Press, 2006.

Gibney, Frank, ed., Senso: The Japanese Remember the Pacific War. New York: Little, Brown, and Company, 1995.

Goedde, Petra. GIs and Germans: Culture, Gender, and Foreign Relations, $1945-$ 1949. New Haven: Yale University Press, 2003.

Greenfield, Kent Roberts, Robert R. Palmer, and Bill I. Wiley. The United States Army in World War II: The Army Ground Forces and the Organization of Combat Troops. Washington D.C.: Historical Division, Department of the Army, 1947.

Hanson, Victor Davis. Carnage and Culture: Landmark Battles in the Rise of Western Power. New York: Anchor Books, 2002.

---------. The Soul of Battle: From the Ancient Times to the Present Day, How Three Great Liberators Vanquished Tyranny. New York: Anchor Books, 2001.

Harkins, Anthony. Hillbilly: A Cultural History of an American Icon. Oxford: Oxford University Press, 2004.

Hess, Gary R. The United States at War, 1941-1945. Illinois: Harlan Davidson, Inc., 2000.

Hicks, Melinda and C. Belmont Keeney. Defending the Homeland: Historical Perspectives on Radicalism, Terrorism, and State Responses. Morgantown: West Virginia University Press, 2007.

Hohn, Maria. GIs and Frauleins: The German-American Encounter in 1950s West Germany. Chapel Hill: University of North Carolina Press, 2002.

Ienaga, Sabura. Japan's Last War: World War II and the Japanese, 1931-1945. New York: Pantheon Books, 1978.

Inscoe, John C. Mountain Masters: Slavery and the Sectional Crisis in Western 
North Carolina. Knoxville: University of Tennessee Press, 1989.

Jackson, Carlton. A Social History of the Scotch-Irish. New York: Madison Books, 1993.

Jeffries, John W. Wartime America: The World War II Home Front. Chicago: Ivan R. Dee, 1988.

Keefer, Louis E. Scholars in Foxholes: The Story of the Armored Specialized Training Program in World War II. Jefferson: McFarland and Company, 1988.

Keegan, John. The Second World War. New York: Penguin Books, 1989. , The Face of Battle. London: Viking Press, 1976.

Kennett, Lee. G.I.: The American Soldier in World War II. Norman: University of Oklahoma Press, 1997.

Kuhl, Stevan. The Nazi Connection: Eugenics, American Racism, and German National Socialism. Oxford: Oxford University Press, 1994.

Lewis, Ronald L. Black Coal Miners in America: Race Class, and Community Conflict, 1780-1880. Lexington: University Press of Kentucky, 1987.

-------- and Ken Fones-Wolf, eds. Transnational West Virginia: Ethnic Communities and Economic Change, 1840-1940. Morgantown: West Virginia University Press, 2002.

Transforming the Appalachian Countryside: Railroads, Deforestation, and Social Change in Appalachia, 1880-1920. Chapel Hill: University of North Carolina Press, 1998.

Linderman, Gerald F. The World Within War: The Americans' Combat Experience in World War II. New York: The Free Press, 1997.

Litvin, Nikolai, Stuart Britton, trans. 800 Days on the Eastern Front: A Russian Soldier Remembers World War II. Lawrence: University Press of Kansas, 2007.

Longmate, Norman. The GIs: The Americans in Britain, 1942-1945. New York: Charles Scribner's Sons, Inc., 1975. 
Malia, Martin. The Soviet Tragedy: A History of Socialism in Russia, 1917-1991. New York: The Free Press, 1994.

Mettler, Suzanne. Soldiers to Citizens: The GI Bill and the Making of the Greatest Generation. Oxford: Oxford University Press, 2005.

Miller, Donald L. The Story of World War II. New York: Simon and Schuster, 2001.

Moniushko, Evgenii D., Oleg Sheremet, trans. From Leningrad to Hungary: Notes Of a Red Army Soldier, 1941-1946. New York: Taylor and Francis Group, 2005.

Moore, Christopher Paul. Fighting For America: Black Soldiers - The Unsung Heroes of World War II. New York: One World Books, 2005.

Muller, Rolf-Dieter, Gerd R. Ueberschar, eds. Hitler's War in the East, 19411945: A Critical Assessment. New York: Berghahn Books, 2002.

Nadelson, Theodore. Trained to Kill: Soldiers at War. Baltimore: Johns Hopkins University Press, 2005.

Obermiller, Phillip, Thomas Wagner, and E. Bruce Tucker, eds. Appalachian Odyssey: Historical Perspectives on the Great Migration. Westport: Praeger Publishing, 2000.

O'Brien, John. At Home in the Heart of Appalachia. New York: Anchor Books, 2001.

Olson, Keith W. The GI Bill, the Veterans, and the Colleges. Lexington: University Press of Kentucky, 1974.

Parillo, Mark P., ed. We Were in the Big One: Experiences of the World War II Generation. Wilmington: Scholarly Resources, Inc., 2002.

Pringle, Heather. The Master Plan: Himmler's Scholars and the Holocaust. New York: Hyperion, 2007.

Reuth, Ralf Georg, Goebbels. New York: Harcourt, Brace, and Company, 1993.

Rice, Connie. Our Monongalia: A History of African-Americans in Monongalia County. Terra Alta: Headline Books, Inc., 1999. 
Rice, Otis and Stephen Brown. West Virginia: A History. Lexington: University of Kentucky Press, 1993.

Schaller, Mark and Christian Camdall, eds. The Psychological Foundations of Culture. London: Lawrence Erlbaum Associates, 2004.

Schneider, Franz and Charles Gullans, eds. Last Letters from Stalingrad. New York: William Morrow and Company, 1962.

Shapiro, Henry D. Appalachia on Our Mind: The Southern Mountaineers in the American Consciousness, 1870-1920. Chapel Hill: University of North Carolina Press, 1978.

Shogan, Robert. The Battle of Blair Mountain: The Story of America's Largest Labor Uprising. Boulder: Westview Press, 2004.

Simpson, Grant G., ed. The Scottish Soldier Abroad, 1247-1967. Edinburgh: Billings and Sons, 1992.

Smoodin, Eric. Regarding Frank Capra: Audience, Celebrity, and American Film Studies, 1930-1960. Durham: Duke University Press, 2004.

Spector, Ronald H. Eagle Against the Sun: The American War with Japan. New York: Vintage Books, 1985.

Spielvogel, Jackson J. Hitler and Nazi German: A History. New Jersey: Prentice Hall, 1996.

Stealey, John. The Antebellum Kanawha Salt Industry and Western Markets. Lexington: University of Kentucky Press, 1993.

Streets, Heather. Martial Races: The Military, Race, and Masculinity in British Imperial Culture, 1857-1914. Manchester: Manchester University Press, 2004.

Sullivan, Ken, ed. The West Virginia Encyclopedia. Charleston: West Virginia Humanities Council, 2006.

Terkel, Studs, ed. The Good War: An Oral History of World War II. New York: The New Press, 1994.

Thomas, Jerry Bruce. An Appalachian New Deal: West Virginia in the Great Depression. Lexington: University of Kentucky Press, 1998. 
Toynbee, Arnold J. A Study of History. Oxford: Oxford University Press, 1947.

Waller, Altina. Feud: Hatfields, McCoys, and Social Change in Appalachia. Chapel Hill: University of North Carolina Press, 1988.

Webb, James. Born Fighting: How the Scots-Irish Shaped America. New York: Broadway Press, 2005.

Weller, Jack E. Yesterday's People: Life in Contemporary Appalachia. Lexington: University of Kentucky Press, 1965.

Whisnant, David E. All that is Native and Fine. Chapel Hill: University of North Carolina Press, 1983.

Williams, John Alexander. Appalachia: A History. Chapel Hill: University of North Carolina Press, 2002.

Wynau, Neil A. The Afro-American and the Second World War. New York: Holms and Meier, 1976.

Ziegler, Philip. Soldiers: Fighting Men's Lives, 1901-2001. New York: Alfred A. Knopf, 2002.

\section{Articles}

Breed, Allan G. "VHL and the Hatfield and McCoys?" http://www.vhl.clinicahealth.com/comments.ph?sids07/04/061826223.

Gibson, Dai Sil Kim. “The Women's International War Crimes Tribunal on Military Sexual Slavery." http://www.twotigers.org.

Keefer, Louis E. "Ashford General Hospital: The Greenbrier Goes to War." Goldenseal. Charleston: Fall 1993: 46-54.

Keeney, C. Belmont. "A Republican for Labor: T.C. Townsend and the West Virginia Labor Movement, 1921-1932." West Virginia History. Volume 60: 2004-2006: 1-22.

Lewis, Ronald L. and Dwight B. Billings. "Appalachian Culture and Economic 
Development.” Journal of Appalachian Studies. Spring 1997: 3-34.

Robinson, B. A. "Japanese Sex Slavery Before, During, and After World War II." http://www.religioustolerance.org/sla_japa.htm.

"Hatfield-McCoy Feud Blamed on 'Rage' Disease." http://www.msnbc.com/id/17967965. 